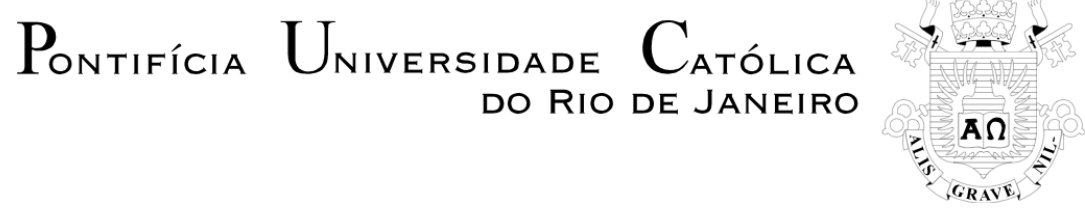

João Artur da Silva Souza

\title{
EXPERTISE EM TRADUÇÃO PARA LEGENDAGEM: processamento linguístico e segmentação textual
}

\section{Dissertação de Mestrado}

Dissertação apresentada ao Programa de Pósgraduação Estudos da Linguagem da PUC-Rio como requisito parcial para obtenção do título de Mestre em Letras/Estudos da Linguagem.

Orientadora: Profa. Erica dos Santos Rodrigues 


$$
\begin{array}{r}
\text { Pontifícia Universidade Católica } \\
\text { do Rio de Janeiro }
\end{array}
$$

João Artur da Silva Souza

\title{
EXPERTISE EM TRADUÇÃO PARA LEGENDAGEM: processamento linguístico e segmentação textual
}

\begin{abstract}
Dissertação apresentada como requisito parcial para obtenção do grau de Mestre pelo Programa de Pós-graduação Estudos da Linguagem da PUC-Rio. Aprovada pela Comissão Examinadora abaixo assinada.
\end{abstract}

\author{
Profa. Erica dos Santos Rodrigues \\ Orientador \\ Departamento de Letras - PUC-Rio
}

Prof. Eduardo Kenedy Nunes Areas

UFF

Prof. Igor Antônio Lourenço da Silva

UFU

Profa. Monah Winograd Coordenadora Setorial do Centro de Teologia

e Ciências Humanas - PUC-Rio

Rio de Janeiro, 30 de setembro de 2016. 
Todos os direitos reservados. É proibida a reprodução total ou parcial do trabalho sem autorização do autor, do orientador e da universidade.

\section{João Artur da Silva Souza}

Bacharel em Tradução pela PUC-Rio (2012), especializou-se profissionalmente na área da Tradução Audiovisual e Mídia e Acessibilidade, tendo traduzido diversos títulos para cinema e TV a cabo. Dedica-se à formação de novos profissionais e à pesquisa desde 2013. Atualmente, é professor da pós-graduação lato sensu da Universidade Estácio de Sá e tradutor e gerente de projetos da Little Brown Mouse, empresa especializada em serviços de tradução e acessibilidade para o cinema.

Ficha Catalográfica

Souza, João Artur da Silva

Expertise em tradução para legendagem: processamento linguístico e segmentação textual / João Artur da Silva Souza ; orientadora: Erica dos Santos Rodrigues. - 2016.

114 f. : il. color. ; $30 \mathrm{~cm}$

Dissertação (mestrado)-Pontifícia Universidade Católica do Rio de Janeiro, Departamento de Letras, 2016.

Inclui bibliografia

1. Letras - Teses. 2. Tradução audiovisual. 3. Psicolinguística. 4. Teoria do Garden-path. 5. Processamento linguístico. 6. Conhecimento Experto. I. Rodrigues, Erica dos Santos. II. Pontifícia Universidade Católica do Rio de Janeiro. Departamento de Letras. III. Título. 


\section{Agradecimentos}

Aos meus pais, por terem me ensinado que o caminho do conhecimento é o melhor que alguém pode trilhar, por acreditarem em mim e permitirem que eu seja quem eu sou.

À Luiza Frizzo Trugo, por toda inspiração, apoio incondicional e companhia em todas as etapas deste processo e da vida.

À professora Erica Rodrigues, por ter acreditado em mim e na minha proposta desde o começo, por ajudar a dar forma às minhas ideias e, principalmente, por não me deixar desistir.

À Nádia Frizzo Trugo e Luis Carlos Trugo (in memoriam), pela inspiração na carreira acadêmica através do exemplo, pelo apoio e todo o suporte que me permitiu ter tranquilidade nessa jornada.

À Sabrina Martinez, por ter me introduzido à Tradução Audiovisual, por confiar no meu potencial e ser uma excelente amiga e colega de trabalho.

A todos os participantes dos experimentos, que dedicaram voluntariamente seu tempo para colaborar com essa pesquisa.

A Ligia Sobral Fragano e Claudio Fragano da LBM pelo companheirismo, apoio e compreensão nos momentos de ausência que se fizeram necessários.

A todos os colegas da Dispositiva Produções, em especial Leilane Papa e Carolina Leal, pelo apoio e pela amizade que os anos de TAV trouxeram.

Ao Dream Team PUC e a todos os amigos que fizeram parte dessa jornada, compartilhando experiências e cedendo um ombro amigo.

Ao Marco Rachid, por mais de uma vez ter resgatado dados deste trabalho em HDs defeituosos, de maneira rápida e eficiente.

Aos professores Igor Lourenço, Eduardo Kenedy e Mercedes Marcilese pela disponibilidade para a leitura deste trabalho e particiação da banca.

À PUC e ao CNPq pelos auxílios e bolsas concedidos que permitiram me dedicar a esta pesquisa. 


\section{Resumo}

Souza, João Artur da Silva; Rodrigues, Erica dos Santos. Expertise em tradução para legendagem: processamento linguístico e segmentação textual. Rio de Janeiro, 2016, 114p. Dissertação de Mestrado Departamento de Letras, Pontifícia Universidade Católica do Rio de Janeiro.

Esta dissertação se insere na área de Psicolinguística e está em interface com os Estudos Cognitivos da Tradução. Examina o processo de segmentação textual de legendas no âmbito da investigação sobre a expertise tradutória em Legendagem, uma modalidade de Tradução Audiovisual subexplorada nesse aspecto. Considerou-se, em particular, a segmentação textual entre linhas de uma mesma legenda, uma habilidade com elevado grau de especificidade e indispensável a tradutores dessa área ao produzir uma redação que otimize o processamento nessas condições. Partindo de estudos sobre Expertise em Tradução (Shreve, 2006) e de pesquisas sobre processamento de sentenças, com foco particular na chamada Teoria do Garden-Path (Frazier \& Fodor, 1978), foram concebidos dois experimentos envolvendo tradutores aprendizes e experientes, com vistas a avaliar o desempenho dos dois grupos no processo de segmentação textual (experimento 1) e revisão de segmentações (experimento 2), nos dois casos com legendas em Português. Os paradigmas com alta validade ecológica, cujas tarefas experimentais eram compostas de fases reais do trabalho de profissionais da área, foram desempenhados em um software específico de legendagem. Os resultados do experimento 1 indicaram um desempenho superior do grupo de tradutores experientes, o que foi confirmado no experimento 2 , favorecendo as hipóteses dos autores de que i) a experiência é fator relevante no processo de segmentação de legendas; ii) tradutores experientes são sensíveis a segmentações que podem comprometer a leitura (sentenças do tipo garden path). As contribuições desta pesquisa são: a caracterização preliminar da expertise em tradução para legendagem e o aprofundamento da discussão sobre a TGP.

\section{Palavras-chave}

Tradução Audiovisual; Psicolinguística; Teoria do Garden-Path; Processamento Linguístico; Conhecimento Experto 


\section{Abstract}

Souza, João Artur da Silva; Rodrigues, Erica dos Santos (Advisor). Expertise in Subtitling: language processing and text segmentation. Rio de Janeiro, 2016, 114p. MSc. Dissertation - Departamento de Letras, Pontifícia Universidade Católica do Rio de Janeiro.

This work is an effort in the Psycholinguistics area and it is interfaced with that of Cognitive Translation Studies. It examines the process of textual segmentation of subtitles in the research on translation expertise in subtitling, an under investigated Audiovisual Translation mode in this regard. We consider, especially, the textual segmentation between lines of the same subtitle, a highly specific and indispensable skill that allow subtitlers to render their work in a way that optimizes the processing under these conditions. Based on studies of Expertise in Translation (Shreve, 2006) and language processing with focus on the GardenPath Theory (Frazier \& Fodor, 1978), we designed two experiments involving novice and experienced translators to evaluate the performance of both groups on the textual segmentation process (experiment 1) and segmentations revision (experiment 2); in both cases subtitles were in Portuguese. Experimental paradigms with high ecological validity, where the tasks were comprised of actual phases of professional work, were performed in a specific subtitling software. The results of experiment 1 showed superior performance of the professional group, which was confirmed in experiment 2, favoring the hypothesis of the authors that i) the experience is a relevant factor in the subtitle segmentation process; ii) experienced translators are sensitive to segmentations that can compromise reading (like garden path sentences). The preliminary characterization of expertise in subtitling and the new data added to the discussion on TGP are the main contributions this work achieves.

\section{Keywords}

Audiovisual Translation; Psycholonguistics; Language Processing; GardenPath Theory; Expert Knowledge 


\section{Sumário}

1. Introdução 11

1.1 Objetivos da pesquisa 12

1.2 Motivação 13

$\begin{array}{ll}1.3 \text { Relevância do tema e justificativas } & 14\end{array}$

2. Tradução audiovisual 17

$\begin{array}{ll}2.1 \text { Legendagem } & 19\end{array}$

2.2 Legendagem e Cognição 20

2.2.1 Legendagem e Cognição: estado da arte 22

3. Processos de leitura 33

3.1 Parsing sintático 35

3.2 Teoria do Garden Path 36

3.3 O processamento Good-Enough 39

4. Expertise e experiência em uma abordagem cognitiva da 42 tradução

4.1 Expertise e experiência 45

5. Experimentos 49

5.1 O problema 49

5.2. Experimento 1

5.2.1 Metodologia $\quad 55$

5.2.2 Resultados e discussão $\quad 51$

5.3. Experimento $2 \quad 71$

$\begin{array}{ll}\text { 5.3.1 Metodologia } & 71\end{array}$

$\begin{array}{ll}\text { 5.3.2 Resultados e discussão } & 77\end{array}$

6. Conclusões e considerações finais 88

Referências bibliográficas $\quad 92$

$\begin{array}{ll}\text { Anexo } & 102\end{array}$ 


\section{Lista de figuras}

Esquema dos componentes gerais do processo

Figura 1: de leitura, adaptado do esquema de Perfetti (1999, p.169)

$\begin{array}{ll} & \text { Exemplo de representação arbórea que orientaria } \\ \text { Figura 2: } & \text { segmentação das legendas, segundo proposta }\end{array}$ de Karamitroglou (1998)

Representação da tela utilizada para análise, em

Figura 3. que vemos a captura de tela do software Genius Subtitler e, no canto inferior direito, a imagem captura da webcam.

Figura 4: $\begin{aligned} & \text { Segmentação original das legendas do } \\ & \text { experimento } 1\end{aligned}$ 70

Figura 5: Segmentação das legendas do experimento 1 por 71 sujeito não experiente

Figura 6: $\quad \begin{aligned} & \text { Segmentação das } \\ & \text { sujeito experiente }\end{aligned}$

Figura 7: Desempenho de expertos e não expertos nos

Figura 8: Desempenho de expertos e não expertos nos 90

Figura 9: Desempenho de expertos e não expertos nos 


\section{Lista de gráficos}

Gráfico 1: $\quad$ Escore de desvios de segmentação

Gráfico 2: $\quad$ Tempo de execução da tarefa por

Gráfico 3: Tempo de execução da tarefa por aprendizes

Tempo de atenção dedicada às áreas de interesse $A 1$ (texto

Gráfico 4: original) e A2 (célula para segmentação textual e vídeo), pelos dois grupos de participantes, em segundos.

Gráfico 5: $\quad$ Tempo de duração da tarefa para

Gráfico 6: $\quad$ Tempo de duração da tarefa para participantes experientes

Gráfico 7: $\quad$ Média do tempo de duração da tarefa para os grupos 


\section{Lista de tabelas}

Tabela 1: Manipulação dos itens pelos 87

Tabela 2: $\quad$ Revisões de aprendizes 92

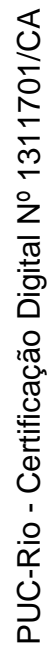




\section{Introdução}

O presente trabalho se insere na interface entre Psicolinguística e Estudos Cognitivos da Tradução, mais especificamente na subárea dos Estudos em Expertise por meio da investigação de habilidades específicas tidas como prérequisitos para tradutores para legendagem no processo de segmentação linguística entre linhas de legendas e seu respectivo impacto no processamento textual. Empreitadas interdisciplinares semelhantes têm se mostrado bastante produtivas na última década, principalmente em abordagens dos processos cognitivos subjacentes à tradução com vistas à caracterização de modelos que possam prover informações sobre nosso conhecimento da mente humana e a maneira como lidamos com aspectos envolvidos em processos mentais, como memória de trabalho, expertise tradutória e processamento linguístico. Além disso, tal abordagem tem o potencial de informar professores de tradução sobre a atividade tradutória a fim de que possam desenvolver estratégias de ensino mais refinadas e eficientes.

A Tradução Audiovisual e seu caráter intrinsicamente multimodal apresenta desafios ainda mais específicos para abordagens de natureza cognitiva e experimental ao demandar o processamento simultâneo e integrado de mais de um canal semiótico. Teorias e abordagens práticas sobre textos multimodais constituem um campo em franco desenvolvimento de refinamento teórico e metodológico (O’SULLIVAN, 2013). Neste trabalho, a questão da multimodalidade comparece em especial na avaliação do desempenho de aprendizes de tradução e tradutores experientes, que se diferenciam em termos da familiaridade com a presença simultânea dos vários canais semióticos (texto, som e imagem), e também no que tange à percepção desses dois grupos quanto ao papel da segmentação linguística das legendas na integração desses canais pelo público-alvo. 
Com este trabalho, busco responder a algumas questões norteadoras das pesquisas nas áreas a que me dedico como: será que os pressupostos que embasam o treinamento de profissionais de legendagem no que diz respeito à segmentação são de fato válidos? E, caso sejam, de fato, válidos, os direcionamentos embasados por esses pressupostos são refinados o suficiente para dar conta de fenômenos como o de sentenças garden-path? No que diz respeito à expertise, acredito que a seguinte discussão possa ser extremamente frutífera: em que medida à expertise em tradução para legendagem se aproxima ou distancia da expertise em tradução de modo geral? Estas questões, de modo geral, não apenas orientam o trabalho como são verdadeiramente motivadoras desta pesquisa.

Nas últimas duas décadas, empreitadas experimentais direcionadas exclusivamente ao processamento de legendas ou à caracterização da produção de traduções e o conhecimento experto de tradutores ganharam destaque e evoluíram paralelamente. A presente dissertação, em caráter provavelmente inédito, visa a integrar ambas as áreas supracitadas, como poderá ser observado nos próximos capítulos.

\section{1}

\section{Objetivos da pesquisa}

Devido ao caráter interdisciplinar da empreitada em que me lanço, ao aliar a pesquisa Psicolinguística, aos Estudos Cognitivos da Tradução, mais especificamente às pesquisas na área de expertise tradutório, organizo os objetivos da pesquisa da seguinte maneira:

1) Verificar, através de experimentos, em que medida o processo de segmentação textual em legendagem pode ser considerado reflexo de uma intuição linguística comum que orienta a leitura ou de expertise tradutória, ou seja, de habilidades adquiridas a partir da prática;

2) Avaliar como tradutores experientes e aprendizes, no processo de segmentação de legendas, lidam com os impactos da segmentação linguística para a integração da legenda ao vídeo ao avaliar processos 
atencionais por meio do tempo de dedicação a diferentes áreas de interesse pré-determinadas;

3) Investigar a sensibilidade de tradutores experientes e aprendizes a segmentações que podem induzir efeitos de garden path na leitura de legendas e os tipos de estratégias linguísticas empregadas pelos dois grupos na revisão dessas legendas visando a garantir seu processamento ótimo;

4) Verificar como um paradigma com alto valor ecológico, distanciando-se em certa medida dos experimentos tradicionais em Psicolinguística, pode ser, de fato, relevante e informativo.

\section{2}

\section{Motivação}

Esta pesquisa é motivada principalmente por questões práticas concernentes a minha experiência enquanto estudante de Tradução e professor de Tradução para Legendagem, de modo que considero conveniente apresentar meu locus enuntiationis.

Meu interesse pela pesquisa em Tradução Audiovisual advém, principalmente, de minha experiência na área. Em 2012, me formei bacharel em Tradução pela PUC-Rio; todavia, meu interesse pela Tradução Audiovisual antecede meu ingresso na universidade, em 2007. Até o momento, traduzi para legendagem pouco mais de 400 horas (agosto de 2016) de diferentes gêneros para cinema e televisão a cabo, como filmes, reality shows, entrevistas, shows, documentários, dentre outros. Também produzi, embora com menor regularidade, legendas para surdos e ensurdecidos e roteiros para Audiodescrição, Narração e Dublagem. Ao longo do meu trabalho como tradutor, me deparei inúmeras vezes com momentos em que questionei aquilo que me havia sido ensinado e era reforçado por manuais. Ao lecionar tradução para legendagem, a necessidade de me aprofundar no conhecimento teórico para transmiti-lo da maneira adequada e elucidar dúvidas, passei a problematizar ainda mais a questão da segmentação textual, muitas vezes motivado por questionamentos vindos dos alunos. Ao mesmo 
tempo, o contato constante com muitos colegas da área e a curiosidade pelas diversas formas de trabalhar de cada um me levaram a desenvolver um crescente interesse pelo que mais tarde vi estar estreitamente relacionado aos trabalhos desenvolvidos na área de expertise tradutória.

\section{3}

\section{Relevância do tema e justificativas}

Acredito que a presente pesquisa, por seu caráter interdisciplinar, tenha relevância para diferentes áreas, contribuindo, em graus dessemelhantes, para cada uma delas. Destaco aqui pontos que podem ser mais objetivamente observáveis, haja vista seu potencial de vir a lograr contribuição para alguma das áreas a que me dedico.

Para a Linguística e a Psicolinguística este trabalho é relevante pois:

i) apresenta determinadas estruturas sintáticas e as problematiza na medida em que discute características do processamento atrelado à segmentação interna dessas estruturas em português brasileiro à luz da Teoria do Garden Path;

ii) dadas as limitações inerentes à pesquisa em legendagem, principalmente no que diz respeito aos diferentes canais semióticos transmitidos em paralelo e aos aspectos técnicos específicos da modalidade, o presente trabalho é relevante pois colabora para o refinamento de métodos experimentais existentes ao propor um paradigma criativo para o estudo da legendagem com grande preocupação com a validade ecológica, reproduzindo fielmente contextos de atuação profissional (experimentos 1 e 2);

Ao dedicar esforços a estruturas do tipo garden path, que ocorrem em diferentes contextos e têm motivado inúmeras pesquisas sobre processos de leitura, este trabalho se justifica ao explorar tal tipo de sentença em condições menos usuais na literatura; no contexto da legendagem e no contexto da produção mediada pela revisão (vide experimentos 1 e 2) e não apenas na compreensão. 
A relevância desta pesquisa para os Estudos em Expertise refere-se principalmente:

i) à modalidade de tradução, neste caso a legendagem, cujo potencial ainda é pouquíssimo explorado;

ii) à proposta de aliar o embasamento teórico da Teoria do Garden Path e do método experimental como implementado na pesquisa psicolinguística ao método empírico-experimental adotado pelas pesquisas sobre o processo tradutório e a expertise.

É justificado também o estudo da tradução para legendagem sob a perspectiva da expertise, pois tais estudos até agora se debruçaram primordialmente sobre a tradução escrita, seja de textos literários ou técnico-científicos. A investigação de uma modalidade tradutória tão específica e com demandas aparentemente distintas pode vir a ampliar nosso conhecimento sobre o processos cognitivos envolvidos na tradução.

O presente trabalho se mostra também relevante para a Tradução para Legendagem:

i) ao fomentar os estudos sobre processamento de legendas, área que desperta muito interesse, mas carece de esforços organizados para a construção de um corpo de conhecimento, principalmente no Brasil;

ii) prover direcionamentos claros e objetivos que possam vir a ser integrados a manuais de legendagem e adotados por professores da área, contribuindo para a facilitação do ensino e a consequente melhora na dinâmica de trabalho de profissionais.

Nesta dissertação, conduzirei dois experimentos com o objetivo de caracterizar uma possível subcompetência tradutória específica ao ramo da legendagem ao verificar a capacidade de dois grupos, um de tradutores experientes e outro de aprendizes, em tarefas que simulam fidedignamente situações do cotidiano de tradutores da área. Trabalho com a hipótese de que a experiência em tradução para legendagem tem, sim, um fator determinante no desempenho experto, de modo que minhas previsões são de que o grupo formado por tradutores 
experientes terá um desempenho consistentemente superior ao dos aprendizes nos experimentos.

A presente dissertação está organizada da seguinte maneira: no capítulo 2, A Tradução Audiovisual, apresento de modo amplo este campo da tradução, alguns dos desafios inerentes a ele e o status das diferentes modalidades na atualidade. Em seguida, discorro em maior detalhes sobre a tradução para legendagem, foco desta pesquisa, e encerro o capítulo apresentando pesquisas em Legendagem com enfoque em cognição que possuem, em alguma medida, relação com esta pesquisa. No capítulo 3, Processos de Leitura, a primeira preocupação é a de conceituar esses processos de maneira ampla e, em seguida, caracterizá-los no contexto da legendagem e suas peculiaridades sob uma ótica psicolinguística. $\mathrm{Na}$ seção seguinte, apresento o parser, as hipóteses sobre seu funcionamento e a Teoria do Garden Path, que orienta este trabalho. Por último, demonstro como o problema central deste trabalho, a segmentação textual em legendagem, é abordado pelo viés da Psicolinguística informada pela Teoria do Garden Path. No capítulo 4, Expertise e Tradução, começo por apresentar de modo amplo as pesquisas em expertise e algumas das áreas relacionadas a ela. Em seguida, demonstro como pesquisadores vinculados aos Estudos da Tradução têm adotado essa abordagem em pesquisas empírico-experimentais sobre o processo tradutório. No capítulo 5, apresento em detalhes dois experimentos, sendo o segundo um piloto, empregados na investigação dos fenômenos concernentes à esta pesquisa. Para cada experimento, apresento uma discussão e conclusões parciais que, no capítulo seguinte, o de conclusões, são desenvolvidas à luz das bases teóricas propostas, indicando eventuais desdobramentos desta empreitada. 


\section{Tradução audiovisual}

Tradução Audiovisual é o termo usado para se referir à transferência de uma língua para outra dos componentes verbais que compõem obras e produtos audiovisuais. Filmes, programas de TV, peças teatrais, musicais, óperas, páginas da web e vídeo games são apenas alguns dos exemplos da vastíssima gama de produtos audiovisuais disponíveis que podem ser traduzidos.

Como o nome sugere, o "audiovisual" é composto de algo que pode ser ouvido (áudio) e visto (visual) simultaneamente. Todavia, o objetivo primário desse tipo de produto é ser visto, tanto é que "assistimos a" ou "vemos" um filme, série ou programa. No entanto, embora os códigos verbal e visual estejam, até certo ponto, intrinsecamente relacionados, a tradução desse material ocorre majoritariamente no nível verbal. E é exatamente por obras audiovisuais serem produzidas com o intuito de serem vistas e ouvidas em concomitância que sua tradução difere amplamente de obras impressas. Ilustrações, diagramas, gráficos e fotos apenas acompanham e, por vezes, enfatizam o conteúdo verbal. Já em obras audiovisuais, por outro lado, os conteúdos verbal e visual funcionam de maneira una a fim de criar um todo dotado de significado; obras audiovisuais são compostas de uma série de códigos que, em interação, produzem um efeito único. Mensagens verbais, por exemplo, podem ser transmitidas tanto acústica quanto visualmente. Se pensarmos num filme, é possível imaginarmos um contexto em que o espectador seja exposto não apenas às falas dos personagens e músicas cantadas, mas a uma série de informações escritas, como placas, bilhetes, letreiros e cartelas. Ademais, pode-se destacar a quantidade substancial de informação escrita sobre a própria obra na forma de créditos, como os nomes do diretor, dos produtores, elenco etc. Num outro plano, mas ainda relacionado aos canais acústico e visual, obras audiovisuais contém efeitos sonoros não verbais, sons ambientes, sons corporais (respiração, risada, choro etc) e música. Somam-se a isso expressões faciais de atores, gestos e movimentos, figurinos, penteados, maquiagem etc. Por último, não podemos esquecer da relevância do uso de cenários, da escolha de locações, do emprego de cores e efeitos especiais. A Tradução Audiovisual deve abarcar todos 
esses aspectos variados de conteúdo visual e verbal, levando em conta o fato de que a indissolubilidade dos códigos pode restringir o processo tradutório.

Produtos audiovisuais, geralmente, são desenvolvidos com o apoio de aparelhagem tecnológica, como câmeras e película, no caso dos filmes, e computadores e softwares específicos, no caso de websites e jogos. Da mesma maneira, obras audiovisuais podem ser consumidas através de diferentes meios tecnológicos; telas de cinema, aparelhos de TV, computadores e consoles de vídeo game, são alguns dos meios mais comuns. Todavia, nem toda forma de TAV pressupõe a presença de uma tela. Produções teatrais, principalmente musicais e óperas são exemplos de produtos audiovisuais caracterizados pela performance ao vivo. Em geral, essas obras são apresentadas em seu idioma de origem, enquanto o público acompanha a tradução através de libretos que também servem aos falantes do idioma em que a ópera é cantada, haja vista que as características interpretativas do gênero podem tornar a compreensão difícil. Neste caso, ocorre o que Jakobson (1959) caracterizou como tradução intralingual, em que não há transferência de código linguístico, mas de meio de transmissão, como ocorre também na Legendagem para Surdos e Ensurdecidos (LSE), modalidade de TAV com enfoque na acessibilidade. A tradução em teatros, no entanto, tem se beneficiado cada vez mais de avanços tecnológicos. As legendas agora são projetadas sobre o palco (surtitles), libretos digitais são disponibilizados nos encostos dos assentos do teatro, assim como aplicativos para tablets e celulares com transmissão de legendas.

As principais modalidades de tradução audiovisual são a legendagem e a dublagem. A Europa ocidental que, reconhecidamente sempre se mostrou como um ambiente fértil para o desenvolvimento teórico, prático e tecnológico da TAV, por exemplo, divide-se entre um bloco formado pelos países escandinavos e do Benelux, Grécia e Portugal que adota prioritariamente a legendagem, e outro formado pelos países conhecidos pela sigla em inglês "FIGS", França, Itália, Alemanha e Espanha, que adotam majoritariamente a dublagem. Avanços tecnológicos, questões culturais e políticas, para citar alguns pontos, todavia, têm tido papel importante na mudança do status de modalidades em diversos países. $\mathrm{O}$ Brasil, por exemplo, quando começou a importar conteúdo estrangeiro para exibição no cinema em meados da década de 1930 e, duas décadas mais tarde, na TV, optou pela legendagem, que além de ser a opção menos custosa era bem aceita 
pelo público-alvo. Todavia, com a expansão e a popularização dos meios de comunicação, uma lei que obriga a exibição de conteúdo dublado na TV aberta e altos índices de analfabetismo, a dublagem ganhou espaço no Brasil, consolidandose cada vez mais com avanços tecnológicos no começo dos anos 2000. Atualmente, o Brasil e a Alemanha configuram um caso muito interessante de coexistência de modalidades em que há grande aceitação tanto da dublagem quanto da legendagem. (SOUZA \& BAYREUTHER, 2015)

\section{1}

\section{Legendagem}

Legendas (subtitles) são "... o texto em idioma diferente das mensagens verbais da mídia traduzida reproduzido em uma ou mais linhas de texto escrito, em geral, no terço inferior da tela em sincronia com a mensagem original." (GOTTLIEB, 2001:87, tradução nossa ${ }^{1}$ ). Uma das principais características da legendagem em relação a outras modalidades de tradução é o resumo do texto-fonte, ou seja, do que é ouvido. As legendas podem ainda ser classificadas em "abertas", quando incorporadas ao vídeo em si ou "fechadas", quando é permitido ao espectador optar pela transmissão ou não das legendas, como em DVDs. A segunda realidade tem sido cada vez mais comum através de avanços tecnológicos como a transmissão de sinal digital de TV e serviços de streaming. Em festivais de cinema, o costume é de haver a projeção das legendas em tempo real logo abaixo da tela de exibição, muitas vezes em dois idiomas.

Legendas constituem um canal semiótico adicionado a posteriori a uma obra, por natureza, polissemiótica, ou seja, representam um fator que torna o processamento mais desafiador. Por isso, muito frequentemente, é necessário reduzir o conteúdo das falas, para que os espectadores tenham tempo para dedicar atenção aos diferentes elementos citados anteriormente que constituem o filme, sem deixar em segundo plano o objetivo principal, seja ele entretenimento, aprendizado etc. Não são poucos os teóricos (como KARAMITROGLOU, 1998, e IVARSON

\footnotetext{
${ }^{1}$ In the context of translation, and expressed in general and rather technical terms, subtitling consists in the rendering in a different language (1) of verbal messages (2) in filmic media (3), in the shape of one or more lines of written text (4), presented on the screen (5) in sync with the original verbal message (6).
} 
\& CARROL, 1998) que defendem uma quase "invisibilidade" das legendas, através de resumo textual e tempo de exibição reduzido, com o intuito de diminuir a poluição da imagem e facilitar a leitura do público. A fim de caracterizar a modalidade de tradução em foco nesta dissertação, destaco as estratégias mais comuns utilizadas na produção de legendas. Em primeiro lugar, há a redução de elementos que não alteram o significado do original, como repetições, pausas, hesitações, autocorreções etc. Em seguida, o apagamento de tabuísmos e gírias tendência cada vez mais restrita à televisão, em que os horários de exibição são determinados pela classificação indicativa das obras - e a homogeneização de dialetos e a simplificação de estruturas sintáticas, com o intuito de tornar as legendas mais facilmente apreensíveis no tempo, geralmente curto, de exibição, sem possibilidade de releitura, o que caracteriza a efemeridade do texto para legendagem. As estratégias supracitadas se coadunam às restrições espaçotemporais convencionalmente adotadas em legendagem, como a limitação de duas linhas, de 30 a 42 caracteres e tempo de exibição entre 1 e 6 segundos, como proposto por Diaz-Cíntas (2008), na chamada "six-second rule", em que se espera que o espectador médio leia duas linhas de texto de aproximadamente 37 caracteres cada, ou seja, 74 no total, confortavelmente em seis segundos. Dessa forma, teríamos uma velocidade média de leitura de 15 caracteres por segundo (cps) ou de 140 a 150 palavras por minuto ( $\mathrm{ppl}$ ), considerando palavras com, em média, 5 letras. Softwares profissionais são pré-configuráveis para auxiliar tradutores em suas tarefas, indicando legendas com velocidade de leitura elevada e/ou que extrapolam os limites de caracteres permitidos. Atualmente, os valores para velocidade média de leitura são mais altos, girando em torno de 15 cps e 18 cps.

\section{2}

\section{Legendagem e Cognição}

Como visto na seção anterior, a legendagem tem sido empregada desde a década de 1930 com o início do cinema falado de maneira a facilitar a distribuição de filmes produzidos nos Estados Unidos e na Europa. Nas décadas subsequentes, em consonância com o desenvolvimento tecnológico, ganhou outras funções e passou a ser empregada em outros contextos. Primeiro, como alternativa de baixo custo para a distribuição de conteúdo audiovisual quando comparada ao custo total 
da tradução e dublagem de uma obra, haja vista que a dublagem requer a contratação de atores, pelo menos um diretor e um técnico de gravação e diversas horas de estúdio. Segundo, após a popularização do DVD, tem-se tornado prática cada vez mais comum o emprego de obras audiovisuais como ferramenta de apoio no ensino de línguas estrangeiras. Alguns pesquisadores destacaram como filmes legendados podem ter um papel facilitador na aquisição lexical (e.g., D'YDEWALLE \& PAVAKANUN, 1995, 1997; D'YDEWALLE \& VAN DE POEL, 1999). Além disso, a legendagem é, de fato, a modalidade preferida de alguns públicos, a destacar-se o de pessoas com algum nível de bilinguismo, que permite a fruição das vozes originais dos atores, parte integrante da concepção de personagens (KOOLSTRA, PEETERS, \& SPINHOF, 2002). Por último, temos a legendagem intralingual, que tem sido empregada para fins de acessibilidade a pessoas surdas e ensurdecidas (LSE - Legendas para surdos e ensurdecidos) (DE LINDE \& KAY, 1999a, 1999b) e como ferramenta facilitadora da alfabetização e da aquisição de língua estrangeira (KOTHARI, 1998, 2000; KOTHARI \& TAKEDA, 2000).

Os avanços tecnológicos da década de 1990, dos quais podemos destacar a popularização dos computadores pessoais, da internet, das transmissões via cabo e do DVD, além de terem contribuído amplamente para o processo de globalização, colocaram a Tradução Audiovisual em evidência. Num período demasiadamente curto, criou-se uma demanda por profissionais com um novo perfil. A prática, agora em evidência, suscitou reflexões de toda sorte e, desde então, tem se desenvolvido sem mostrar sinais de fraqueza, apesar, inclusive, da recessão econômica enfrentada por muitos países a partir de 2010 e que ainda perdura em boa parte deles. Nesse cenário, todavia, o que chama atenção é o fato de, apesar da centralidade de seu papel sociocultural, a legendagem tenha recebido escassa atenção por parte da psicologia experimental e dos estudos em Mídia e Psicologia, tendo pouco sido desenvolvido no sentido de entender a maneira como obras audiovisuais legendadas são recebidas, assim como os processos mentais subjacentes envolvidos nesta atividade. O interesse pela área, no entanto, só veio a crescer de maneira regular com uma série de trabalhos a partir dos anos 2000 que têm retomado o hoje seminal Watching Subtitled Television - Automatic Reading Behavior (D'YDEWALLE ET AL., 1991). Nos anos subsequentes, Gery d'Ydewalle orientou vários estudos de 
processamento de obras audiovisuais legendadas e dubladas com base na psicologia experimental, originando o que hoje ficou conhecido como Escola Belga. Seus principais trabalhos são apresentados brevemente na sessão seguinte.

\subsection{1}

\section{Legendagem e Cognição: estado da arte}

Apesar da efusão recente de trabalhos na área, ainda restam muitas lacunas no conhecimento que temos sobre o processamento de obras audiovisuais legendadas, todavia, o pouco que se sabe é embasado por testes experimentais com objetivos diferentes, mas que, indiretamente, apresentam evidências compatíveis com as mesmas hipóteses. O exemplo mais evidente disso está em d'Ydewalle \& Gielen (1992), em que os autores relatam que indivíduos demonstram uma forte tendência a iniciar a leitura de legendas assim que elas são exibidas, mesmo quando não familiarizados com esse tipo de fonte de informação. Tal tendência se acentua quando o participante tem pouco ou nenhum conhecimento sobre a língua falada no filme ou quando há pouca redundância entre texto e imagens, de forma que as informações veiculadas pelas legendas tornam-se mais relevantes ao telespectador que, por sua vez, depende delas (D’YDEWALLE \& GIELEN, 1992; D'YDEWALLE \& PAVAKANUN, 1997; D'YDEWALLE, PRAET, VERFAILLE, \& VAN RENSBERGEN, 1991; D'YDEWALLE, VAN RESENBERGEN, \& POLLET, 1987; GIELEN, 1988).

Além disso, o desempenho na leitura de legendas e na consequente compreensão de obras audiovisuais legendadas parece estar intimamente ligado ao nível de familiaridade do telespectador com esse tipo de obra (D'YDEWALLE \& GIELEN, 1992). Em Perego e colaboradores (2010), os autores sugerem que o desempenho superior de alguns participantes de suas pesquisas poderia estar relacionado a diferentes níveis de refinamento de funções executivas, ou seja, o grupo de habilidades empenhadas no processo cognitivo orientado a uma meta interna determinada, como manutenção da atenção, memória de trabalho, inibição de informações distratoras e, principalmente, a capacidade de raciocínio abstrato. Tal hipótese, todavia, precisa ser investigada mais a fundo, inclusive experimentalmente. 
A eficiência assim como o automatismo associados ao aparente pouco esforço cognitivo para o processamento de legendas é condizente com pesquisas sobre leitura que têm demonstrado que esse processo pode se tornar parcialmente automático e fácil para adultos por conta de processos de aprendizagem. Embora a leitura exija uma série de processos perceptuais e habilidades cognitivas complexas, como o conhecimento de um determinado sistema de escrita, a capacidade de reconhecimento e decodificação de informação fonológica e conhecimento gramatical, por exemplo, graças ao aprendizado decorrente da prática da leitura, parte desses processos se torna automatizada. (PERFETTI \& MARRON, 1998; PERFETTI, 1999; PERFETTI, 2001; PERFETTI ET AL., 2005).

A maior parte das pesquisas sobre processamento cognitivo de legendas na década de 1990 teve como enfoque questões de alocação de atenção entre legenda e imagem. Em d'Ydewalle e De Bruycker (2007), temos a replicação de alguns comportamentos relatados na literatura, como i) a maior incidência de movimentos regressivos em comparação com a leitura normal e ii) uma menor duração de fixações em legendas ${ }^{2}$ (também em comparação com a leitura normal). Estas informações foram obtidas através de experimentos com rastreamento ocular, técnica cujo emprego na investigação do processamento da linguagem tem sido feito com crescente sucesso nas últimas duas décadas e visa a identificar o foco da atenção, e do consequente processamento de informação e a maneira como o fazemos. Nos paradigmas proporcionados por essa técnica, o participante, embora possua controle consciente sobre o comportamento tomado como variável dependente, o faz raramente, haja vista que tal comportamento é, em grande parte, involuntário. A técnica ainda é interessante por permitir ao experimentador que monitore o sujeito continuamente com baixa latência entre estímulo e resposta, permitindo que o processamento de unidades e fenômenos mínimos sejam investigados. Essas informações corroboram o fato de que ocorre uma troca constante de foco de atenção entre diferentes fontes de conteúdo (legendas e

\footnotetext{
${ }^{2}$ Movimentos regressivos são aqueles os olhos retomam informação na qual já se deteve anteriormente em vez de prosseguir o fluxo natural do processamento de determinado tipo de informação, da esquerda para a direita, na leitura em português, por exemplo. Fixações são períodos parcialmente estacionários com duração entre $200 \mathrm{~ms}$ e $300 \mathrm{~ms}$ que ocorrem entre sacadas; movimentos balísticos, voluntários ou reflexivos, que ocorrem, de modo geral, por volta de 4 vezes por segundo e têm duração de 10 a 100 milissegundos. (Richardson e Spivey, 2004/2007).
} 
imagem) e a hipótese dos autores de que telespectadores são capazes de ajustar a duração de fixações e retomar, sem maiores dificuldades, texto que já tenha sido processado a fim de atender a necessidades específicas de processamento e coerções do contexto. Destaco aqui o fato de que a relativa facilidade no comportamento de leitura observado por pesquisadores da Escola Belga (D’YDEWALLE ET AL., 1987, 1991; D’YDEWALLE \& VAN RENSBERGEN, 1989; KOOLSTRA \& BEENTJES, 1999) aliada a questões de eficiência de processamento (D'YDEWALLE \& DE BRUYCKER, 2007; D'YDEWALLE \& GIELEN, 1992) tem sido usado como embasamento para os achados recentes sobre o processamento de obras audiovisuais legendadas.

D’Ydewalle e De Bruycker (2007), todavia, não restringem seus achados à alocação de atenção e discorrem sobre padrões de leitura ao conduzirem experimentos com rastreamento ocular comparando o comportamento de alunos do $6^{\circ}$ ano e adultos assistindo a um programa em língua estrangeira com legendas. Embora não tenham encontrado diferenças significativas no comportamento ocular dos dois grupos, os autores destacam a ocorrência de um padrão de leitura mais regular para legendas com duas linhas de texto em oposição a legendas com apenas uma linha em ambos os grupos. A hipótese dos autores é que o conteúdo de legendas com duas linhas tem maior probabilidade de ser processado por conter mais informação que não pode ser inferida por outros canais semióticos, principalmente o visual, sugerindo que telespectadores tenham um comportamento adaptativo, dispensando maior atenção a legendas com conteúdo não redundante, por conseguinte, mais informativas para a compreensão.

Como apontado por Perego e colaboradores (2010), a grande maioria das pesquisas sobre o processamento de conteúdo audiovisual legendado, infelizmente, enfoca um subconjunto muito limitado de medidas. A ênfase desses trabalhos recai sobre a alocação de atenção (experimentos com rastreamento ocular) ou em medidas de desempenho relacionadas à leitura de legendas, como o reconhecimento textual. De maneira bastante objetiva, tarefas de reconhecimento textual consistem em averiguar se o participante, após a realização da tarefa, é capaz de identificar palavras ou legendas completas que foram exibidas; A capacidade de processar, reter e retomar informações visuais e o impacto da redundância nesses processos, amplamente estudados na Comunicação Visual (ZHOU, 2004), foram deixados 
praticamente de lado na Tradução Audiovisual. Assim, Perego aponta para a necessidade de desenvolver pesquisas que provenham uma análise mais abrangente de estratégias de processamento e sua eficiência, levando em conta movimentação ocular, desempenho do processamento de imagens e desempenho de processamento textual para avaliar adequadamente a eficiência do processamento de obras audiovisuais legendadas e a potencial troca de foco de atenção entre diferentes canais semióticos. A insatisfação de Perego e colaboradores (2010) fica clara em:

\begin{abstract}
"Infelizmente, devido às limitações metodológicas citadas, as pesquisas anteriores não fizeram avanços convincentes quanto a o processamento de uma obra audiovisual legendada ser feito de maneira relativamente pouco custosa, permitindo que haja um nível elevado de desempenho sem que ocorra uma descompensação da atenção dedicada ao texto e às imagens, ou seja, favorecendo a hipótese da eficiência cognitiva."3
\end{abstract}

Essas serão as motivações para os autores desenvolverem a pesquisa brevemente descrita no final deste capítulo.

Perego e colaboradores (2010), na esteira de pesquisas anteriores, como as conduzidas pela Escola Belga, investigaram a possível compensação de atenção (attention tradeoff) entre canais de informação prevista por modelos de seleção precoce de foco de atenção, ou seja, que a maior dedicação às legendas resultaria num decréscimo dos recursos cognitivos dedicados à imagem o que, por sua vez, afetaria negativamente o processamento de imagens. A autora ressalta, porém, que tais teorias contrastam com as propostas já mencionadas acima que preveem que tanto o processamento de imagens quanto de legendas é relativamente fácil e parcialmente automático e que a presença de imagens parece facilitar a compreensão de legendas ao fornecer um contexto, na maior parte das vezes, coerente e propício para a integração contínua de duas informações visuais (legendas e imagens) (RAYNER \& POLLATSEK, 1989 ZHOU, 2004).

\footnotetext{
3 'Unfortunately, due to the above mentioned methodological limitations, previous research did not make convincingly clear whether processing a subtitled program can be handled with relatively low effort, achieving good levels of performance, and without causing a tradeoff between image processing and text processing (i.e., our cognitive effectiveness hypothesis)."
} 
A não interferência e, em alguns casos, o papel facilitador de imagens no processamento de mensagens na comunicação midiática foi destacado por vários teóricos, dentre eles cito (GRIMES, 1991; LANG, 2001; ZHOU, 2004). Já a eficiência do processamento de textos legendados foi destacada por d'Ydewalle e Gielen (1992), onde os autores afirmam:

"Quando assistimos à televisão, a distribuição de atenção entre diferentes canais de informação é algo que não demanda esforço. Aparentemente, espectadores desenvolvem estratégias que permitem a eles processar esses canais sem problemas. A leitura das legendas possui papel central nesse processo (1992:425)." 4

Sem dúvida, as pesquisas de Perego (2008a/2008b e 2010) são as que dialogam mais intimamente com o presente trabalho, principalmente a última, em que a autora e seus colaboradores empregam um paradigma experimental a fim de verificar o impacto da segmentação interna de legendas.

Em Subtitles and line-breaks - Towards improved readability (2008a), Perego levanta hipóteses sobre o impacto da segmentação na leitura de legendas e possíveis consequências para a experiência de acompanhar uma obra audiovisual legendada. A autora destaca uma tendência a obedecer, na maioria das oportunidades, critérios estéticos/geométricos em detrimento dos linguísticos ao fazer uma análise qualitativa de um corpus variado de legendas de filmes sobre as quais comenta e formula hipóteses sobre instâncias arbitrárias de segmentação. A empreitada da pesquisadora tem caráter aplicado e busca prover soluções para desafios recorrentes de segmentação a partir de uma abordagem com foco no telespectador. Destaca-se nesse trabalho o fato de que até então poucos autores haviam se dedicado à investigação do impacto da segmentação de legendas, d'Ydewalle et al. (1985), Ivarsson and Carroll (1998), Karamitroglou (1998), Rundle (2000), Díaz Cintas (2003) e Perego (2005), somente. Em What would we read best? (2008b), a autora faz um levantamento de corpora de legendas em inglês e italiano as quais esmiúça sintaticamente por tipos de sintagma: nominais, verbais,

\footnotetext{
4 "When people watch television, the distribution of attention between different channels of information turns out to be an effortless process. Viewers seem to have developed a strategy that allows them to process these channels without problems and in which reading the subtitles occupies a major place"
} 
adjetivais e preposicionais e as relações de coordenação e subordinação entre orações, e constata que, na prática, as orientações definidas para segmentação, visando a facilitação do processamento, raramente são seguidas. Em suas conclusões, a autora cita a possibilidade de embasar suas hipóteses com dados obtidos através de rastreamento ocular num futuro próximo, o que se confirma em Perego e colaboradores (2010).

Em 2010, os autores conduzem um experimento de rastreamento ocular com três objetivos: i) testar a hipótese da efetividade cognitiva do processamento de legendas como vista em d'Ydewalle e colaboradores (1991) analisando a relação entre reconhecimento de palavras e cenas; ii) testar a influência da segmentação linguística no processamento cognitivo e na capacidade de reconhecimento e iii) prover novas evidências empíricas sobre o processamento de legendas com base em dados decorrentes do rastreamento ocular de sujeitos assistindo obras audiovisuais. Desta forma, aliando medidas offline (análise de reconhecimento de palavras e cenas) e online (rastreamento ocular), Perego e colaboradores acreditam prover uma fundamentação mais completa para a compreensão da maneira como obras audiovisuais legendadas são processadas do que pesquisas anteriores, que se apoiavam em apenas um dos dois tipos de medidas supracitadas.

Os autores buscam testar 3 hipóteses:

i) A primeira hipótese dos autores também é motivadora do trabalho, haja vista que ela já era alvo de discussão na literatura. A hipótese de trabalho de Perego e colaboradores é a de que, durante o processamento de obras audiovisuais legendadas, ocorre uma descompensação (trade-off) entre processamento de texto e imagem. Tal hipótese é defendida por autores como Grillo \& Kawin (1981) que postulam que a atenção deve ser alocada flexivelmente entre informações paralelas durante a tarefa, de forma que, quando o foco do telespectador recai sobre as legendas, o processamento das imagens seria prejudicado e vice-versa. Essa hipótese é compatível com teorias sobre a alocação de atenção que postulam a seleção precoce de canais de informação (BROADBENT, 1958; TREISMAN, 1968) e com a literatura sobre processamento de conteúdo televisivo, que prevê uma sobrecarga das capacidades de processamento do telespectador, principalmente na presença de canais semióticos não isomórficos. Em suma, a 
hipótese de trabalho dos autores é que há uma relação negativa entre medidas de reconhecimento de texto e de imagem. Essa hipótese diverge do que é defendido por outra gama de pesquisadores, como LaBerge \& Samuels (1974) e Lang (2000 e 2001), para os quais o ato de assistir a um programa legendado não configura um desafio, pois tanto o processamento textual quanto o visual são atividades cognitivas altamente eficientes e parcialmente automatizadas.

ii) A segunda hipótese testada pelos pesquisadores diz respeito especificamente à segmentação textual e seu impacto no processamento de legendas. Os autores defendem que legendas mal segmentadas prejudicam significativamente o processamento informacional, reduzindo a velocidade de leitura e causando uma diminuição significante do reconhecimento textual (PEREGO 2008A, 2008B) e essa hipótese diverge do que é afirmado por outros autores, que defendem que a leitura de legendas é um processo parcialmente automatizado que requer pouco esforço. (D'YDEWALLE \& DE BRUYCKER, 2007; D'YDEWALLE \& GIELEN, 1992).

Os autores apresentam algumas previsões em relação ao comportamento ocular durante o processamento de obras audiovisuais legendadas, mais especificamente à divisão de atenção entre legendas e imagens. No caso da hipótese defendida no trabalho (de que ocorre uma descompensação entre processamento de texto e imagem durante o processamento de obras audiovisuais legendadas) se sustentar, a previsão é que haja um maior número de fixações nas legendas e fixações mais longas nas imagens. Já para a hipótese defendida por outras correntes (de que obras audiovisuais legendadas não apresentam desafios ao expectador), a previsão é de haja um maior número de fixações em outra(s) região(iões) da tela e fixações mais longas em outra(s) região(ões) da tela.

A amostra de Perego e colaboradores foi constituída por 41 alunos de graduação e pós-graduação da Universidade de Trieste e da Universidade de Pavia. Para evitar possíveis efeitos de bilinguismo, foi utilizado um trecho de um filme húngaro, de cujo idioma nenhum dos participantes tinha algum conhecimento. Os sujeitos foram divididos em dois grupos $(\mathrm{n} 1=20, \mathrm{n} 2=21)$ a fim de contrabalancear a apresentação entre sujeitos de legendas bem e mal segmentadas. A ordem de apresentação das duas condições foi contrabalanceada entre sujeitos, ou seja, num 
mesmo vídeo havia instâncias de boa e má segmentação para cada sujeito em ordem aleatorizada.

Os participantes assistiram a um trecho de 15min do drama húngaro Szerelmesfilm (SZABÓ, 1970) com legendas em italiano. Por limitações de tempo, de acordo com os autores, apenas 16 dos 41 sujeitos tiveram dados de rastreamento ocular registrados. Os sujeitos assistiram ao trecho de vídeo individualmente com fones de ouvido numa sala com ruídos externos controlados. Em seguida, foi pedido aos participantes que preenchessem 3 questionários na ordem: i) leitura de legenda; ii) apreensão geral (gist comprehension) e iii) reconhecimento de palavra. Logo depois, os participantes foram submetidos ao teste de reconhecimento de cena.

As variáveis dependentes foram medidas de desempenho em tarefas de reconhecimento de palavras e de cenas. A primeira foi obtida a partir de um questionário de múltipla escolha, enquanto a segunda, através de um teste feito em um computador, em que os participantes deveriam reconhecer fotogramas específicos como pertencentes ou não aos trechos que acabaram de assistir . Para os participantes que tiveram seus dados de rastreamento ocular registrados, a variável dependente foi o número de fixações no terço inferior da tela (considerada fixações nas legendas) e nos terços médio e superior (consideradas fixações na imagem). A duração mínima de uma fixação foi definida em 100ms num raio de 30 pixels.

No primeiro questionário, referente à leitura das legendas, os participantes da pesquisa relataram utilizar as legendas sempre ou frequentemente $(\mathrm{M}=6.6, \mathrm{SD}$ $=1.02$ ) e afirmaram que a presença de legendas facilitou ou facilitou muito a compreensão do filme $(\mathrm{M}=6.6, \mathrm{SD}=0.7)$. $\mathrm{O}$ relato dos participantes corroborou as respostas sobre o aspecto visual das legendas: $95 \%$ da amostra lembrou-se do alinhamento das legendas e $68 \%$ lembrou-se da cor. Associados aos dados obtidos via rastreamento ocular, os valores acima demonstram que os participantes de fato leram as legendas e as utilizaram para compreender o filme. Além disso, os sujeitos relataram que a leitura de legendas foi muito fácil ou fácil $(\mathrm{M}=6.00, \mathrm{SD}=0,93)$; consideraram muito fácil acompanhar o filme $(\mathrm{M}=5.12, \mathrm{SD}=1.03)$ e julgaram a própria compreensão muito boa $(\mathrm{M}=4.95, \mathrm{SD}=1.07)$. 
Já no segundo questionário, que buscava averiguar a apreensão geral (gist comprehension), os participantes demonstraram boa compreensão geral do filme, tanto da primeira parte quanto da segunda. A proporção de respostas corretas foi de .75 para a primeira parte e .91 para a segunda. Um teste $t$ salientou que a compreensão da segunda parte foi significativamente superior à da primeira. $(\mathrm{t}(40)$ $=-5.87, \mathrm{p}<.0001)$. O melhor desempenho na segunda parte pode ser explicado pelo fato de os participantes já estarem acostumados com a tarefa ou ainda pelo maior controle executivo de alguns dos participantes.

Além das medidas apontadas acima, Perego e colaboradores (2010) utilizaram medidas de desempenho - também via questionário -, como o reconhecimento de palavras. Os participantes demonstraram maior dificuldade no teste de reconhecimento de palavras do que nos outros, todavia tiveram bom desempenho na tarefa. Uma análise mista da variância (ANOVA), levando em conta os fatores primeira e segunda parte do vídeo e boa e má segmentação, deu origem a um design $2 \times 2$. A qualidade da segmentação não teve efeito em nenhuma das partes do vídeo, porém o reconhecimento de palavras foi significativamente mais difícil na primeira parte.

Já no teste de reconhecimento de cenas, em que os sujeitos deveriam identificar se determinados frames foram exibidos ao longo do filme, a taxa de acerto foi altíssima em ambas partes do filme (.90 e .87). A qualidade da segmentação das legendas, assim como no teste de reconhecimento de palavras, não afetou significativamente o desempenho dos participantes. Ou seja, os dados parecem indicar que não há uma correlação entre qualidade da segmentação textual e a capacidade de apreender visualmente um filme.

No que tange o rastreamento ocular, o número de fixações na porção legendada da tela foi três vezes maior do que no resto da tela $(t(15)=-8.53, p<$ .0001), todavia a duração média das fixações na área legendada foi significativamente menor do que a duração média das fixações nas outras regiões da tela. Os participantes gastaram $67 \%$ do tempo de fixação na porção legendada do vídeo. Não houve diferença significativa no número de fixações ente as condições boa X má segmentação. Tais condições também não impactaram no número de fixações nos 2/3 superiores da tela (área não legendada). 
Os resultados de Perego e colaboradores (2010) são compatíveis com a hipótese de que obras audiovisuais legendadas não apresentam desafios ao espectador, defendidas por d'Ydewalle \& De Bruycker (2007) e d'Ydewalle \& Gielen (1992), pois nenhum dos testes indicou alguma descompensação entre processamento de texto e imagem. Por sua vez, a hipótese de que ocorre uma descompensação entre processamento de texto e imagem durante o processamento de obras audiovisuais legendadas manteve-se em iii (reconhecimento de palavras), haja vista que um maior número de fixações foi concentrada na porção legendada da tela, ao passo que fixações mais longas ficaram concentradas nos $2 / 3$ superiores da tela.

Em suma, os dados parecem corroborar a hipótese de que o processamento de obras legendadas é de fato extremamente otimizado e que telespectadores provavelmente utilizam estratégias para alocação de atenção que permitem a boa compreensão de informação veiculada tanto visual quanto acusticamente.

Já Diniz (2012) foca seu trabalho na análise de categorias de segmentação entre linhas nas legendas (em português brasileiro, criadas para um filme brasileiro) de duas modalidades: legendas para ouvintes e legendas para surdos e ensurdecidos. Por conta da necessidade presente nas legendas para surdos e ensurdecidos de transmitir informações adicionais na tela, a autora investiga os critérios não linguísticos motivadores da quebra de linha de legendas e examina os desvios linguísticos na legendagem para surdos e ensurdecidos, comparando-os aos que ocorrem em legendas para ouvintes. Diniz utilizou como procedimentos metodológicos a análise de dados quantitativos, a anotação manual e o rastreamento de categorias de segmentação. A autora relata que os resultados em geral indicam que as duas modalidades não apresentam muita diferença entre si em termos textuais e técnicos, havendo poucas escolhas diferentes de quebra de linha entre as modalidades. Ela relata ainda que há uma preferência do legendista pela legendagem verbatim (prática em que se transcreve a maior parte do discurso) e que o fator não linguístico mais levado em consideração na quebra de linha foi a preferência por criar, quando havia duas legendas, uma legenda superior mais curta que a inferior. 
Araújo \& Assis (2014), por sua vez, analisam os problemas de segmentação linguística nas legendas para surdos e ensurdecidos de um capítulo de novela. As autoras realizam uma análise descritiva baseada em corpus como procedimento metodológico e apresentam resultados que revelaram problemas de segmentação linguística em 25,5\% das legendas (os mais frequentes foram relativos à ordem dos sintagmas verbais e nominais em legendas de 3 linhas com velocidade de leitura alta).

Representando mais um estudo na área de legendagem para surdos e ensurdecidos, Chaves (2012) também investigou problemas de segmentação. A autora parte da premissa de que a segmentação é um fator crucial no processamento de legendas, podendo impacta-lo de forma positiva ou negativa, e, realizando um estudo descritivo baseado em corpus, relatou os problemas de segmentação nessa modalidade de legenda em filmes. Os resultados apresentados por Chaves sugerem que os problemas de segmentação concentram-se majoritariamente no nível do sintagma, principalmente o verbal, e a autora observou que tais problemas normalmente acontecem em legendas de duas linhas e com velocidade alta.

Por fim, Pagano, Alves e Araújo (2011) é um trabalho precursor na investigação experimental do processo tradutório em legendagem por um viés da expertise. Os autores realizaram uma experimente-piloto no qual buscaram examinar o ritmo cognitivo dos sujeitos; comparar as legendas produzidas por tradutores experientes e aprendizes de tradução em termos de velocidade de leitura, segmentação e resumo; e analisar as escolhas linguísticas dos diferentes sujeitos e sua adequação ao linguajar do produto audiovisual com base na linguística sistêmico-funcional. O caráter preliminar desse experimento, que contou com seis participantes, permitiu apenas conclusões preliminares, todavia, apontou para diferenças entre os grupos que justificam novas pesquisas com maior grau de refinamento.

Com a presente dissertação, tenho a intenção de fazer contribuições, certamente em níveis dessemelhantes, para as seguintes áreas: Nos Estudos da Tradução, colaborar para o entendimento do processo de tradução para legendagem, das competências necessárias a essa prática e para o refinamento do conhecimento existente sobre questões de segmentação textual. Na Psicolinguística, espero 
colaborar para a compreensão do fenômeno das sentenças garden-path e para a criatividade dos paradigmas experimentais adotados na área.

\section{3}

\section{Processos de leitura}

A leitura é uma atividade complexa, que envolve diversos subprocessos cognitivos relacionados tanto ao conhecimento linguístico quanto ao conhecimento de mundo. Há na literatura diversos modelos e posicionamentos em relação aos processos de leitura; nesta dissertação, eu me apoio no modelo de Perfetti (1999) para uma caracterização geral dos processos envolvidos na leitura.

De acordo com Perfetti (1999), para que se compreenda o processo cognitivo da leitura, é necessário referir-se a três fases gerais de processamento: os processos visuais, os processos de conversão do input visual em representações linguísticas e os processos que operam na representação codificada. Os processos visuais, apesar de muito importantes, são apenas o input inicial ao leitor. São processos exclusivos da leitura aqueles que desempenham a decodificação do input visual em formas linguísticas - essa decodificação torna uma gama de significados e traços gramaticais disponível para o processo de compreensão.

O esquema apresentado na página seguinte — adaptado do apresentado em Perfetti (1999) - representa as fontes de informação que se espera que um leitor utilize para compreender o texto escrito. Esse esquema representa as duas grandes classes de instâncias de processamento: a identificação de palavras e o uso de mecanismos de processamento linguístico que agrega essas palavras em estruturas sintáticas que permitam a recuperação do conteúdo da mensagem expressa. De acordo com Perfetti et al (2005), esses processos fornecem significados das palavras apropriados ao contexto, organizam sequências de palavras em constituintes e permitem a integração das informações da sentença a representações mais complexas do texto. Essas representações não são resultado de processos exclusivamente linguísticos, sendo também afetadas de forma crucial por outras fontes de conhecimento. 


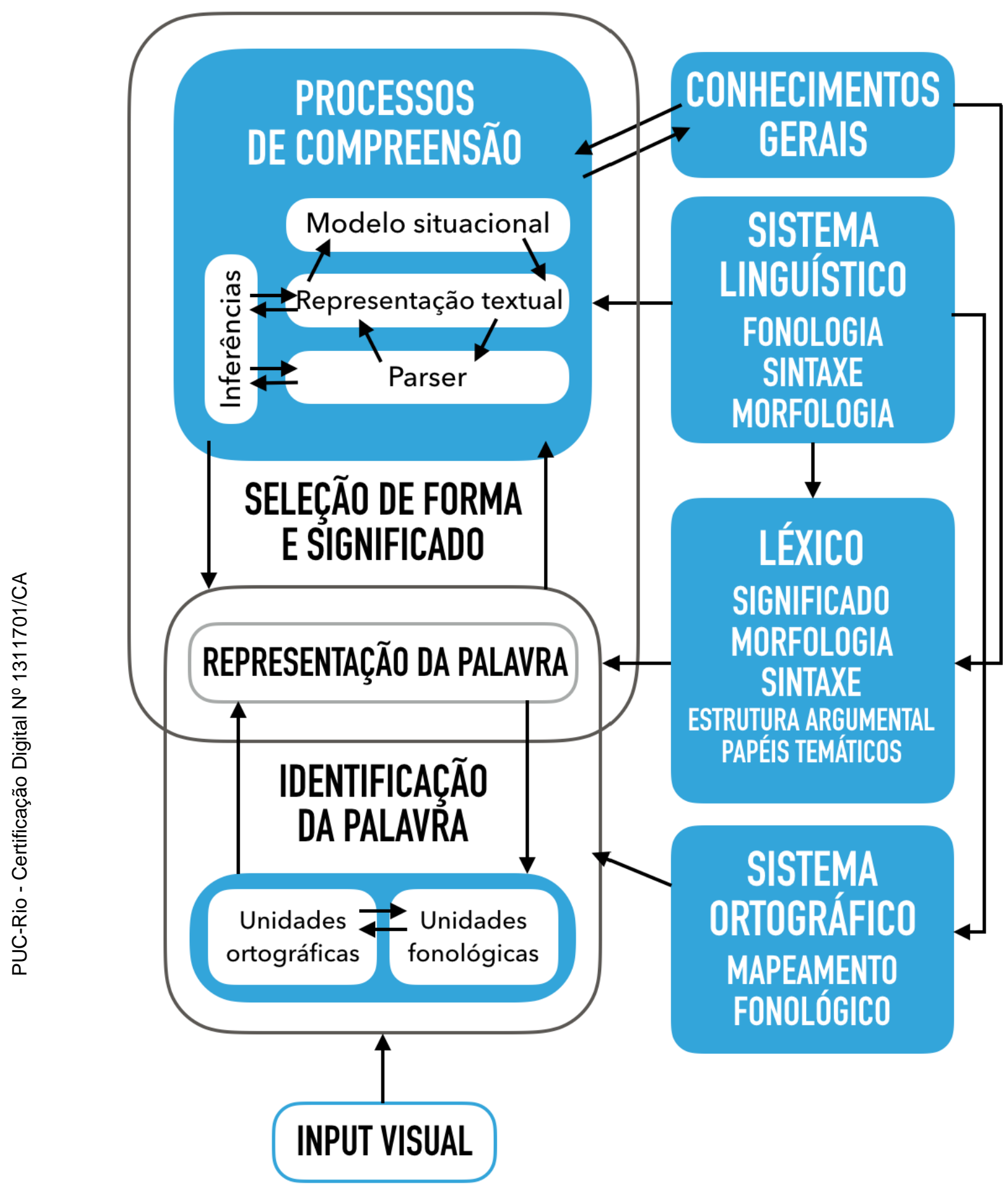

Figura 1: Esquema dos componentes gerais do processo de leitura, adaptado do esquema de Perfetti $(1999, \text { p.169) })^{5}$

\footnotetext{
5 As setas indicam fluxo informacional. Perfetti (1999) observa que é uma questão empírica se setas bidirecionais são necessárias em todos os casos indicados no esquema.
} 
Ao ser exposto ao input visual, o leitor começa o processo de identificação da palavra, mapeando unidades ortográficas e fonológicas para identificar a representação da palavra. Em seguida, após a seleção das representações de natureza semântica e formal mais apropriadas, começam os processos de compreensão propriamente ditos e que levarão às representações do conteúdo global do texto. Tais processos são a construção do modelo situacional, a construção da representação textual, o parsing sintático e a realização de inferências.

É importante notar que, vários tipos de conhecimentos (como o do sistema ortográfico, do sistema linguístico, do léxico e conhecimentos gerais) são mobilizados no processamento da leitura, como se pode ver pelo esquema.

Neste trabalho, tenho como foco os processos direcionados mais especificamente à atribuição de uma estrutura sintática às sentenças, o que em Psicolinguística tem sido investigado sob o nome de parsing.

\section{1}

\section{Parsing sintático}

De acordo com van Gompel e Pickering (2006), uma das etapas mais essenciais do entendimento de sentenças envolve a construção das estruturas sintáticas. Sem isso, seria muito difícil compreender que frases com os mesmos elementos em ordens diferentes têm significados diferentes e que determinados tipos de frase podem ter mais de uma interpretação possível, devido a ambiguidades estruturais. O processo de construir estruturas sintáticas durante a compreensão da linguagem é normalmente chamado de processamento sintático ou de parsing, termo que vem do Latim pars (orationis) e significa "partes do discurso".

O parsing é um processo incremental, ou seja, as palavras vão sendo incorporadas à estrutura sintática à medida que vão surgindo — não se espera que todas as palavras sejam lidas/ouvidas para que se possa construir a estrutura sintática; essa construção ocorre em tempo real. Há diversos estudos apresentando 
evidências que corroboram essa visão, como Clifton et al (2003), Ferreira \& Clifton (1986), Rayner et al (1983), Trueswell et al (1994), dentre outros.

Neste trabalho, assumimos uma abordagem modular de parsing, segundo a qual as decisões iniciais do parser envolvem apenas informação de natureza estrutural, não sendo sujeitas a interferência de outras fontes. $\mathrm{Na}$ literatura, é comum a utilização de experimentos com sentenças ambíguas (temporárias ou não) para investigar a modularidade no processamento de sentenças. Esse tipo de estudo permite a investigação de como diferentes fontes de informação são empregadas durante o processamento de sentenças sintaticamente ambíguas, para as quais são permitidas diversas interpretações. Há uma ampla literatura a esse respeito, mas

foge ao escopo deste trabalho apresentar essa discussão. É mandatório, no entanto, ressaltar a discussão que envolve a pesquisa sobre orações ambíguas no que tange as afiliações teóricas possíveis. Embora a abordagem adotada na presente pesquisa esteja alinhada com propostas modulares de parsing, não se pode ignorar que propostas não modulares de parsing, que consideram a atuação de processos preditivos no processamento de sentenças, oferecem um contraponto interessante para a pesquisa na área. Nos experimentos, como será visto no capítulo 5, busco avaliar se os revisores de legendas são sensíveis à presença de estruturas ambíguas nas legendas e se buscam estratégias para evitar segmentações que levem a mais de uma interpretação da sentença. Sendo assim, optei por apresentar nesta seção a teoria tida como mais influente na investigação de resolução de ambiguidades durante a leitura - a Teoria do Garden Path.

\section{2}

\section{Teoria do Garden Path}

A Teoria do Garden Path (Frazier, 1979; Frazier \& Fodor, 1978), ou Teoria do Labirinto é um modelo de processamento modular e serial - o labirinto foi escolhido como metáfora devido a sua estrutura similar a desse tipo de frase, que apresenta bifurcações a serem escolhidas, sendo algumas delas caminhos que permitem que se continue a trafegar e outras trilhas sem saída, que não levam a lugar algum e tornam necessário que se volte atrás para escolher outro caminho, exatamente como ocorre em sentenças Garden Path. 
De acordo com a teoria, a compreensão de uma frase se dá em dois estágios, o Preliminary Phrase Packager, no qual os itens lexicais são estruturados em sintagmas, e o Sentence Structure Supervisor, na qual os sintagmas são reestruturados em um marcador frasal completo (Maia, 2009). Na primeira fase do processamento ocorre o parsing guiado exclusivamente pelas informações sintáticas do input. Como já foi dito, a ação do parser é imediata e incrementacional, ou seja, cada novo item que surge é incorporado imediatamente à estrutura sintática que está em construção. De acordo com Frazier (1979), nessa primeira fase, o processador adota a estrutura mais simples, apondo os itens usando o menor número de nós sintáticos (seguindo o princípio chamado Minimal Attachment) ou, se as estruturas possíveis forem igualmente complexas, toma-se por base a aposição local dos itens, apondo os itens que vão surgindo ao nó não terminal mais baixo possível dominando o último item analisado (seguindo o princípio de Late Closure). O efeito garden-path ocorre quando essas interpretações, feitas de forma automática e precoce pelo parser, revelam-se inadequadas - ocorre então uma suspensão do processamento, que necessita da reanálise do input para continuar (segunda fase).

A critério de exemplificação, cito aqui o exemplo estruturalmente ambíguio utilizado por Ribeiro (2012), "Maria viu o homem com os binóculos". Nessa frase, de acordo com a Teoria do Garden Path, o parser computaria, primeiramente, somente a ligação sintática do sintagma preposicional ("com os binóculos") ao sintagma verbal ("viu o homem"), por ser a computação com menor número de nós sintáticos, seguindo o princípio de Minimal Attachment. Nessa leitura, os binóculos são o instrumento utilizado por Maria para ver o homem. Apenas num segundo momento, já em outro estágio de processamento, são acessadas informações contextuais para avaliar a primeira decisão, fazendo, caso seja necessário, com que o processador reanalise o input para chegar à interpretação mais adequada da frase. No caso do exemplo, essa outra interpretação poderia ser que Maria viu um homem e esse homem carregava binóculos consigo.

Já no clássico exemplo “ $O$ bandido atirou na empregada da atriz que estava na varanda", a ligação da oração relativa aos antecedentes gramaticalmente legítimos "empregada" ou "atriz" resulta em estruturas de complexidades indistintas, de forma que não ocorre o Minimal Attachment. Dessa forma, segue-se 
o princípio Late Closure, ou pelo menos essa é a previsão da Teoria do Garden Path. Porém, é interessante apontar que, apesar dessa previsão se sustentar em diversas línguas, dados do espanhol (Cuetos \& Mitchell, 1988), português (Ribeiro, 2004), francês (Zagar et al., 1997), holandês (Brysbaert \& Mitchell, 1996) e croata (Lovric, 2003) indicam que os falantes dessas línguas não realizam Late Closure, mas sim Early Closure, princípio que implica que o sintagma seja fechado o mais rapidamente possível, por conta de restrições da memória de trabalho. Para explicar o fenômeno, foram propostas algumas hipóteses, como a Tuning Hypothesis (Hipótese da Sintonia), de Mitchell e Cuetos (1991), que propõe que o leitor analisaria inicialmente a sentença ambígua com base nas experiências que teve anteriormente com sentenças não ambíguas, e o processo de Construal, de Frazier e Clifton Jr. (1996), aplicável, por exemplo, a orações relativas, e que permitiria o acesso a diversos tipos de informações, como de cunho semântico e pragmático durante o processamento desse tipo de estrutura. O processo de Construal faz parte do refinamento proposto por Frazier e Clifton Jr. para a Teoria do Garden Path, de acordo com o qual ocorreria a distinção entre relações primárias (aquelas que se estabelecem entre sujeito e predicado) e não primárias durante o processamento sintático - dessa forma, as relações primárias se baseariam somente na ligação sintática dos constituintes e seguiriam obrigatoriamente os princípios do parsing, enquanto as não primárias, devido à interferência de informações de outras naturezas, não necessariamente seguiriam tais princípios, sendo possível assim ocorrer Early Closure nas línguas citadas acima sem que a universalidade da teoria seja comprometida.

Ao longo dos anos, outros princípios foram incorporados à Teoria do Garden Path: o princípio do Active Filler, que consiste em "identificar um elemento ativo na periferia esquerda e associá-lo à primeira lacuna disponível” (Maia, 2009), a Most Recent Filler Strategy, em que se "associa uma lacuna ao antecedente mais recente" (Ibidem, 2009), e o Minimal Chain Principle, que implica "postular rapidamente análises com menos cadeias e cadeias com menos elos" (Ibidem, 2009).

Porém, é importante ressaltar, conforme lembra Ribeiro (2012), que, após a reanálise de uma estrutura garden path, nem sempre a interpretação final de uma frase reflete o valor-de-verdade do input. Christianson et al. (2001) apresentam 
evidências de que, durante a reanálise de frases garden-path, quando o parsing segue Late Closure, muitas vezes a reanálise não é concluída, de forma que a interpretação final acaba sendo imprecisa, ou "good-enough", que é explicada em mais detalhes na próxima seção.

\section{3}

\section{O processamento Good-Enough}

Christianson et al. (2001) apontam que, na literatura relativa a reanálises de garden path, costuma-se pressupor que ou i) o leitor/ouvinte faz uma reinterpretação completa da leitura imprecisa inicial, de forma a se chegar a uma interpretação final cuja estrutura sintática é totalmente consistente com o input, ou ii) o processamento falha. Os autores, porém, discordam que haja somente essas duas opções, e apresentam resultados de três experimentos que indicam que a reanálise de sentenças garden path pode, por vezes, não ser finalizada ou completada. Dessa forma, os leitores/ouvintes podem terminar o processo com uma interpretação para a sentença em que parte da análise equivocada inicial ainda persista (mais especificamente, a interpretação inicial persistiria na memória de trabalho e, mesmo após a reanálise, interferiria na interpretação final). Os autores sugerem, então, que o objetivo do processamento não seja criar uma estrutura perfeita, mas apenas criar uma representação que seja "good enough" (boa o suficiente) para satisfazer a necessidade do leitor/ouvinte de ter uma interpretação minimamente apropriada.

Ferreira et al., (2002) também apresentam evidências de que o sistema de compreensão de linguagem nem sempre é capaz de produzir representações semânticas corretas, detalhadas e completas do input e que a interpretação de frases pode, por vezes, não resultar necessariamente da soma dos significados de suas partes, mesmo após a reanálise.

Em português do Brasil, Ribeiro (2008; 2009; 2010; 2010a), conduziu estudos que corroboram as descobertas de Ferreira et al. (2002) e dos achados de Christianson et al. (2001). Nesses experimentos, Ribeiro, fazedo uso de diferentes 
técnicas experimentais (estudos de questionário, leitura auto-monitorada, rastreamento ocular) observou que, em sentenças como "Enquanto o aluno lia as anotações caíram da mesa", os participantes, ao serem perguntados se "O aluno lia as anotações?", um percentual alto respondia afirmativamente à pergunta, o que evidencia a persistência da análise inicial do SN ambíguo (as anotações) na memória de trabalho dos participantes.

Fatores como plausibilidade e extensão da região ambígua foram identificados como fatores que podem favorecer ocorrência de reanálise incompleta do input e representações good-enough no processamento de sentenças. Em relação à plausibilidade, Ribeiro (2009) identificou que, no contraste entre a sentença acima citada, "Enquanto o aluno lia as anotações caíram da mesa" (plausível) e a sentença "Enquanto o aluno lia as anotações queimaram na lareira" (implausível), a primeira determinou uma maior persistência a análise do SN "as anotações" como objeto direto de "lia". No que tange à extensão da região ambígua, Ribeiro (2010a) verificou que a extensão da região ambígua induz a persistência da análise inicial do SN ambíguo. Assim, na comparação entre "Enquanto o homem caçava os cervos que eram fortes e ágeis correram para a floresta" (região estendida) e "Enquanto o homem caçava os cervos correram para a floresta" (região curta), houve um percentual mais alto de respostas afirmativas para a pergunta " $\mathrm{O}$ homem caçava os cervos?" para a região estendida $(58 \%)$ do que para a curta $(39 \%){ }^{6}$

Na pesquisa conduzida durante esta dissertação, principalmente com base no segundo experimento, busco acrescentar mais dados à literatura da área, utilizando um paradigma (possivelmente) inédito, a fim de colaborar com a discussão relativa ao papel da segmentação sentencial no processamento de sentenças ambíguas no contexto da legendagem. Interessa-nos verificar o quanto o profissional de legendagem, em especial no processo de revisão (exp. 2), é sensível à presença de sentenças que podem gerar um efeito garden-path e utiliza estratégias eficientes para evitar as ambiguidades estruturais. Entendo que, dada a complexidade da tarefa da leitura de legendas determinada por vários fatores, entre os quais a sobreposição de diferentes canais de significado, o revisor deve buscar

\footnotetext{
${ }^{6}$ Ribeiro observa que esse resultado foi obtido quando a extensão da região ambígua envolvia orações relativas, mas o mesmo não ocorreu com adjetivação pós-nominal.
} 
otimizar o processamento das legendas. A segmentação textual feita de maneira equivocada pode prejudicar e até impossibilitar a compreensão do público-alvo, de forma que o conhecimento de sentenças que induzem garden path e de seu impacto para pessoas que dependem das legendas para usufruir de um determinado conteúdo audiovisual torna-se imprescindível ao profisssonal de tradução/revisão para legendagem. No experimento 2 desta dissertação, tradutores experientes e aprendizes são testados a fim de compreendermos melhor como eles lidam com esse tipo de sentença.

Em relação especificamente ao processamento "good enough", embora nossos experimentos não visem a investigar diretamente essa questão, o tópico é relevante para nossa pesquisa, pois, como destacado acima, fatores como extensão da região ambígua podem favorecer reanálise incompleta do input, o que pode comprometer a compreensão da sentença. Ademais, é possível que as demandas impostas pela leitura de legendas em contexto multimodal - a qual envolve diferentes canais semióticos (texto da legenda, imagens dinâmicas e estímulos auditivos) - venham a favorecer uma compreensão superficial, de natureza heurística dos estímulos linguísticos (Ferreira \& Patson, 2007). Este é um aspecto, pois, que precisa ser considerado quando se considera o papel da segmentação na legendagem. 
4

\title{
Expertise e experiência em uma abordagem cognitiva da tradução
}

As palavras "expert" e "expertise", em grande medida, estão incorporadas ao léxico de muitos brasileiros, estando inclusive dicionarizadas, como podemos ver nas definições do Dicionário Houaiss abaixo:

\author{
"m substantivo de dois gêneros \\ Indivíduo com habilidade ou conhecimentos especiais que o fazem \\ dominar determinado saber ou fazer humano \\ - substantivo feminino \\ 1 competência ou qualidade de especialista \\ 2 perícia, avaliação ou comprovação realizada por um especialista \\ em determinado assunto \\ Exs.: e. de uma obra de arte e. Criminológica"
}

Embora as acepções acima estejam corretas, pode-se afirmar com certa tranquilidade que ambos os termos são mais comumente empregados para descrever profissionais, especialistas ou peritos cuja função é fornecer orientar e/ou supervisionar uma determinada tarefa com base em um conhecimento profundo, inobstante a maneira de sua aquisição, distanciando-se do que se convencionou chamar Estudos em Expertise.

Os Estudos em Expertise, embora sem a coesão que hoje vemos nesse campo - algo que só veio a acontecer na década de 1970, tiveram seu início com o uso de protocolos verbais na Psicologia Cognitiva, cujas primeiras aplicações foram feitas com aprendizes que narravam em voz alta suas decisões para tarefas cotidianas enquanto as realizavam (DUNCKER, 1945) ou enxadristas especialistas que explicitavam seu raciocínio enquanto escolhiam movimentos no tabuleiro de xadrez (DE GROOT, 1946). O conceito de expertise passou a ser empregado na área de Tradução no âmbito dos trabalhos que se voltam para a investigação da competência tradutória que os participantes têm para realizar os procedimentos necessários ao desempenho adequado de sua função. Nesses trabalhos, considerase que a experiência profissional é um dos fatores que pode contribuir para alcançar um desempenho experto, e é a esse aspecto da expertise que esta pesquisa se dedica. 
Shreve (2006) propõe que tomemos como pressuposto que aspectos cognitivos subjacentes à expertise são análogos entre diferentes domínios de conhecimento e apresenta uma proposta de interface entre os estudos sobre expertise e desempenho experto e as abordagens empírico-experimentais nos estudos da tradução. $\mathrm{O}$ autor defende que há uma interseção entre o conceito de competência tradutória, como visto acima, e expertise em tradução, com base em pesquisas na linha dos trabalhos em expertise e desempenho experto em diferentes domínios. Dado o pressuposto acima, o autor destaca que o maior interesse nessa interface é a compreensão sobre as condições e formas sob as quais a competência tradutória se desenvolve para embasar a expertise.

Ao aproximar a discussão sobre expertise e o campo da tradução, Shreve (2006) sugere que, do ponto de vista dos estudos sobre expertise e desempenho experto, a competência tradutória (doravante CT) pode ser definida como "a habilidade desenvolvida pelo tradutor para empregar múltiplos recursos cognitivos relevantes para a realização de uma tarefa de tradução". Para o autor, a CT pode ser vista, ainda, como o conjunto de conhecimentos declarativos e procedimentais em uma variedade de domínios cognitivos, acumulados por meio de treinamento e experiência e, portanto, armazenados organizadamente na memória de longo prazo do tradutor. Ainda de acordo com Shreve (2006), com o passar do tempo, esses múltiplos recursos cognitivos importantes para a tradução podem evoluir e configurar um "desempenho consistente de alto nível". Dessa forma, o autor afiliase aos estudos sobre conhecimento experto e passa a defender a noção de que no campo da tradução tal desempenho consistente de alto nível é o que, de fato, configura a expertise em tradução. Destarte, o autor sugere que as pesquisas sobre expertise sejam dedicadas à investigação da CT e de como ela vem a se tornar um tipo específico de conhecimento experto.

Alvez e Hurtado Albir (2010) demonstram que a discussão sobre a noção de competência tradutória deve ter como enfoque, acima de tudo, aspectos cognitivos subjacentes à capacidade tradutória que os participantes têm para realizar os procedimentos necessários ao desenvolvimento adequado da tradução. Uma das primeiras definições de competência tradutória é apresentada por Bell (1991), que a conceitua como um tipo de conhecimento experto guiado primordialmente por um componente estratégico. Diversos autores partiram das 
premissas de Bell para desenvolver seus modelos de CT; como Kiraly (1995), Pacte (2003), Gonçalves (2003) e Alves e Gonçalves (2007), para mencionar alguns.

Os autores supracitados concordam que a CT é formada por várias subcompetências, como o conhecimento linguístico bilíngue, conhecimento enciclopédico, conhecimento instrumental, conhecimento teórico sobre tradução e conhecimento estratégico. Esses autores sugerem, ainda, que tais subcompetências sejam investigadas experimentalmente a fim de mensurar em que medida elas são constitutivas da CT.

A aquisição de múltiplos recursos cognitivos (ou subcompetências em tradução) implica que a expertise em tradução pode se desenvolver de diferentes maneiras, a depender da experiência e do modo de aquisição de habilidades de um determinado domínio. Daí a relevância de pesquisas que visam a mapear o processo tradutório por meio de paradigmas experimentais, numa aproximação com a Psicolinguística. A pesquisa de caráter qualitativo com vistas à modelagem empírico-experimental da expertise em tradução parte de um sujeito experto prototípico, cuja definição é feita a partir de parâmetros quantitativos, com o objetivo de estabelecer bases para evidenciar o desempenho consistente de alto nível.

Os dados processuais, aqueles que registram o esforço de processamento, são obtidos através do cruzamento de informações de key logging (rastreamento de teclado e mouse), rastreamento ocular e relatos retrospectivos. A utlização de dados obtidos a partir dessas diferentes técnicas em conjunto na investigação do processo tradutório configura o que se tem chamado de paradigma de triangulação de dados. Essas técnicas, como demonstrado por Alves (2015), proveem as bases para pesquisa do processo tradutório. Nesta pesquisa, no entanto, não se faz o uso tradicional dos protocolos verbais, pois não há uma análise sistemática os protocolos à luz de uma teoria específica. Os protocolos, no entanto, são lidos por completo à procura de informações que confirmem ou contraponham o comportamento dos participantes a fim de embasá-lo.

Enquanto a técnica de key logging fornece dados precisos sobre a digitação e os cliques do participante, como pausas, intervalos, lapsos, correções, 
segmentação textual e reescritura, a técnica de rastreamento ocular fornece dados precisos sobre a movimentação dos olhos durante uma determinada tarefa. As pesquisas que se baseiam nesse recurso partem do pressuposto de que movimentos oculares refletem o estado cognitivo do indivíduo num determinado momento e, consecutivamente, são capazes de prover um insight sobre como e quando certas informações são processadas. É plausível dizer que, ao direcionar o olhar para um ponto específico, direcionamos também nossa atenção visual com a intenção de processar informações nele contidas ou a ele relacionadas.

$\mathrm{Na}$ pesquisa do processo tradutório, pode-se averiguar, então, a atenção dispensada a uma determinada palavra ou expressão, por exemplo, e até mesmo processos de compreensão, através da (re)leitura. A partir das sacadas, das fixações e do próprio percurso do olhar, é possível obter informações refinadas sobre o comportamento do tradutor em diferentes fases de seu processo de trabalho.

Após a fase on-line de obtenção de dados, ou seja, aquela que ocorre no decorrer da tarefa, para completar as três análises a serem trianguladas posteriormente, o experimentador aplica um questionário sobre a tarefa ou estimula o participante a descrever os passos seu desempenho. A essa descrição, chamamos protocolo verbal. Quando há intervenção do experimentador, classificamos o protocolo como orientado. Por meio da análise dos relatos, busca-se aferir a capacidade metareflexiva do tradutor de modo a ilustrar como a atividade metacognitiva e o comportamento autorregulatório guiam o tradutor no esforço de processamento. Apesar das críticas que esse tipo de paradigma pode receber devido à facilidade de manipulação do relato pelo participante, os protocolos têm papel importantíssimo quando implementados em conjunto com métodos on-line, pois, ao confrontar os dados de ambos, é possível validar os resultados obtidos experimentalmente.

\section{1}

\section{Expertise e experiência}

Experiência e expertise, de modo geral e de maneira equivocada, são considerados termos intercambiáveis, pois entende-se que o profissional com ampla 
experiência é aquele capaz de reproduzir um desempenho experto ao realizar uma tarefa específica. No entanto, embora a experiência numa determinada área ou tarefa possa ser considerada um dos fatores determinantes do desempenho experto, há outros fatores que podem vir a corroborar um desempenho experto, de modo que torna-se interessante do ponto de vista experimental objetivar a caracterização dos diferentes níveis de relevância desses aspectos no desenvolvimento da competência experta.

A experiência como fator primordial para a consolidação do conhecimento experto é defendida por Ericsson (2000), que argumenta em favor da prática deliberada em seu estudo sobre o desempenho de intérpretes como atividade determinante para aquisição de conhecimento experto. Por prática deliberada, entende-se "o engajamento em atividades desenvolvidas para fins específicos, desenvolvidas sob supervisão, com o objetivo de aumentar níveis de desempenho" (Ericsson, 2000). Com base nesse conceito, inclusive, Shreve (2006) afirma que ocorrem mudanças cognitivas em tradutores que desenvolvem expertise após dez ou mais anos de prática em domínio específico. Todavia, a própria natureza desse tipo de fenômeno, fragmentado ao longo de períodos extensos de tempo, é de difícil observação e testagem. Uma das perguntas centrais que podem ser colocadas, afinal, é: quais são as características dessa prática que ocorre em dez ou mais anos? Seria a prática pura e simples, sem nenhum viés de organização, capaz de resultar em desempenho experto por parte de um indivíduo?

Segundo Ericsson e colaboradores (2006), o desempenho experto é resultado de uma mudança gradativa das capacidades cognitivas que culmina no desempenho de alto nível do indivíduo. Isso só é possível através da prática deliberada e compreende altos níves de atividade metacognitiva e comportamento autorregulatório. A explicação para continuados níveis de excelência, mesmo em situações desafiadoras pela sua complexidade e crescente dificuldade, estaria na metacognição e na autorregulagem do indivíduo. Dessa forma, Shreve (2006) pressupõe que tradutores expertos apresentem características cognitivas comuns a expertos em outras áreas. Sirén \& Hakkarainen (2002) apresentam resultados de um experimento com quatro tradutores expertos e dois tradutores não expertos. Os dados obtidos por eles indicam que a tradução é na realidade uma tarefa de resolução de problemas apresentando mais de uma solução, conferindo a ela um 
status e um nível de dificuldade ímpares, corroborando o que foi aventado por Gerloff (1988 apud Siren \& Hakkarainen, 2002) e ficou conhecido como "o problema de a tarefa (tradução) não ficar mais fácil mesmo quando o indivíduo adquire experiência ou expertise".

Não se pode afirmar, no entanto, que na literatura haja um grande número de estudos empírico-experimentais relativos ao processo tradutório que aborde a expertise. Dentre os existentes, destaco os estudos de Jakobsen (2002) e Alves (2005), que distinguem os perfis de tratudores aprendizes e tradutores profissionais, do grupo PACTE (2005), que compara tradutores profissionais e professores de língua estrangeira, e de Silva (2007), que pesquisa o desempenho de experts em determinados assuntos. É interessante ressaltar que Silva (2007) assume serem relevantes não só os estudos que focam em tradutores profissionais ou expertos, mas também aqueles referentes a diferentes perfis de desempenho em tradução, como o de estudantes de língua estrangeira, bilíngues, não tradutores e tradutores iniciantes, profissionais e tradutores expertos.

Como visto até agora neste capítulo, pode-se afirmar com certa tranquilidade que a aproximação entre os campos dos estudos em expertise e desempenho experto e dos estudos empírico-experimentais em tradução é relativamente recente. E embora avanços significativos tenham sido feitos nessa interface, fica patente que as pesquisas na área ainda gozam de muito fôlego e, em alguns aspectos, parecem ter um grande caminho de desenvolvimento metodológico no encalço do avanços tecnológicos inerentes a esse tipo de pesquisa. Um dos caminhos mais naturais a serem seguidos nesse tipo de pesquisa, como demonstrado por Silva (2007) no parágrafo anterior, é a caracterização do conhecimento experto de diferentes sujeitos-tradutores, sejam eles tradutores de fato ou por circunstância, e do conhecimento inerente a diferentes modalidades tradutórias, haja vista que temos uma diferença muito grande no que tange o processo tradutório de profissionais ligados a diferentes áreas, como a tradução técnico-científica, a tradução audiovisual, a tradução juramentada etc, afinal, as competências exigidas por cada uma dessas áreas pode variar enormemente.

Neste trabalho especificamente, os conceitos de expertise e experiência são discutidos no âmbito de uma abordagem empírico-experimental do processo 
tradutório para legendagem, ao comparar o desempenho de legendadores e não legendadores em tarefas que visam a obter informações sobre a maneira que os sujeitos lidam com a segmentação textual interna de legendas. Com os experimentos, tenho o objetivo de caracterizar padrões gerais que envolvem o processo estudado, comparar e contrastar o desempenho de profissionais e leigos e discutir, com base nos dados, o papel da experiência e da expertise nos desempenhos dos grupos. Com a pesquisa realizada pretendo contribuir para os estudos da área ao abordar uma modalidade subexplorada, a tradução para legendagem, mais especificamente a habilidade de segmentação textual, parte essencial nesse tipo de tradução, definidora da qualidade final de uma tradução e objeto de discussões teórico-práticas. 
5

\section{Experimentos}

\section{1}

\section{O problema}

A segmentação textual tem um papel de extrema relevância na produção do texto para legendagem. A importância desse aspecto no processamento textual talvez seja apenas comparável ao que se verifica em textos do gênero publicitário, em que a harmonia entre texto e paratexto, ou seja, imagens, gráficos, textos auxiliares e afins, é determinante para a comunicação de uma ideia. Tal veiculação, inclusive, pode guardar semelhanças com a legendagem, como a efemeridade de propagandas na TV e de peças expostas em outdoors.

O processo de tradução para legendagem pode ocorrer de diversas maneiras, a depender da tecnologia empregada pelo tradutor, sendo esta muitas vezes uma demanda do contratante. Desde o uso de papel quadriculado para delimitação do número de caracteres, algo utilizado nos primórdios da tradução para TV, passando por traduções em processadores de texto como o Word aos mais modernos softwares e suas pré-configurações, as etapas que cada tradutor segue no seu fluxo de trabalho são em grande parte influenciadas pelo software de escolha do profissional e das exigências do cliente, como fazer ou não a marcação dos timecodes ${ }^{7}$ das legendas, receber um arquivo template que sirva de base para o trabalho, ou seja, um que contenha a transcrição do áudio original, a pré-marcação e a pré-segmnetação do texto, exigindo que o tradutor, de fato, apenas traduza. Essas idiossincrasias podem ser comparadas ao que ocorre, por exemplo, com tradutores de textos técnico-científicos que adotam uma determinada ferramenta de

\footnotetext{
7 Timecodes ou timestamps são as informações temporais que indicam os momentos de exibição e ocultação de cada uma das legendas num arquivo. $\mathrm{O}$ ato de atribuir esses valores às legendas é chamado de timecoding ou timestamping. No Brasil, é comumente chamado de timing na maioria dos estados, enquanto "marcação" é um termo mais restrito ao mercado profissional de São Paulo, principalmente entre as distribuidoras de cinema. Esse processo, em geral, é conduzido por profissionais em softwares específicos e requer além de prática, habilidade e destreza em informática.
} 
apoio ao tradutor disponível no mercado em detrimento de outras e decidem fazer uso de recursos como autocompletamento ${ }^{8}$, gerenciamento de terminologia, memória de tradução, tradutores automáticos que pré-traduzem os textos ou quaisquer outros recursos disponíveis. Todavia, no ensino da tradução, principalmente quando falamos de tradução audiovisual, de modo geral, busca-se orientar a prática deliberada dos aprendizes de modo que eles aprendam, num primeiro momento, todas as fases do processo de tradução do modo mais direto possível, ou seja, com o mínimo de intervenção de recursos avançados de ferramentas de apoio ao tradutor.

Como preconizado por alguns autores, dentre eles Díaz-Cintas (2013), a fim de alcançar a formação mais ampla possível de aprendizes, as habilidades a serem abordadas devem ser, além da tradução e de aspectos prioritariamente linguísticos, a marcação de legendas e a segmentação textual interna (dentro de uma legenda, entre linhas) e externa (entre legendas). A marcação, embora em grande medida influencie escolhas tradutórias, é uma atividade de caráter mais mecânico, sendo inclusive, muitas vezes (quando ocorre o desmembramento do processo tradutório a fim de atender diferentes demandas, dentre as quais destacam-se a agilização e a diminuição de custos do projeto) relegada a não tradutores; em geral, a técnicos da área de cinema, vídeo e TV. Destarte, a investigação desta parte do processo e seu consequente impacto, num primeiro momento, não parece ser tão frutífera quanto a da segmentação textual, foco deste trabalho.

A segmentação textual externa obedece a critérios bastante objetivos que podem ocorrer isolados ou conjuntamente (Díaz-Cintas \& Remael, 2007). São eles: i) ritmo de fala, mais especificamente a velocidade com que o interlocutor profere os enunciados e sua respiração e ii) pausas, interrupções e possíveis idiossincrasias, como gaguejos, dificuldades de fala e maneirismos. Vale lembrar que esses objetivos são sempre pautados pelo contexto imagético a que estão vinculados e estão intrinsicamente relacionados a ele. Num âmbito ainda mais detalhado da segmentação, nos deparamos com a necessidade de segmentar as legendas em linhas, geralmente duas, de até 42 caracteres cada (esses valores, atualmente, ficam entre 32 e 42 caracteres no mercado profissional, a depender da mídia). A

\footnotetext{
${ }^{8}$ Sistema que prevê o restante de uma palavra enquanto ela é digitada pelo usuário.
} 
determinação desses valores, atrelados à velocidade de leitura, visa a harmonizar uma questão de ordem visual-espacial, neste caso, a porção da tela a ser parcialmente encoberta por legendas e, ao mesmo tempo, possibilitar ao tradutor transpor o conteúdo das falas para o formato de legendas sem fazê-lo de forma telegráfica ou incoerente com o conteúdo original.

As orientações para a segmentação interna obedecem a critérios sintáticos. As propostas de Karamitroglou (1998), desde sua publicação, são utilizadas como base para o ensino e a prática da tradução para legendagem em diferentes línguas. De acordo com o autor,

"É preferível segmentar uma legenda de linha única em duas linhas, distribuindo as palavras em cada uma delas, pois os olhos e o cérebro dos espectadores identificam que uma legenda de duas linhas possui mais conteúdo e, por conseguinte, aceleram o processo de leitura." (Karamitroglou, 1998, sem página, tradução nossa) ${ }^{9}$

É interessante notar que Karamitroglou faz afirmações sobre o comportamento ocular e o funcionamento do cérebro durante a leitura. Ao passo que não é esperado um detalhamento de dados dessa natureza num texto com características de manual, não se deve deixar de observar de maneira mais crítica essas afirmações. O método experimental, aliás, como defendido anteriormente e como buscarei demonstrar na presente dissertação, provê bases adequadas para a investigação de processos de leitura, inclusive em seu nível de implementação, ou seja, no nível das estruturas cerebrais e sua ativação durante a leitura, embora esse último seja um desafio mais voltado para as empreitadas que vemos na Neurolinguística. Após discorrer sobre a importância da segmentação entre linhas e fazer as afirmações supracitadas, Karamitroglou demonstra por meio de um esquema arbóreo as preferências sintáticas que devem orientar a segmentação interna de legendas e orienta:

"O texto legendado deve ser segmentado no nó sintático mais alto possível. Isso significa que cada exibição de legenda deve conter

\footnotetext{
${ }^{9}$ Do original: "It is better to segment a long single-line subtitle into a two-line subtitle, distributing the words on each line. This is because the eye and the brain of the viewers render a two-line subtitle as more bulky and, as a result, accelerate the reading process."
} 
idealmente uma frase completa. Caso a frase completa não caiba numa única linha e continue numa segunda linha ou, até mesmo, numa nova exibição, a segmentação em cada uma das linhas deve ser feita de maneira a coincidir com o nó sintático mais alto possível."10 (Karamitroglou, 1998, sem página, tradução nossa)

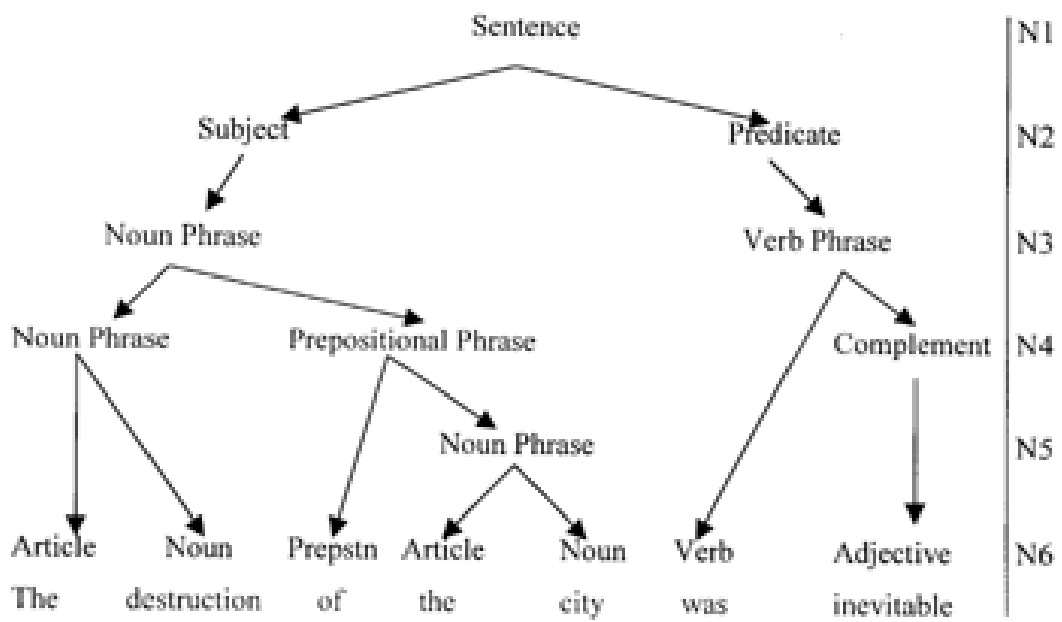

Figura 2: Exemplo de representação arbórea que orientaria segmentação das legendas, segundo proposta de Karamitroglou (1998)

Sendo assim, a segmentação ideal da frase acima seria feita no nó 2 , ou aquele que, na representação de Karamitroglou, separa a o sujeito e o predicado da sentença.

The destruction of the city was inevitable.

Uma segmentação num nível mais baixo da árvore incorreria numa quebra pouco natural para a leitura ou para uma pausa (respiração) numa fala, como no nó 5.

\section{The destruction of the \\ City was inevitable.}

\footnotetext{
${ }^{10}$ Do original "Subtitled text should appear segmented at the highest syntactic nodes possible. This means that each subtitle flash should ideally contain one complete sentence. In cases where the sentence cannot fit in a single-line subtitle and has to continue over a second line or even over a new subtitle flash, the segmentation on each of the lines should be arranged to coincide with the highest syntactic node possible."
} 
Ao seccionar o texto no nível 5 da representação arbórea, ocorre a separação do sintagma nominal "the city", formado por um artigo e um nome. Para defender sua hipótese de que a segunda segmentação é preferencial em relação à primeira, Karamitroglou prossegue:

\begin{abstract}
"Dentre as duas segmentações, a segunda é a que mais favorece o fluxo de leitura. Isso ocorre, pois quanto maior o nó sintático, maior é o agrupamento de carga semântica e de informação apresentada ao cérebro. Quando segmentamos uma sentença, forçamos o cérebro a fazer uma pausa no processamento de informação linguística momentaneamente, até que os olhos possam recuperar a próxima informação linguística. Quando a segmentação é inevitável, no entanto, devemos forçar a pausa no cérebro num ponto em que a carga semântica tenha transmitido uma informação minimamente completa." ${ }^{11}$ (Karamitroglou, 1998, sem página. tradução nossa)
\end{abstract}

Karamitroglou, mais uma vez, lança mão de dados especulativos sobre a leitura, mais especificamente do processamento de legendas, sem base empíricoexperimental, confiando em grande parte em intuições amplamente divulgadas na literatura disponível ou nos achados preliminares de d'Ydewalle (1987, 1991). No entanto, a proposta de Karamitroglou para a segmentação de legendas continua a ser adotada por professores, inclusive por mim, e por distribuidoras e programadoras de conteúdo, com pouco ou nenhum questionamento. A fim de verificar em que medida a segmentação de legendas pode ser considerada reflexo de uma intuição linguística comum que orienta a leitura e seu ritmo de maneira otimizada e natural, como sugerido por Karamitroglou (1998) ou de treinamento direcionado para lidar com a questão, ou seja, de uma competência tradutória em legendagem, desenvolvi experimento reportado na presente seção.

\footnotetext{
${ }^{11}$ Do original "Out of the two segmentations, it is the second that flows as more readable. This occurs because the higher the node, the greater the grouping of the semantic load and the more complete the piece of information presented to the brain. When we segment a sentence, we force the brain to pause its linguistic processing for a while, until the eyes trace the next piece of linguistic information. In cases where segmentation is inevitable, therefore, we should try to force this pause on the brain at a point where the semantic load has already managed to convey a satisfactorily complete piece of information."
} 


\section{2}

\section{Experimento 1}

O objetivo deste experimento foi o de comparar o desempenho de profissionais de legendagem ao de aprendizes de tradução numa tarefa de segmentação de legendas, usando um software profissional. Além de ser parte do trabalho diário de tradutores para legendagem, com o intuito de propiciar um contexto de maior validade ecológica possível, adaptei um exercício de segmentação proposto por Martinez (2007) e adotado tanto por ela quanto por mim em cursos de formação de tradutores, ou seja, o presente experimento trata-se, na realidade, de uma tarefa corriqueira para aprendizes em formação com o monitoramento necessário ao teste da hipótese que proponho.

No contexto da formação de tradutores, o objetivo da tarefa é despertar a atenção dos aprendizes para a segmentação textual das legendas convidando-os a segmentar uma tradução pronta em forma de texto corrido em legendas. Ao fornecer o texto final já pronto, a preocupação com a tradução é reduzida exponencialmente, de modo que os alunos/sujeitos podem se concentrar na habilidade foco da tarefa. Os sujeitos podem segmentar o texto da maneira que preferirem; todavia, o vídeo correspondente ao trecho de tradução os orienta em relação ao ritmo da fala. A escolha do vídeo, um trecho de narração de um narrador onisciente com fala bastante clara e pausada, foi feita a fim de não impor desafios à segmentação externa, entre legendas, de maneira a permitir que os participantes possam de fato enfocar seus esforços às instâncias de segmentação interna.

Conforme será visto na próxima seção, a tela de apresentação, dividida em três partes, exibia do lado esquerdo, um trecho da tradução do vídeo disponibilizado no processador de texto Microsoft Word. Os outros dois terços da tela eram ocupados pelo software profissional de legendagem Genius Subtitler ${ }^{\circledR}$ de maneira que células para preenchimento do texto fossem exibidas no centro da tela, e o vídeo, no canto direito. Vale ressaltar que essa apresentação é condizente com a do trabalho de um tradutor profissional, que opera simultaneamente com um software para exibição do roteiro original e outro para a tradução, revisão, em consonância com a proposta de alta validade ecológica deste trabalho. 
Trabalhei com a hipótese de que tradutores experientes têm um desempenho superior na tarefa por: i) estarem acostumados com tarefas afins que exigem habilidades e controle executivo similares (como a manipulação de vídeo e texto em paralelo) e, principalmente, ii) terem a experiência necessária para lidar com a segmentação textual e suas nuances no contexto da tradução para legendagem. Nossa previsão foi de que o grupo formado por profissionais apresentaria um desempenho substancialmente superior em todos os aspectos analisados possíveis, ou seja, teria uma menor duração da execução da tarefa e a maior porcentagem de segmentações-alvo. Ademais, era esperado que as justificativas do raciocínio que permeou as escolhas do sujeito se alinhariam com as orientações contidas em guias e manuais.

\subsection{1}

\section{Metodologia}

\section{Participantes}

Os participantes foram 20 adultos voluntários. Destes, 10 eram aprendizes de tradução que nunca haviam atuado profissionalmente como tradutores nem conheciam softwares de legendagem, formando assim o grupo não experiente. Os outros 10 eram tradutores experientes, que já haviam exercido ou exerciam a tradução profissionalmente por pelo menos cinco anos no momento da aplicação do experimento e conheciam softwares variados de legendagem (não necessariamente o software empregado), formando assim o grupo experiente. Os 10 participantes do grupo não experiente atendiam aos seguintes pré-requisitos: i) não ter cursado nenhuma disciplina de Tradução Audiovisual; ii) ter cursado ou estar cursando a disciplina Língua Inglesa: Texto e Contexto I, pré-requisito para todas as disciplinas de Tradução e Língua Inglesa na PUC-Rio. Dentre os participantes, havia 13 mulheres e 7 homens, e a faixa etária média foi de 24,5 anos. Todos receberam e assinaram termo de consentimento livre e esclarecido, cujo modelo está disponível no anexo desta dissertação. 


\section{Material}

Para conduzir o experimento, empreguei o software profissional de tradução para legendagem Genius Subtitler® (2009). A professora Sabrina Martinez e eu participamos ativamente de seu desenvolvimento como tradutores e consultores pedagógicos, pois era de nosso interesse, à época, desenvolver uma ferramenta, que além de atender as demandas de profissionais da área, possuísse recursos que facilitassem o aprendizado de novatos. O Genius Subtitler é considerado uma ferramenta WYSWIG (sigla para What You See Is What You Get), pois permite que os participantes vejam em tempo real o impacto das suas modificações nas legendas de maneira fidedigna a exibições nas mídias finais no vídeo disponibilizado ao lado direito da janela, de modo que o sujeito pode monitorar em tempo real o impacto de suas decisões.

O software foi pré-configurado para exibir uma coluna intitulada "Translation" com células para inserção do texto segmentado e outra chamada "Information control" em que são exibidas as seguintes informações: tamanho das linhas de legenda em pixels, tamanho das legendas em número de caracteres, o somatório dos caracteres e a duração da exibição da legenda, sendo o último irrelevante para a conclusão da tarefa, pois os sujeitos não precisaram lidar com a determinação de timecodes das legendas. Essa informação, todavia, por constar na mesma coluna que outras necessárias para a tarefa foi mantida, sem prejuízo para sujeito, que deveria apenas ignorar os valores zerados.

Dois vídeos foram utilizados no experimento, sendo o primeiro um trecho de 1min4s do documentário The Last Lion of Liuwa, apenas para fins de teste dos softwares e de habituação dos participantes. O vídeo utilizado para, de fato, monitorar o comportamento dos participantes foi o curta Lake Simcoe, que abre o filme 32 Short Films About Glenn Gould (Girard, 1993) e conta, na maior parte do tempo, apenas com um narrador onisciente que, em off, conta sobre sua relação com a música ainda na infância. As imagens mostram o narrador ainda criança em diferentes momentos, sentado ao piano com a mãe, à beira de um lago perto de sua casa. Há apenas duas instâncias de falas desses personagens, sem destaque, parcialmente encobertos pela trilha sonora. Nesses casos, o áudio do curta foi manipulado por um software de edição (Audacity®) a fim de encobrir as falas. No 
link http://bit.ly/2eDGHLNo, as duas versões do vídeo, original e manipulado, estão disponíveis. Isso foi feito com o intuito de permitir que os participantes dedicassem sua atenção ao texto mais linear e organizado do narrador, diminuindo as chances de perturbações de qualquer natureza. Seu ritmo pausado, por exemplo, deixa pouco ou quase nada aberto para discussão em relação à segmentação externa, fator que, a princípio, não está em jogo na tarefa. Tais manipulações não alteraram substancialmente o conteúdo do curta e foram realizadas com alto grau de sucesso, haja vista que nenhum sujeito relatou ter percebido qualquer sinal de alteração do material. A duração total do curta é de 4 min18s.

A tradução disponibilizada no processador de texto Microsoft Word foi produzida por mim a pedido da Dispositiva Produções Audiovisuais para exibição na TV a cabo. A segmentação foi desfeita e os trechos editados do áudio, mencionados acima, foram devidamente subtraídos, mantendo apenas a narração do personagem. O nível de dificuldade relativamente fácil do trecho foi mais um fator determinante para a escolha do material a fim de evitar suscitar discussões de teor tradutório que desviassem o foco da tarefa.

Os sujeitos tiveram toda a sua produção monitorada com o software Camtasia ${ }^{\circledR}$, um screen logger, software capaz de gravar em vídeo tudo o que é exibido na tela de um computador e de maneira bastante intuitiva integrá-lo a uma webcam e às imagens produzidas por ela. Embora seja empregado principalmente no desenvolvimento de vídeo-aulas e tutorias, o software atualmente tem sido adotado pela comunidade científica em pesquisas experimentais de diversas naturezas por fornecer e documentar dados registrados continuamente sem interferir no desempenho do sujeito e com custo relativamente baixo. O próprio Camtasia ${ }^{\circledR}$ foi empregado para gravar um vídeo-tutorial narrado de $2 \mathrm{~min} 37 \mathrm{~s}$ com todas as instruções da tarefa para os participantes. Este material também está disponível na pasta da pesquisa (link http://bit.ly/2eDGHLN).

A produção dos sujeitos foi monitorada, ainda, com uma webcam, com o objetivo de verificar o tempo de atenção dedicado a diferentes áreas da tela. Utilizei 
o recurso conhecido como poor man's eyetracker ${ }^{12}$ (literalmente rastreador ocular de pobre), por apresentar-se como uma opção de baixíssimo custo em relação aos rastreadores com hardware próprio. Ullrich, Wallach e Melis (2003) demonstram que a eficiência da técnica para exploração de processos atencionais, como os da presente pesquisa, é superior a 70\%. Os autores também apresentam uma revisão do emprego da técnica e fornecem justificativas para adotá-la em diferentes paradigmas. No que tange os processos atencionais, com base em minha experiência profissional, prevejo que a dedicação do foco de atenção dos legendadores será muito mais no texto de partida, em detrimento das outras seções da tela. Para aferir o tempo dedicado às diferentes àreas de interesse, empreguei o cronômetro gratuito disponível no site http://online-stopwatch.chronme.com. Ele permite a exportação dos dados para o formato .csv, que pode ser manipulado no Microsoft Excel, facilitando a análise de dados.

Todos os participantes utilizaram o Headset Microsoft Life Chat LX 3000 durante a realização da tarefa e para gravar seus relatos retrospectivos. Os experimentos foram conduzidos num Notebook Dell com Windows 7 e mouse. O aspecto final do paradigma pode ser visto abaixo.

\footnotetext{
${ }^{12}$ Trata-se, originalmente, de um recurso que envolve uma caixa de madeira com quadrantes onde são colocados objetos diferentes. Uma webcam discretamente colocada no centro da caixa grava os movimentos oculares dos participantes que, em resposta a estímulos linguísticos, interagem com os objetos na caixa. $O$ nome da técnica hoje é empregado amplamente aos diferentes recursos que visam a reduzir custos e/ou limitações técnicas dos paradigmas que, normalmente, envolveriam rastreadores oculares modernos.
} 


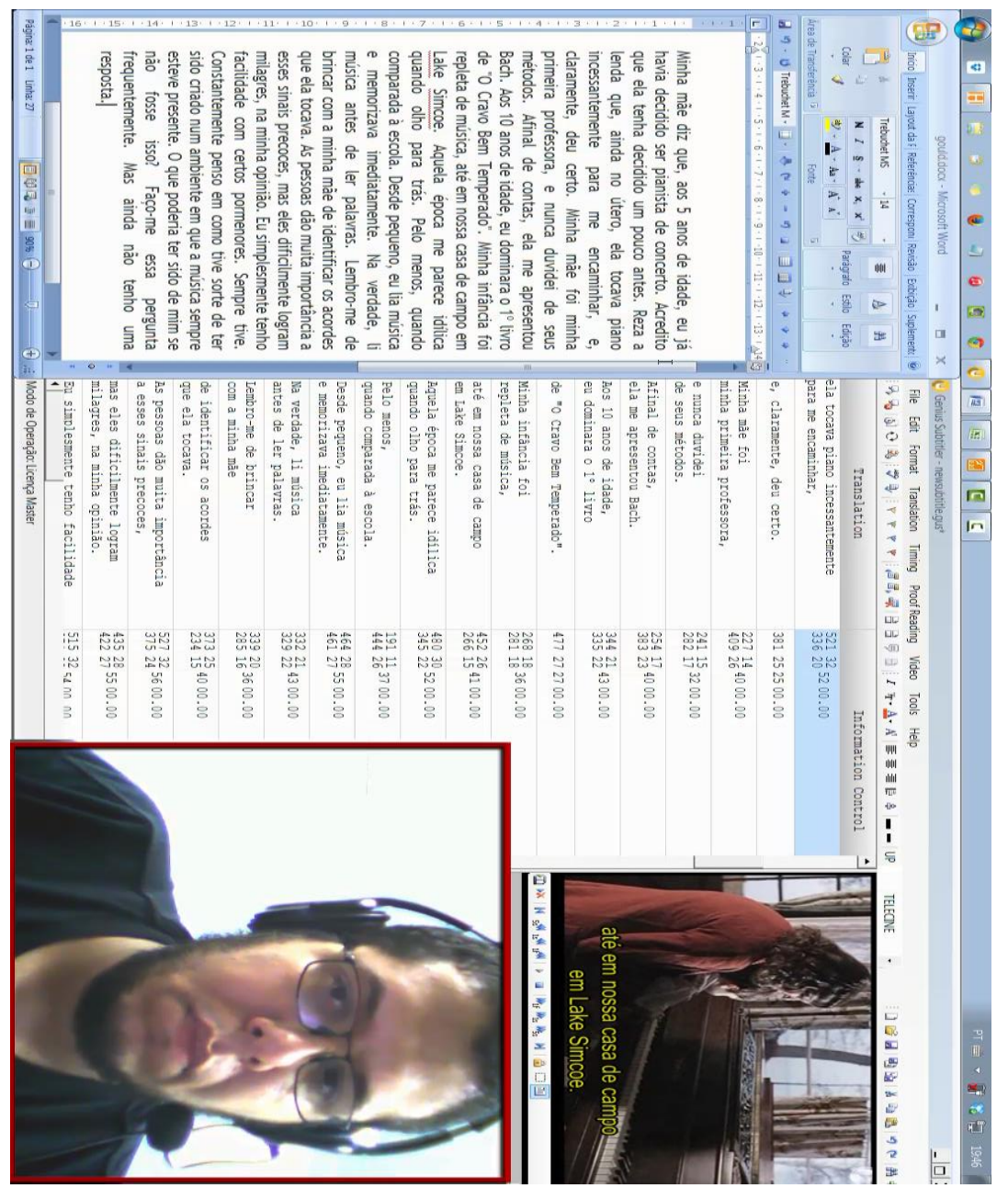

Figura 3: representação da tela utilizada para análise, em que vemos a captura de tela do software Genius Subtitler e, no canto inferior direito, a imagem captura da webcam.

Um questionário escrito com 11 perguntas sobre os perfis dos sujeitos (disponível no link http://bit.ly/2eDGHLN), seus hábitos quanto à programação legendada e impressões gerais sobre a tarefa foi preenchido pelos participantes ao final da tarefa.

\section{Procedimento}

Primeiro, os participantes assistiram ao vídeo-tutorial de $1 \mathrm{~min} 30$ s com todas as instruções da tarefa. Após essa etapa, eles tiveram espaço para manifestar dúvidas sobre o que deveriam fazer. Sanadas quaisquer dúvidas existentes, os participantes passavam por uma fase de habituação/treino em que faziam uma tarefa idêntica a considerada no teste. Em seguida, os participantes tiveram mais uma oportunidade de tirar dúvidas antes de, de fato, iniciar o teste. 
A narração do vídeo-tutorial era a seguinte:

"Olá, obrigado por participar deste experimento. Sua contribuição é inestimável para este trabalho. Agora, você assistirá um breve exemplo da tarefa que deverá concluir. Caso tenha alguma dúvida, não se preocupe. Durante a fase de explicação, você poderá se dirigir a mim a qualquer momento. Na metade esquerda da tela, você terá à sua disposição a tradução das falas de um filme em uma janela do Word, e na metade direita, um software de legendagem. Nesta tarefa, você deve transcrever a tradução da tela à esquerda em forma de legendas no software de legendagem. As legendas devem obedecer a dois critérios: o primeiro é o limite de caracteres em uma legenda de uma linha, que é 28 caracteres, e o segundo critério é o limite de caracteres em duas linhas, 32 caracteres por linha, com o total de 64 caracteres em uma única legenda. $\mathrm{Na}$ coluna Information Control, o software indicará o número de caracteres digitados por linha e o número total de caracteres da legenda. Os comandos para tocar, parar, avançar e retroceder o vídeo estão localizados na parte superior esquerda do teclado. Para criar uma legenda, basta pressionar a tecla Enter. Fique a vontade para tirar qualquer dúvida agora. Antes de começarmos, faremos um treino para você se familiarizar com a tarefa."

Ao ultrapassar o limite de 32 caracteres, o software indica o valor em vermelho na coluna "information control", não sendo permitido criar linhas de legenda com mais de 32 caracteres. O número de caracteres por linha foi delimitado com base nos parâmetros da confecção da tradução para TV a cabo que orientaram a produção da tradução disponibilizada na tarefa.

Segundo, os participantes deviam transcrever a tradução da janela do Microsoft Word à esquerda da tela de exibição nas células de texto do Genius Subtitler de acordo com o ritmo da fala dos personagens no vídeo, que podia ser manipulado, reproduzido, avançado, pausado ou retrocedido, através de atalhos pré-configurados de teclado que foram apresentados no vídeo introdutório. A tarefa não possuía limite de tempo, de modo que os participantes eram instruídos a respeitar o próprio ritmo. Como não havia necessidade de pesquisa, todos também foram instruídos a não efetuar mudanças entre janelas do Windows.

Terceiro, os participantes comunicavam ao pesquisador quando tivessem encerrado a tarefa. Após uma breve pausa, o pesquisador fazia as perguntas préestabelecidas sobre a tarefa (disponíveis no link http://bit.ly/2eDGHLN). Considero importante frisar que os participantes tinham liberdade para expandir suas respostas 
e comentar fatos não diretamente relacionados com a pesquisa, preservando o máximo de espontaneidade nesse momento.

\section{2 .2}

\section{Resultados e discussão}

Os dados produzidos pelos participantes foram analisados segundo os seguintes parâmetros

i) escore de desvios de segmentação preferenciais (gráfico 1);

ii) duração da tarefa (gráfico 2);

iii) movimentação do olhar/alocação da atenção entre as duas áreas de interesse: texto original (A1) e texto segmentado e vídeo (A2) (gráfico 3) - a fim de investigar padrões atencionais dos grupos ${ }^{13}$;

A análise dos dados foi complementada por protocolos verbais guiados póstarefa. Discutimos em que medida a experiência em tradução de legendas influencia a segmentação do texto e em que medida o comportamento dos aprendizes de tradução se aproxima das orientações ensinadas em cursos de tradução e são reforçadas por grandes clientes no mercado de Tradução Audiovisual, as quais são tidas como reflexo de processos naturais de leitura. No link http://bit.ly/2eDGHLN, encontram-se os seguintes dados obtidos com a participação dos voluntários: texto segmentado em forma de legendas, tempo de duração da tarefa e transcrição dos protocolos verbais.

Os escores foram estabelecidos a partir de uma divisão simples do número de desvios de segmentação pelo número de linhas, ou seja, o número de segmentações possíveis no texto-alvo. Por exemplo, o participante 4 do grupo não

\footnotetext{
${ }^{13}$ Devido às limitações da técnica utilizada para o registro da movimentação ocular, optei por apenas duas áreas de interesse. A qualidade de imagem dos vídeos normalmente disponilizados para servições de legendagem assim como o espaço secundário ao qual o vídeo é relegado em diferentes softwares de tradução, todavia, demonstra uma tendência a diminuir o papel da imagem no processo tradutório.
} 
experiente cometeu 8 desvios em 55 linhas de legenda, tendo seu escore determinado a partir do cálculo $8 / 55=0,14$. A decisão de adotar um escore ao invés de uma medida fixada com base na tradução-modelo foi motivada pela possibilidade de admitir segmentações que desviassem do texto-base sem desrespeitar as regras sugeridas por Karamitroglou (1998).

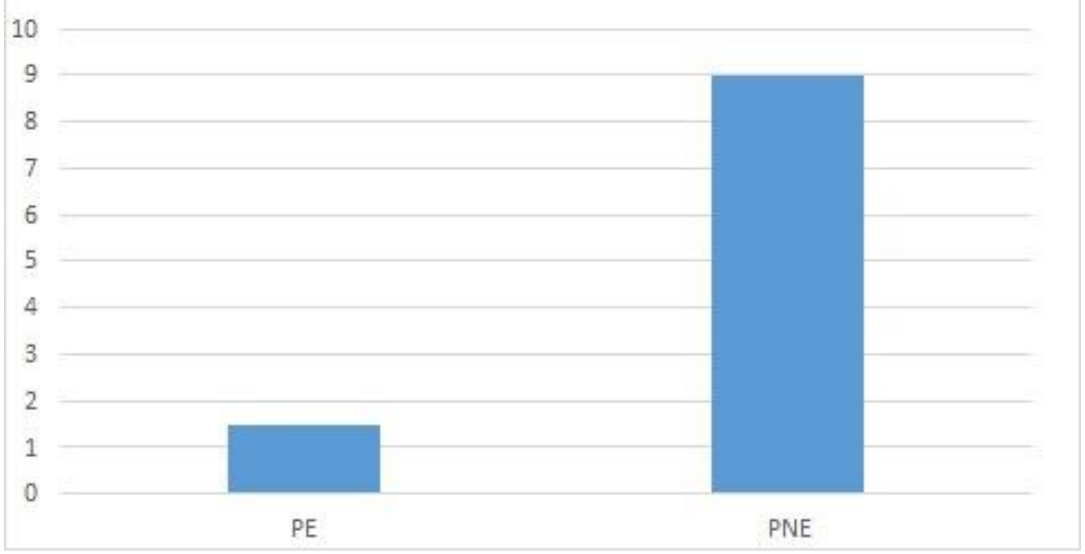

Gráfico 1: Escore de desvios de segmentação.

Nas páginas seguintes, apresento a tradução-modelo completa e, a título de exemplificação, as segmentações feitas por um participante de cada grupo. A transcrição completa dos dados encontra-se no link http://bit.ly/2eDGHLN. Destaco em vermelho as segmentações que desviaram do alvo. 


\begin{tabular}{|l|}
\hline Minha mãe diz que, \\
\hline aos 5 anos de idade, \\
\hline eu já havia decidido \\
\hline ser pianista de concerto. \\
\hline \\
\hline Acredito que ela tenha decidido \\
\hline um pouco antes. \\
\hline \\
\hline Reza a lenda que, \\
\hline ainda no útero, \\
\hline \\
\hline ela tocava piano incessantemente \\
\hline para me encaminhar, \\
\hline \\
\hline e, claramente, deu certo. \\
\hline \\
\hline Minha mãe foi \\
\hline minha primeira professora, \\
\hline
\end{tabular}

\begin{tabular}{|l|}
\hline Desde pequeno, \\
\hline eu lia música e memorizava \\
\hline imediatamente. \\
\hline \\
\hline Na verdade, \\
\hline li música antes de ler palavras. \\
\hline \\
\hline Lembro-me de brincar \\
\hline com a minha mãe \\
\hline \\
\hline de identificar os acordes \\
\hline que ela tocava. \\
\hline \\
\hline As pessoas dão muita importância \\
\hline a esses sinais precoces, \\
\hline \\
\hline mas eles dificilmente \\
\hline logram milagres, \\
\hline \\
\hline uma resposta. \\
\hline na minha opinião. \\
\hline \\
\hline Eu simplesmente tenho facilidade \\
\hline com certos pormenores. \\
\hline \\
\hline Sempre tive. \\
\hline \\
\hline Constantemente penso pergunta \\
\hline em como tive sorte \\
\hline de ter sido criado \\
\hline num ambiente \\
\hline \\
\hline sem que a música \\
\hline \\
\hline
\end{tabular}

Original

Figura 4: segmentação original das legendas do experimento 1 


\begin{tabular}{|l|}
\hline Minha mãe diz que, aos \\
\hline 5 anos de idade, \\
\hline \\
\hline eu já havia decidido ser \\
\hline pianista de concerto. \\
\hline \\
\hline Acredito que ela tenha \\
\hline decidido um pouco antes. \\
\hline \\
\hline Reza a lenda que, \\
\hline ainda no útero, \\
\hline \\
\hline ela tocava piano \\
\hline incessantemente para \\
\hline \\
\hline me encaminhar, e, \\
\hline claramente, deu certo. \\
\hline \\
\hline Minha mãe foi minha \\
\hline primeira professora, \\
\hline \\
\hline e nunca duvidei de seus métodos. \\
\hline Afinal de contas, \\
\hline \\
\hline ela me apresentou Bach. \\
\hline \\
\hline Aos 10 anos de idade, \\
\hline eu dominara o $1^{\circ}$ livro \\
\hline \\
\hline de "O Cravo Bem Temperado". \\
\hline Pelo menos, quando \\
\hline Minha infância foi repleta de \\
\hline música, até em nossa casa \\
\hline \\
\hline de campo em Lake Simcoe. \\
\hline Aquela época me parece idilica \\
\hline \\
\hline
\end{tabular}

\begin{tabular}{|l|}
\hline Desde pequeno, eu lia \\
\hline música e memorizava \\
\hline \\
\hline imediatamente. \\
\hline Na verdade, li música antes \\
\hline \\
\hline de ler palavras. \\
\hline \\
\hline Lembro-me de brincar com a \\
\hline minha mãe de identificar \\
\hline \\
\hline os acordes que ela tocava. \\
\hline \\
\hline As pessoas dão muita importância \\
\hline a esses sinais precoces, mas \\
\hline \\
\hline eles dificilmente logram \\
\hline milagres, \\
\hline \\
\hline na minha opinião \\
\hline \\
\hline Eu simplesmente tenho \\
\hline facilidade com certos \\
\hline \\
\hline pormenores. \\
\hline Sempre tive. \\
\hline \\
\hline Constantemente penso em como \\
\hline tive sorte de ter sido criado \\
\hline uasco-me essa pergunta \\
\hline num ambiente em que a m sica \\
\hline sempre esteve presente. \\
\hline \\
\hline se que poderia ter sido de mim \\
\hline \\
\hline
\end{tabular}

\section{Exemplo de sujeito não experiente}

Figura 5: segmentação das legendas do experimento 1 por sujeito não experiente 
Exemplo de sujeito experiente

\begin{tabular}{|l|}
\hline Minha mãe me diz que, \\
\hline aos 5 anos de idade, \\
\hline eu já havia decidido ser \\
\hline pianista de concerto. \\
\hline \\
\hline Acredito que ela \\
\hline tenha decidido um pouco antes. \\
\hline \\
\hline Reza a lenda que, \\
\hline ainda no útero, \\
\hline \\
\hline ela tocava o piano \\
\hline incessantemente \\
\hline \\
\hline para me encaminhar, \\
\hline \\
\hline e, claramente, \\
\hline deu certo. \\
\hline quando comparada à escola. \\
\hline Minha mãe foi \\
\hline quinha primeira professora, \\
\hline \\
\hline ela época me parece idilica \\
\hline ela munca apresentou Bach. \\
\hline de seus métodos. \\
\hline \\
\hline Aos 10 anos de idade, \\
\hline de música, \\
\hline eu domossa casa de campo \\
\hline 0 Cravo Bem Temperado". \\
\hline
\end{tabular}

\begin{tabular}{|l|}
\hline Desde pequeno, eu lia música \\
\hline e memorizava imediatamente. \\
\hline \\
\hline Na verdade, li música \\
\hline antes de ler palavras. \\
\hline \\
\hline Lembro-me de brincar \\
\hline com a minha mãe \\
\hline \\
\hline de identificar os acordes \\
\hline que ela tocava. \\
\hline \\
\hline As pessoas dão muita importância \\
\hline a esses sinais precoces, \\
\hline \\
\hline mas eles dificilmente logram \\
\hline milagres, na minha opinião. \\
\hline \\
\hline Eu simplesmente tenho facilidade \\
\hline Com certos pormenores. \\
\hline \\
\hline Sempre tive. \\
\hline \\
\hline Constantemente penso \\
\hline em como tive sorte \\
\hline \\
\hline de ter sido criado \\
\hline num ambiente \\
\hline \\
\hline em que a música \\
\hline sempre esteve presente. \\
\hline \\
\hline frequentemente. \\
\hline sue poderia ter sido de mim \\
\hline uma resposta. \\
\hline
\end{tabular}

Figura 6: segmentação das legendas do experimento 1 por sujeito experiente 
Dentre as segmentações em desacordo com a proposta de Karamitroglou (1998), salientadas em vermelho nas figuras acima, podemos ver ocorrências variadas, sendo a quebra de sintagmas nominais e preposicionais as mais frequentes.

O tempo que cada um dos grupos dedicou à tarefa foi cronometrado e as medidas individuais assim como as médias dos grupos podem ser vistas abaixo.

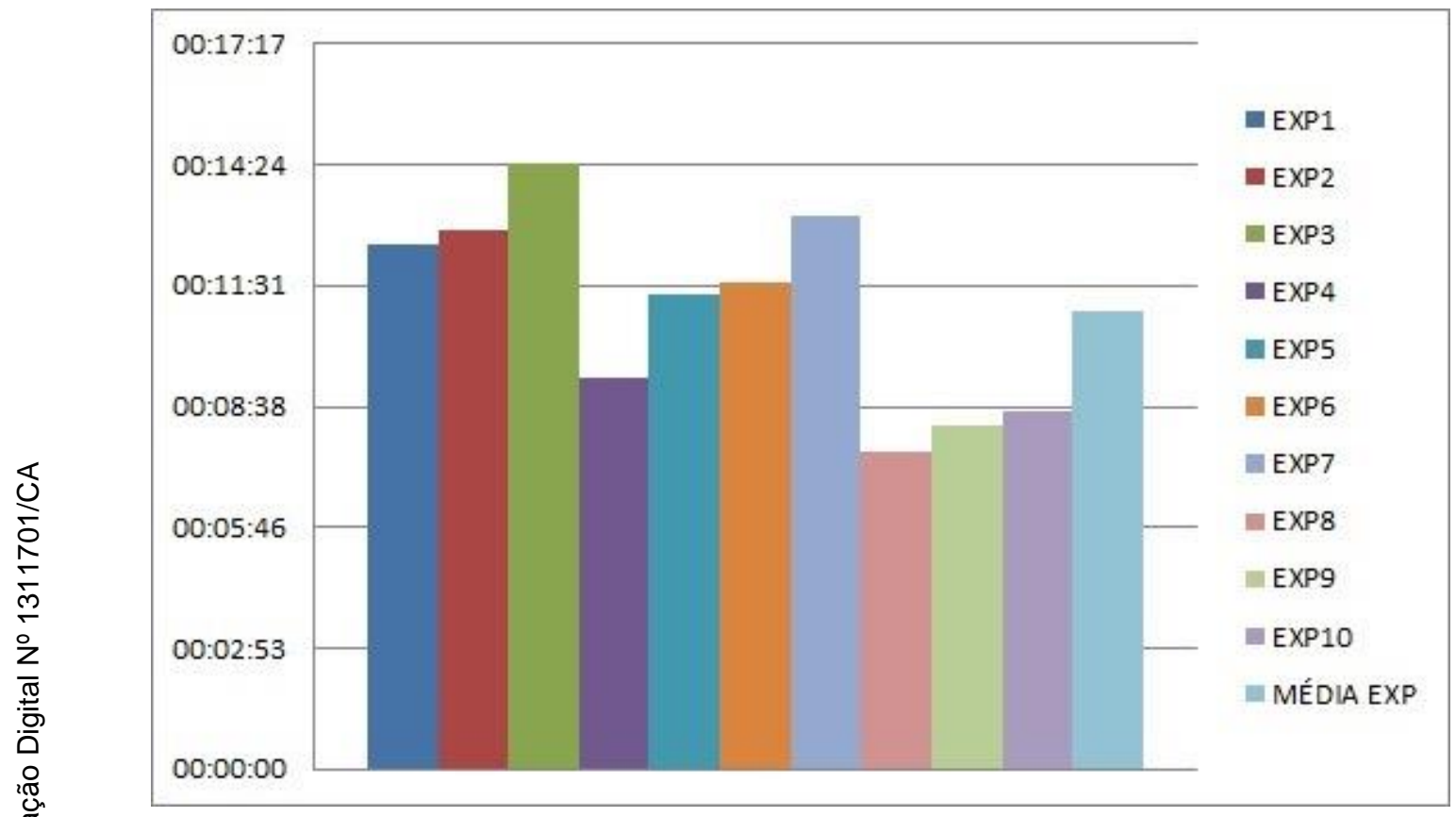

Gráfico 2: Tempo de execução da tarefa por participantes experientes 


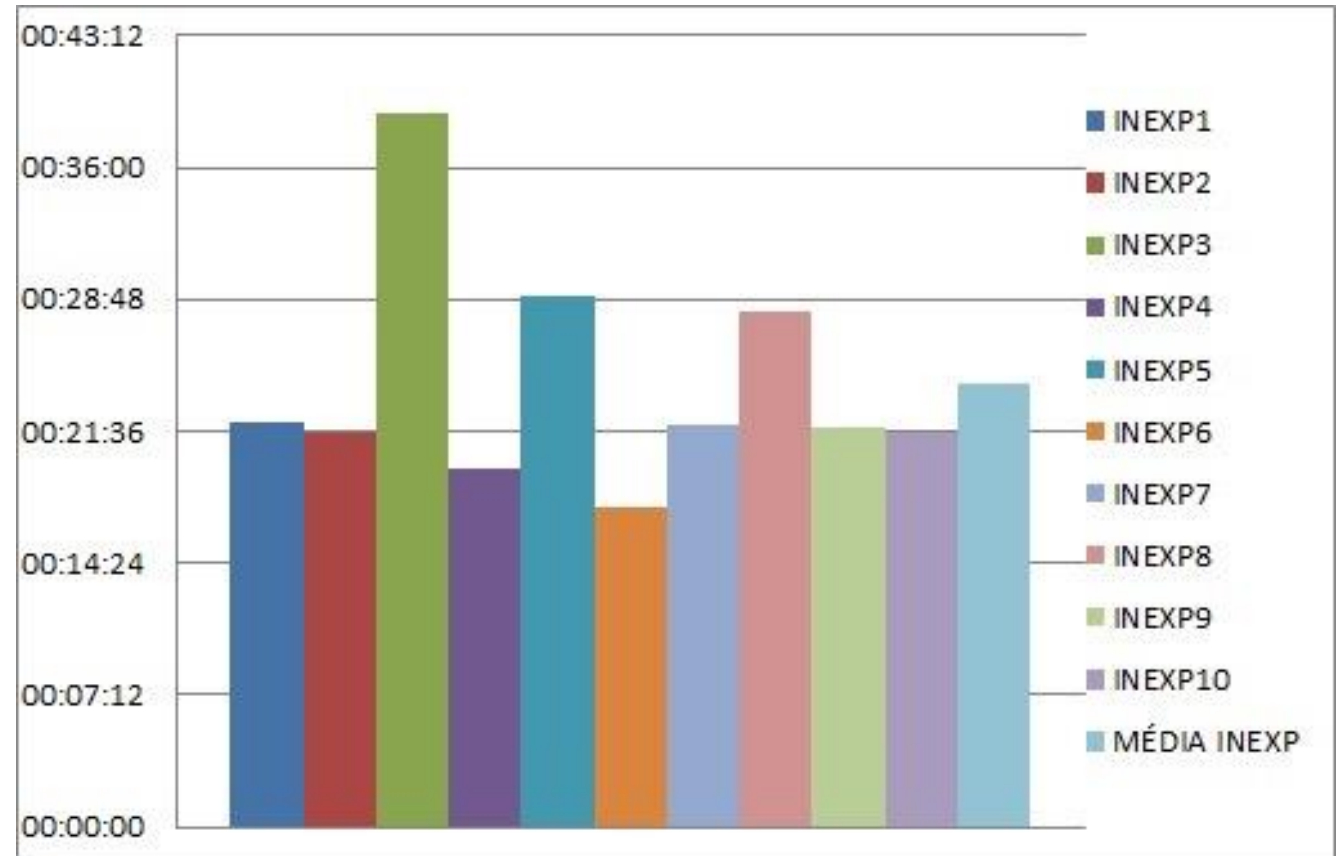

Gráfico 3: Tempo de execução da tarefa por aprendizes

O grupo dos participantes experientes foi consistentemente superior no que diz respeito ao tempo para concluir a tarefa. A facilidade dos aspectos técnicos que envolviam a tarefa, como o preenchimento das células de texto e o controle do vídeo e a presença de uma fase de treino para que os participantes se acostumassem à tarefa, nos leva a crer que a diferença entre ambos os grupos se deve, em grande parte, ao nível de desempenho na segmentação linguística. A dificuldade atribuída à tarefa pode ser mais bem compreendida ao analisarmos os dados dos protocolos verbais ainda nesta seção.

O tempo que cada um dos grupos dedicou sua atenção ao longo da tarefa também é bastante ilustrativo das diferenças entre os grupos. A tela foi dividida em duas áreas de interesse, A1, ocupada pelo texto original, e A2, ocupada pelo Genius Subtitler, predominantemente, pela tela de exibição de vídeo legendado e pelas colunas para inserção, manipulação e controle das legendas. A área de interesse 1 (A1), o texto original, recebeu menos atenção de ambos os grupos, todavia os participantes não experientes, por sua vez, dedicaram uma quantidade de tempo relativamente alta à área 2 (A2), composta pelas células para segmentação textual e pelo vídeo no Genius Subtitler, quando comparado ao grupo de tradutores experientes. 


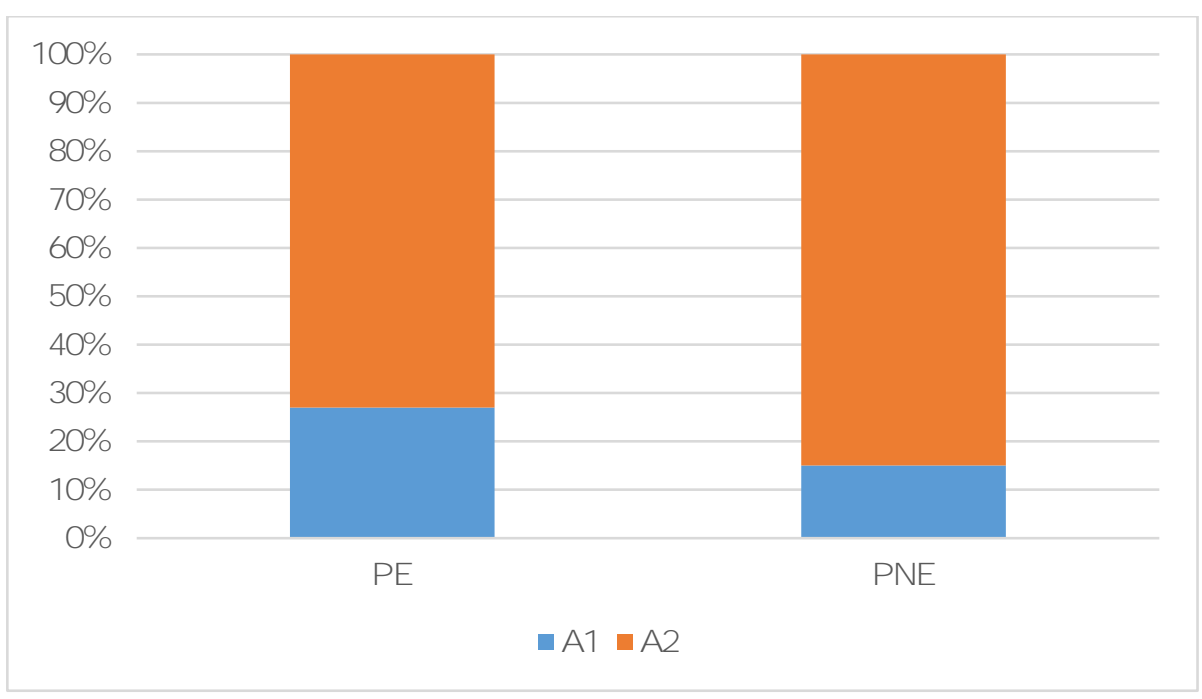

Gráfico 4: Porcentagem de tempo de atenção dedicada às áreas de interesse A1 (texto original) e A2 (célula para segmentação textual e vídeo) pelos dois grupos de participantes.

Os dados obtidos no experimento 1 permitiram uma análise estatística por meio da aplicação do teste ANOVA. O desenho possível foi de dois fatores, sendo um intragrupal e o outro, intergrupal. Todas as interações possíveis foram altamente significativas. $\mathrm{O}$ fator área de interesse teve seus valores finais em $\mathrm{F}(1,18)=102$ $\mathrm{p}=0,000001$; $\mathrm{o}$ fator experiência ficou da seguinte maneira $\mathrm{F}(1,18)=40,6$ $\mathrm{p}<0,000005$ e, ao relacionar os dois fatores, temos ainda mais uma interação significativa $F(1,18)=26,1 \mathrm{p}<0,000073$. A diferença significativa entre os grupos investigados no que se refere à atenção dispensada a cada uma das áreas é corroborada pelos relatos dos tradutores experientes, que disseram antecipar grande da segmentação apenas com base no texto-fonte, como discutido ainda nesta seção.

Os resultados do experimento 1 apresentam evidências a favor da hipótese de trabalho, haja vista que a superioridade do grupo experiente se confirmou. Embora tenha sido esperado, ou seja, tenha apresentado superioridade do grupo com experiência profissional, houve uma disparidade muito grande entre os grupos quanto ao desempenho, haja vista que todas as interações foram estatisticamente relevantes com valores de $\mathrm{p}$ muito abaixo de 0,5 .

Dois fatores recorrentes chamaram atenção no relato do grupo de aprendizes: o nível de dificuldade atribuído à tarefa e a relevância da pontuação no texto de partida. Quanto ao primeiro fator, o grupo pareceu razoavelmente dividido, entre ter considerado a tarefa fácil ou difícil. Aqueles que a consideraram difícil o 
fizeram com base nos aspectos técnicos da tarefa, principalmente a manipulação do software de legendagem, não de questões linguísticas/tradutórias, como ilustrado pelo comentário do participante 3 do grupo "Então não é impossível, mas tem um grau de dificuldade que as pessoas não imaginam que seja, assim, alto", surpreso com o processo de criação das legendas. Por outro lado, o participante 9 do mesmo grupo destacou a simplicidade da tarefa quando percebida a relação entre o áudio e o texto traduzido de maneira já otimizada para o formato de legendas. "Eu não tive nenhuma dificuldade muito grande enquanto eu tava realizando essa tarefa, porque, eu não sei, o jeito que o cara fala é praticamente a divisão que eu tive de fazer na legenda, então foi tranquilo. Não tive grandes dificuldades, não.” O participante 4 confirma o relato citado: "Eu fui olhando o que ele falava e fui vendo que os cortes estavam bem feitos, assim, na tradução, então deu pra dividir certinho.” Ambos os relatos, que ecoam os de seus pares, reforçam a importância do texto-fonte e sua pontuação para a realização da tarefa, como relatado pelos participantes 6 e 7 respectivamente. "Pontuação gráfica me ajudou certamente. Se tem duas vírgulas, por exemplo, eu gosto de colocar o segmento inteiro junto, não partir ele ao meio" e "A pontuação também foi um fator importante. Por exemplo, nesse aqui 'o que poderia ter sido de mim se não fosse isso'... Já me leva a parar e fazer outra. Mesmo que na fala ele não pare."

Pode-se concluir com base nos relatos que a segmentação externa, ou seja, entre legendas, aquela que em maior parte é orientada pelo ritmo da fala e sua relação com a pontuação do texto, é de compreensão relativamente fácil e natural. Todavia, o distanciamento das normas pretendidas no que diz respeito à segmentação interna, demonstra que esse aspecto, a princípio, não seria tão fácil quanto o primeiro.

O grupo de participantes com experiência em legendagem, por outro lado, confirmou sua facilidade na execução da tarefa através dos protocolos verbais, como relatado, mas não somente, pelos participantes 13 e 17, respectivamente: “Tava bem simples. Minha maior dificuldade foi só a configuração do teclado mesmo, porque de resto era tudo muito simples." e "Achei fácil. Porque o texto já tá ali, você não precisa resumir nem nada, é pra colocar exatamente o que tá ali." O fator que chamou mais atenção, todavia, foi a aparente capacidade do grupo experiente de prever as segmentaçãoes mais adequadas com base apenas no 
conteúdo do texto original e sua pontuação, sendo capaz, inclusive, de manipular o texto antes de assistir ao vídeo, utilizando-o apenas para confirmar suas predições de segmentação, como destacado pelos participantes 20, 18 e 13 respectivamente: “eu às vezes até antecipei um pouco o texto, já sabendo que o áudio está para entrar, mas depois eu tentei evitar fazer isso.”; “...acabei indo mais pelo texto, já que tem mais pausa na fala dele. Em geral é pela pontuação, pela estrutura das orações e tal." e "Pelo texto, eu já tinha uma ideia de como seria a segmentação, aí, quando eu não tinha muita certeza, eu ouvia o vídeo, só pra garantir.”

O experimento 1, tendo sido aplicado com sucesso, nos permitiu alcançar algumas conclusões parciais além de trazer dados básicos para iniciarmos a investigação da segmentação textual e seu impacto no processamento. Destaco, aqui, três pontos relavantes dessas conclões: i) o funcionamento do paradigma que, embora não fosse totalmente inovador, possuía caráter próprio e desafios técnicos e metodológicos; ii) o fato de os dados terem corroborado a hipótese que o grupo de tradutores experientes teria um desempenho muito superior em relação ao grupo de aprendizes e iii) um possível apontamento para a existência e a prevalência de um conhecimento experto relacionado à capacidade de segmentação textual, a princípio restrita à legendagem, com base apenas no conteúdo e na forma do texto de partida, permitindo agilizar a etapa de segmentação e empregar áudio e vídeo apenas para confirmar uma possível "pré-segmentação".

Dessa maneira, decidimos fazer um novo experimento, ainda explorando as possibilidades do paradigma sugerido no experimento 1 , na tentativa de obter informações mais detalhadas, desta vez, dando ainda mais ênfase à segmentação interna, objeto central desta pesquisa. 


\section{3}

\section{Experimento 2}

O experimento 2 manteve alguns aspectos do experimento 1, como o emprego do software de legendagem para a realização da tarefa, a organização dos grupos e a maneira como os dados foram capturados, ou seja, com o emprego do software Camtasia, uma webcam e protocolos verbais. Dois grandes diferenciais deste experimento foram: i) a tarefa em si, a revisão de um arquivo de legendas, ao mesmo tempo mais simples do ponto de vista técnico e mais informativa do ponto de vista linguístico e ii) o emprego de sentenças que poderiam gerar efeito garden path categorizadas em 3 tipos diferentes. A decisão de usar essa estrutura foi embasada em seu caráter desafiador do ponto de vista do processamento e a possibilidade de fornecer informações mais detalhadas e de uma natureza diferente (uma tarefa de compreensão com vistas à revisão) sobre sua caracterização.

Algumas limitações práticas na aplicação do experimento me obrigaram a trabalhar com uma amostra de 10 participantes, sendo 5 para cada um dos grupos, exatamente metade do número de participantes do experimento 1 .

\subsection{1}

\section{Metodologia}

\section{Participantes}

Os 10 participantes, 6 mulheres e 4 homens, com média de idade de 23 anos, divididos igualmente entre os grupos de legendadores e de aprendizes, foram selecionados de acordo com suas experiências em tradução para legendagem, assim como no experimento 1. Embora o conhecimento da língua inglesa não fosse necessário no desempenho da tarefa, mantive o controle deste fator para o grupo de aprendizes, como feito na oportunidade anterior. Por outro lado, o não conhecimento da língua chinesa e seus dialetos era um pré-requisito para a participação desta fase da pesquisa. Todos os participantes assinaram um termo de consentimento livre e esclarecido em que concordavam em colaborar 
espontaneamente com a pesquisa e fornecer os dados necessários para a análise. $\mathrm{O}$ modelo do termo encontra-se no anexo desta dissertação.

\section{Material}

Similarmente ao paradigma anterior, emprego o software profissional de legendagem Genius Subtitler e o screen logger Camtasia. O vídeo escolhido para esta tarefa foi um trecho de 14 minutos e 32 segundos de um episódio de um programa jornalístico, News Probe, exibido semanalmente aos domingos pela China Central Television, maior rede pública de televisão daquele país. O tema do episódeio específico é o sistema educacional chinês. É importante observar que todo o conteúdo do vídeo, tanto aúdio quanto créditos, legendas intralinguais (uma obrigação na TV chinesa) e cartelas (texto exibido por escrito na tela) estão em chinês. O programa se assemelha, em formato e proposta, ao brasileiro Globo Repórter. Este episódio específico foi encontrado no YouTube com legendas de baixíssima qualidade em inglês. Os erros e imprecisões variavam entre questões técnicas, como sincronia, tempo de leitura e número de linhas por legenda, e problemas de concordância, digitação e até nonsense, o que me faz acreditar, mesmo não tendo nenhum conhecimento de chinês, que a qualidade tradutória das legendas também seja questionável. No entanto, as legendas permitem ao espectador acompanhar o programa de maneira razoável e compreender o que se passa com um nível satisfatório de detalhes. As legendas foram produzidas pelo usuário que fez o upload do vídeo, xingfenzhen, que não oferece informações pessoais. Acredito que isso ocorra devido ao medo de sofrer sanções por conta dos direitos autorais dos materiais que posta em seu canal, como menciona na descrição de alguns de seus vídeos. Ele descreve o conteúdo do vídeo da seguinte maneira:

\footnotetext{
"Com todo o alvoroço que se criou ao redor da educação na China por conta do Programa Internacional de Avaliação de Alunos (PISA), "mães tigresas", "momento Sputnik" etc, trago um documentário que mostra o que a China pensa sobre seu próprio sistema educacional. O começo do documentário fala sobre proibir o uso da Olimpíada de Matemática para
} 
acesso ao Ensino Médio, e o restante é sobre a melhoria de escolas rurais" 14

A primeira parte do vídeo enfoca o fim do uso das Olimpíadas da Matemática para obtenção de acesso ao ensino médio, enquanto o resto trata da reestruturação de escolas em regiões rurais.

Para a realização desta tarefa, criei 229 legendas livremente inspiradas na temática do documentário e nas legendas fornecidas pelo uploader do vídeo no Genius Subtitler, software em que também fiz a marcação de tempo delas. A marcação das legendas em uma língua cujo tradutor não domina é uma tarefa relativamente comum, não representa um grande desafio para legendadores experientes e, de modo geral, é orientada pelo ritmo da fala, pausas, respiração, ocorrências de nomes próprios facilmente identificáveis e pistas visuais, como gestos, ênfases e cortes de cena. Mesmo com um contexto favorável à criação dos itens experimentais - um vídeo em que todo o conteúdo linguístico está num idioma que os participantes não dominam -, ocorre que as próprias imagens, a necessidade de formular um texto coerente e fidedigno para os participantes e questões técnicas, como velocidade de leitura e número de caracteres por linha e por legenda acabam por configurar agentes restritivos do desenvolvimento deste material. As legendas, no entanto, foram formuladas dentro dos parâmetros propostos para a maior parte da programação do serviço de streaming Netflix. O manual de regras e normas técnicas da empresa exige legendas de até 42 caracteres por linha, e velocidade de leitura de até 17 caracteres por segundo/200 palavras por minuto para conteúdo adulto.

Dentre as 229 legendas criadas para o experimento, 12 são itens experimentais, legendas cuja segmentação favorece a interpretação de uma ambiguidade temporária do tipo garden-path. Essas senteças objeto de análise posteriror foram classificadas de acordo com suas ambiguidades da seguinte maneira:

\footnotetext{
${ }^{14}$ With all this hoopla about education in China generated by the PISA exam, tiger mothers, sputnik moment etc. Here is a documentary news report that will tell you what China is thinking about talking about it's own education system. the very first part of the video focus on stop math Olympics used for middle school entrance, rest of the video is about reform rural schools.
} 
a) Complemento de verbo ou sujeito da oração seguinte (completa):

Mesmo quando os alunos estudam a matéria acumula cada vez mais.

Quando o professor percebe a conversa acaba na mesma hora.

Embora eu tenha completado o curso me causou vários traumas.

Quando os alunos chamam a professora caminha até eles sem necessidade.

b) Objeto coordenado ou oração iniciada pelo "e":

Vocês só pensam em Matemática e História fica de lado. É isso mesmo?

eu cumprimento os alunos e os professores não olham para mim.

Ele repreendeu as meninas e os meninos acharam isso injusto.

O inspetor vê os alunos e as alunas saem correndo envergonhadas.

c) Que - pronome relativo ou que - conjunção integrante (introduzindo oração completiva):

As mães contam aos alunos que estão reprovados histórias terríveis.

Os professores mostram aos alunos que passaram os gabaritos das provas.

Os pais demonstram aos professores que estão preocupados sua solidariedade,

Eu dizia para minha avó que estava triste para continuar rezando. 
As legendas continham ainda, de maneira aleatória, pequenos erros de digitação, concordância, trechos com redação pouco natural e afins com o intuito de dissimular os itens experimentais em meio à tarefa de âmbito maior, a revisão.

O experimento 2 diferencia-se do experimento 1, ainda, ao empregar o software Beyond Compare. Ele é capaz de realizar comparações e gerar arquivos relatando diferentes versões de arquivos de texto, imagem e áudio, além do conteúdo de pastas. O Beyond Compare é empregado, principalmente, no controle de alterações de softwares em processo de programação, já que permite o controle eficiente de alterações nas linhas de código das diferentes versões em sua fase de testes. Para os objetivos desta pesquisa, todavia, o software foi empregado na comparação dos arquivos manipulados pelos participantes com o arquivo-fonte a fim de obter um relatório detalhado de todas as alterações feitas por cada um. O Microsoft Word dispõe de recurso similar, porém seus relatórios, de modo geral, são demasiadamente herméticos.

Todos os participantes utilizaram fones de ouvido ATH-M50 da AudioTechnica durante a realização da tarefa. Os relatos retrospectivos foram capturados pelo microfone interno do notebook usado na condução do experimento, um MSI com Windows 8 e mouse.

\section{Procedimento}

Os participantes foram convidados a participar do experimento sob a prerrogativa de colaborarem com uma pesquisa sobre revisão de legendas. Durante uma conversa com o participante, um pre-âmbulo com a motivação para a tarefa era introduzido: a tradução do documentário havia sido encomendada por uma produtora de tradução audiovisual a um tradutor chinês fluente em português. Após não ter conseguido contratar um revisor bilíngue, porém ciente da qualidade de seu tradutor, a empresa dispensou a fase de revisão bilíngue, prática bastante comum, e confiou ao participante do experimento uma revisão monolíngue do material, ou seja, com enfoque no texto de chegada e aspectos como qualidade e naturalidade da redação, digitação, segmentação textual, precisão terminológica etc, e em aspectos técnicos como número de caracteres por linha. 
Dada a margem para possíveis idiossincrasias - se considerarmos o desconhecimento da língua chinesa por parte tanto dos participantes quanto do experimentador -, os participantes foram instruídos a não fazer alterações na marcação das legendas, apenas no texto, o que tornou a tarefa ainda mais fácil do ponto de vista técnico. As instruções de manipulação do software foram passadas através de um vídeo tutorial produzido no software Camtasia, nos moldes do experimento 1. A fim de evitar que os participantes ficassem cansados durante a execução da tarefa e perdessem o foco, não houve uma fase de testes prolongada, apenas a oportunidade de conhecer e se habituar aos comandos necessários no teclado e sanarem suas dúvidas antes do início da revisão. Desta vez, apenas o software de legendagem Genius Subtitler ocupava a tela de trabalho do participante que dispunha das legendas e suas respectivas informações de controle na porção esquerda da tela e do vídeo com a simulação das legendas à direita. Os participantes não receeberam limite de tempo, mas foram orientados a revisar o material numa única "passada", retomando apenas trechos específicos em que tivessem maior dificuldade, sem consultar nenhum material. A fase de treino foi dispensada dada a simplicidade da tarefa e sua extensão, evitando, assim, a extenuação dos participantes. O software Camtasia, em paralelo, gravava todo o conteúdo em tela ao longo da tarefa e o olhar do participante através de uma webcam, assim como no experimento anterior. Nesta etapa, dada a simplicidade da tarefa, decidi pela não exibição de um tutorial ou de uma fase de treino, os primeiros minutos da própria tarefa eram suficientes para que os participantes se acostumassem com os poucos comandos envolvidos na tarefa.

Terminada a revisão, os participantes eram convidados a uma fase de comentários e justificativas das próprias escolhas de revisão. Essa fase não foi comunicada de antemão aos participantes, propositalmente, a fim de evitar sua influência sobre o processo de revisão. Os participantes foram entrevistados e tiverem seu áudio captado pelo microfone integrado do notebook usado no experimento. Algumas perguntas básicas sobre o nível de dificuldade da tarefa precederam um pedido de justificativa das alterações feitas ao longo da revisão. Nessa fase, o relatório de alterações gerado pelo Beyond Compare foi utilizado para orientar o trabalho dos participantes. Caso algum item experimental não tivesse sido manipulado pelo participante, de forma que ele não constasse no relatório 
comparativo de alterações, o experimentador pedia a opinião do participante quanto à compreensão do trecho e oferecia a oportunidade de alterar a tradução desses itens excepcionalmente, propiciando uma reflexão mais profunda de um item que, a princípio, tivesse sido ignorado ou inalterado. Os protocolos foram conduzidos de maneira bastante livre, permitindo que o participante se posicionasse de maneira espontânea, sem medo de julgamento pelas suas escolhas.

\subsection{2}

\section{Resultados e discussão}

Os dados da produção dos participantes foram analisados sob os seguintes critérios:

i) número de sentenças-alvo alteradas;

ii) tipos de alteração - adequadas e que desfizessem a ambiguidade $\mathrm{X}$ outras -pistas contextuais evidenciavam e/ou tornavam mais plausíveis uma interpretação dentre as duas possíveis nas sentenças garden path. Foram consideradas alterações corretas aquelas que refletiam o direcionamento fornecido pelas pistas $e$ mantinham-se gramaticais.

Ex:

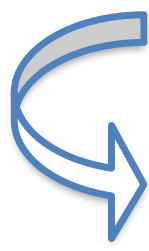

Mesmo quando os alunos estudam a matéria acumula cada vez mais.

Mesmo quando os alunos estudam, a matéria acumula cada vez mais.

Eu dizia para minha avó que estava triste para continuar rezando.

Eu dizia para minha avó, que estava triste, para continuar rezando. 


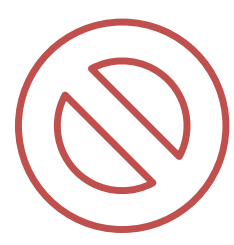

\author{
Eu dizia para minha avó \\ que estava triste para continuar rezando. \\ Eu dizia para minha avó que estava triste, \\ para continuar rezando.
}

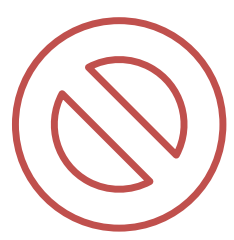

\author{
Os pais demonstram aos professores \\ que estão preocupados sua solidariedade. \\ Os pais demonstram aos professores \\ que estão preocupados. Sua solidariedade,
}

iii) duração total da tarefa. Por tratar-se de um experimento ainda sem um número expressivo de participantes, de caráter ainda exploratório, não foi possível obter dados suficientes para fazer uma análise estatística, a exemplo do experimento 1 . No entanto, nada impede a análise preliminar e qualitativa dos dados obtidos até então e a verificação de possíveis direcionamentos dos desempenhos dos grupos, principalmente a partir dos protocolos verbais produzidos no pós-tarefa.

No que diz respeito ao número de correções e a qualidade delas, considerando o número de itens experimentais, 12, multiplicado pelo número de participantes, temos um total de 60 correções a serem efetuadas. Com uma regra de 3 simples, os seguintes dados foram obtidos: o grupo de tradutores manipulou 52 instâncias de itens experimentais, desfazendo com sucesso a ambiguidade de 47 sentenças, resultando numa média de $79 \%$ de acerto. Já o grupo de aprendizes manipulou 43 instâncias de itens experimentais, desfazendo com sucesso a ambiguidade de 34 sentenças, resultando numa média de 57\% de acerto. 


\begin{tabular}{|l|l|l|}
\hline & EXP & INEXP \\
\hline ITENS & 60 & 60 \\
\hline MANIPULAÇÕES & 52 & 43 \\
\hline DESAMBIGUIZAÇÃO & 47 & 34 \\
\hline $\begin{array}{l}\text { DESAMBIGUIZAÇÃO } \\
\text { EQUIVOCADA }\end{array}$ & 3 & 7 \\
\hline $\begin{array}{l}\text { MANIPULAÇÃO } \\
\text { NÃO RELACIONADA }\end{array}$ & 2 & 2 \\
\hline
\end{tabular}

Tabela 1: Manipulação dos itens pelos participantes

Os gráficos abaixo demonstram a duração da tarefa para cada participante de cada grupo e a média de ambos os grupos, tendo o grupo de aprendizes levado em média 7 minutos a mais para a conclusão da tarefa.

$57: 36$

$43: 12$

$28: 48$

$14: 24$

$00: 00$

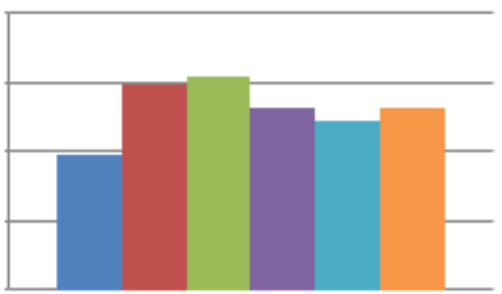

INEXP1

- INEXP2

INEXP3

INEXP4

INEXP5

MÉDIA INEXP

Gráfico 5: Tempo de duração da tarefa para aprendizes

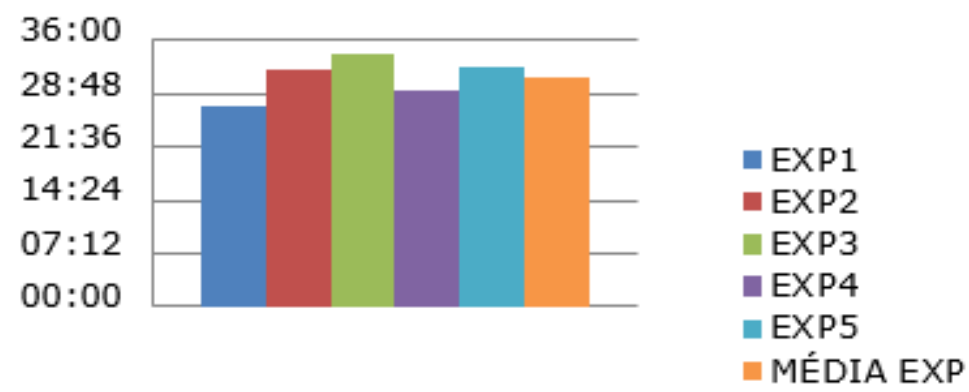

Gráfico 6: Tempo de duração da tarefa para participantes experientes 


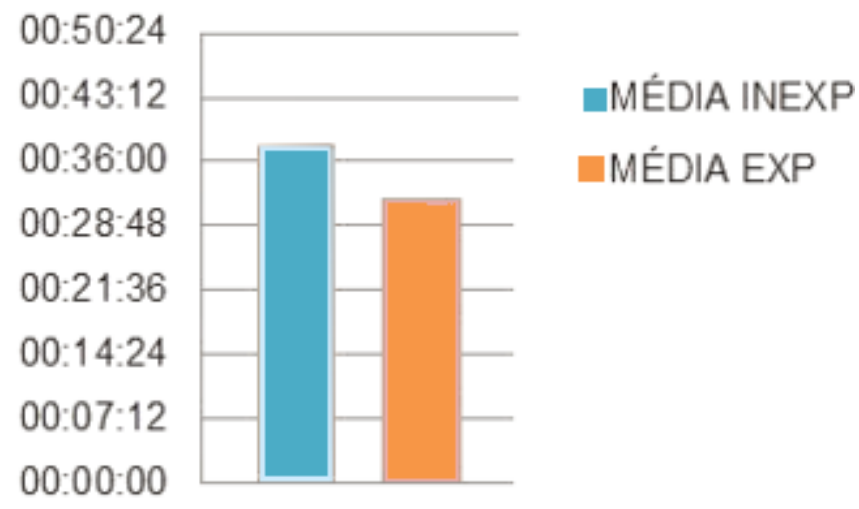

Gráfico 7: Média do tempo de duração da tarefa para os grupos

Como mencionado anteriormente, dado o tamanho da amostra no experimento 2, não é possível fazer generalizações ambiciosas sobre o comportamento de ambos os grupos no que diz respeito aos dados acima, quantidade de alterações e duração da tarefa, todavia, não se pode deixar de notar que os dados apontam para uma superioridade esperada do grupo formado por tradutores experientes sobre o grupo formado por aprendizes.

Ao analisar as tabelas abaixo, onde estão registradas todas as reações aos itens experimentais, é possível notar a emergência de alguns comportamentos que devem ser tratados com maior atenção. 


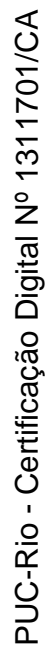
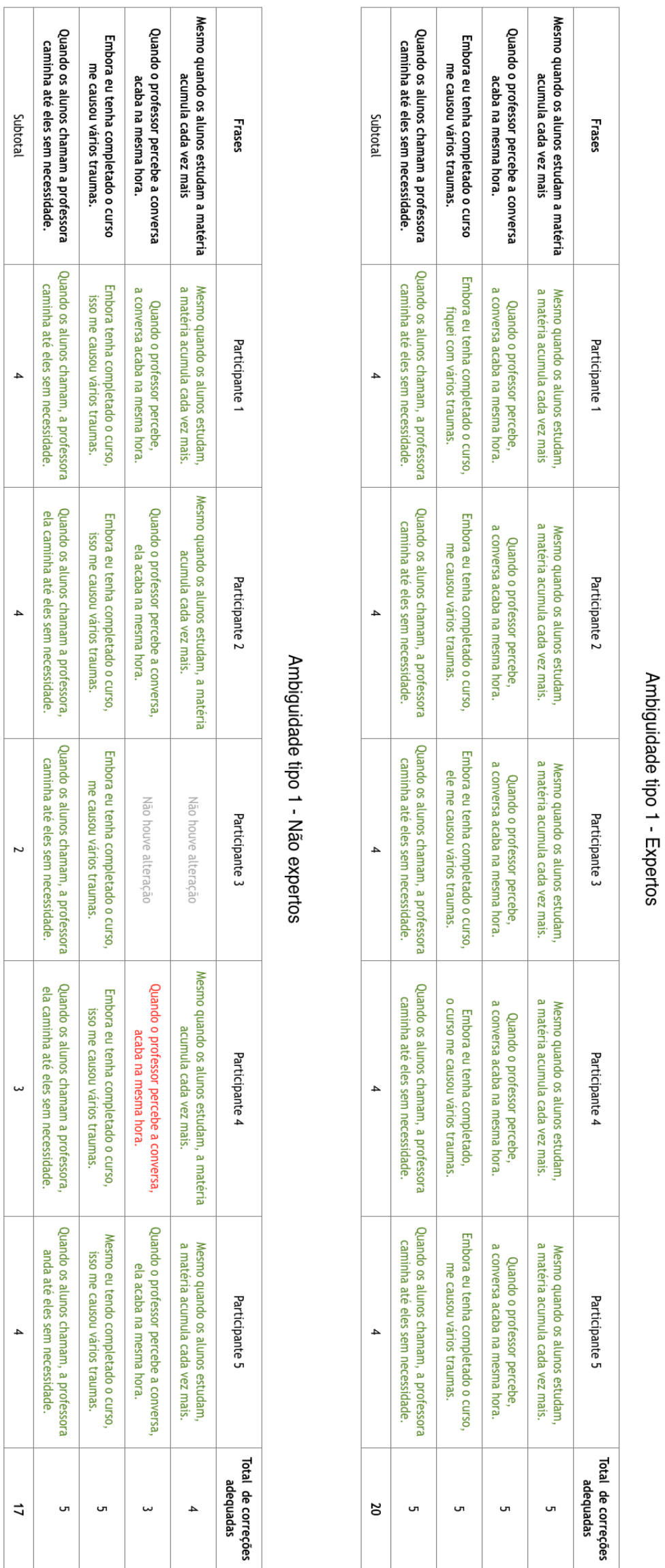

Figura 7: desempenho de expertos e não expertos nos estímulos tipo 1 


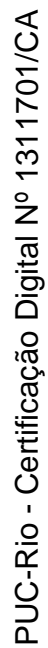

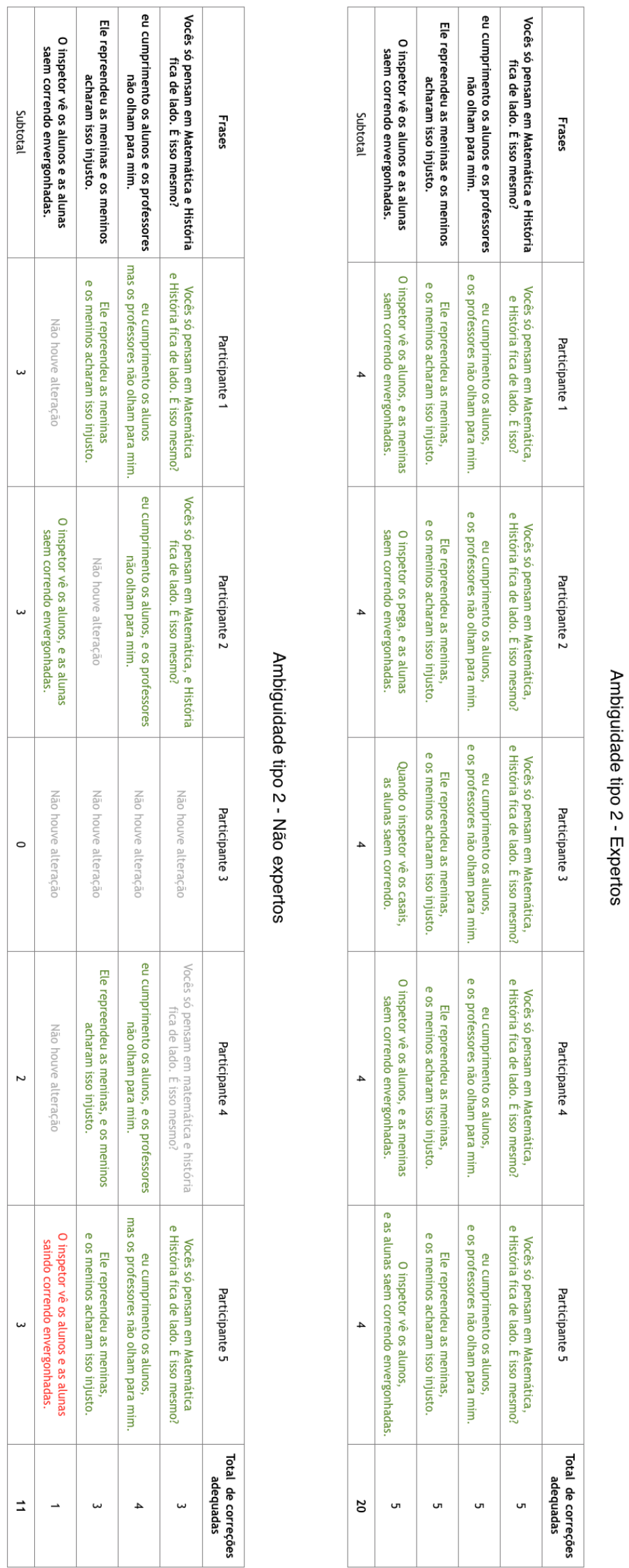

Figura 8: desempenho de expertos e não expertos nos estímulos tipo 2 


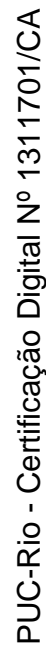

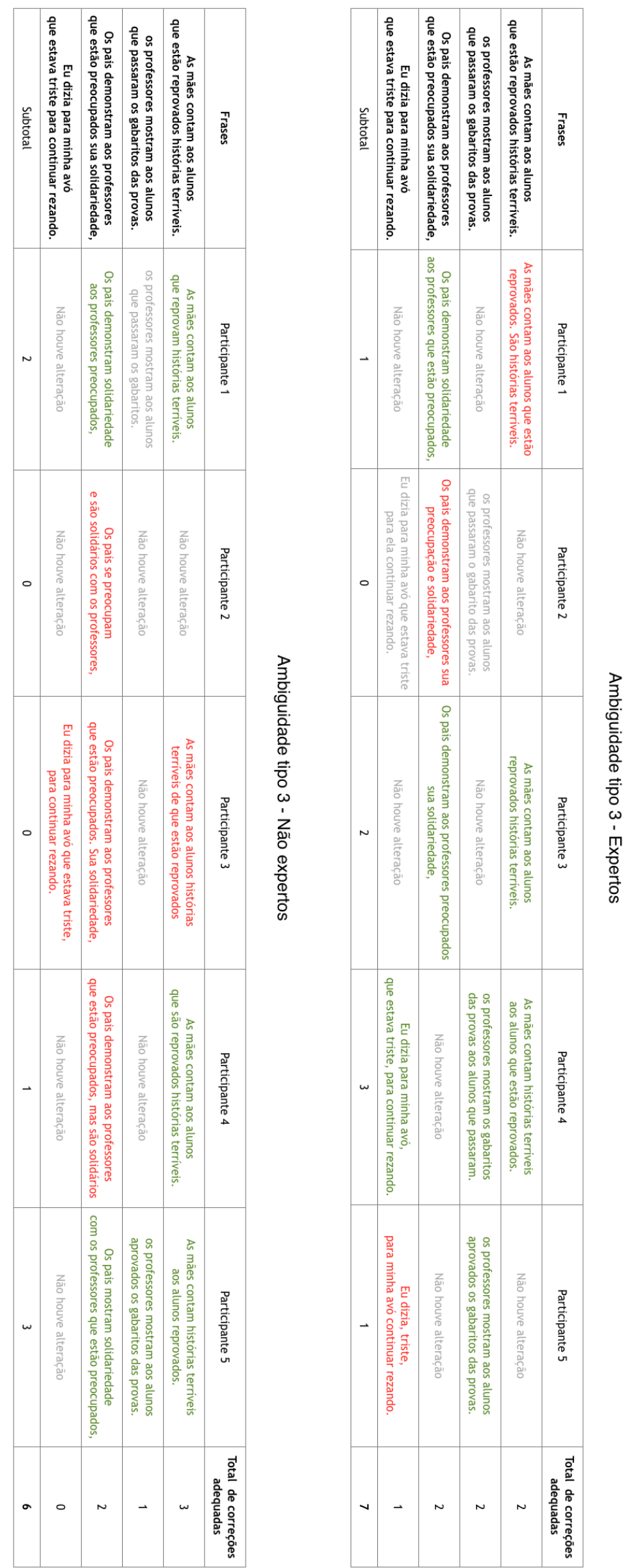

Figura 9: desempenho de expertos e não expertos nos estímulos tipo 3 
O grupo formado por aprendizes apresentou uma tendência ao processamento good enough. Em defesa desse argumento, pode-se dizer que, tendo em vista que o participante manipulou a legenda que continha uma ambiguidade temporária decorrente de uma segmentação ineficiente, ele tenha percebido tal ambiguidade. No entanto, ele não foi capaz de desfazê-la e, com isso, produziu uma representação minimamente satisfatória. Isto pode ser observado, por exemplo, nos comportamentos de 4 de 5 dos participantes deste grupo:

\begin{tabular}{|c|c|c|}
\hline Participante & ESTÍMULO & REVISÃO \\
\hline Inexp 5 & $\begin{array}{l}\text { O inspetor vê os alunos e as alunas } \\
\text { saem correndo envergonhadas. }\end{array}$ & $\begin{array}{l}\text { O inspetor vê os alunos e as alunas } \\
\text { saindo correndo envergonhadas. }\end{array}$ \\
\hline Inexp 2 & $\begin{array}{l}\text { Os pais demonstram aos professores } \\
\text { que estão preocupados sua solidariedade. }\end{array}$ & $\begin{array}{l}\text { Os pais se preocupam } \\
\text { e são solidários com os professores. }\end{array}$ \\
\hline Inexp 4 & $\begin{array}{l}\text { Os pais demonstram aos professores } \\
\text { que estão preocupados sua solidariedade. }\end{array}$ & $\begin{array}{l}\text { Os pais demonstram aos professores } \\
\text { que estão preocupados, mas são solidários. }\end{array}$ \\
\hline Inexp 3 & $\begin{array}{l}\text { As mães contam aos alunos } \\
\text { que estão reprovados histórias terríveis. }\end{array}$ & $\begin{array}{l}\text { As mães contam aos alunos histórias } \\
\text { terríveis de que estão reprovados. }\end{array}$ \\
\hline
\end{tabular}

Tabela 2: Revisões de aprendizes

No primeiro exemplo da tabela acima, podemos ver que o aprendiz 5 manipulou o tempo verbal da sentença, mas não fez nenhuma alteração de ordem ou de pontuação que pudessem desambiguizá-la adequadamente. Ademais, a sentença torna-se agramatical ao permitir a concordância entre "os alunos e as alunas" e "envergonhadas". Já no exemplo produzido pelo participante Inexp 2, apesar do contexto, legendas tanto antes quanto depois do item experimental, que explicita que os únicos preocupados são os professores, percebemos que a compreensão deste participante foi de que os pais são solidários $e$ se preocupam com os professores que, por sua vez, se tornam objeto de ambas as ações na legenda. É importante mencionar que a frase produzida pelo participante satisfaz um critério gramaticalidade, mas falha em representar adequadamente um contexto com relativa proeminência. 
A recomendação para os pais é não contratar esses serviços.

Essa informação consta no comunicado

que o Ministério da Educação envia no começo do ano letivo.

Isso prejudica a dinâmica escolar e fere a legislação vigente.

O professor que faz isso é anti-ético, está agindo ilegalmente

e pode ser punido severamente, inclusive perdendo o direito de dar aulas.

Isso cria um ambiente de desconfiança.

\section{Os pais demonstram aos professores que estão preocupados sua solidariedade,}

pois não denunciam esses esquemas.

A atitude dos pais também poderia ser considerada crime, concorda?

O aprendiz 4, no mesmo item experimental, produziu a seguinte segmentação: "Os pais demonstram aos professores /que estão preocupados, mas são solidários." A reescrita desta frase pelo participante demonstra um equívoco considerável ao atribuir ambas ações aos "pais" e, principalmente, ao inserir uma relação adversativa originalmente inexistente na sentença. Já na sentença produzida pelo participante Inexp 3, “As mães contam aos alunos histórias/terríveis de que estão reprovados", além de uma antinaturalidade da construção "contam histórias de que", que não passa despercebida, o que mais chama a atenção na análise é o equívoco na interpretação ao concluir que as histórias terríveis referem-se às reprovações dos próprios alunos. 
Numa eventual ampliação de amostra, confirmada essa tendência, poder-seá ter a oportunidade de afirmar com maior convicção que os dados corroboram as hipóteses de pesquisas que defendem a existência desse tipo de processamento, como visto no capítulo 3.

Outra tendência digna de atenção nessa fase preliminar de testes diz respeito às estratégias de resolução de ambiguidade empregadas pelo grupo de profissonais. Esse grupo, de modo geral, demonstrou maior refinamento nas suas intervenções, como podemos ver nos exemplos abaixo.

\begin{tabular}{|c|c|}
\hline EXP 1 & $\begin{array}{c}\text { O inspetor vê os alunos, e as meninas } \\
\text { saem correndo envergonhadas. }\end{array}$ \\
\hline EXP 2 & $\begin{array}{l}\text { O inspetor os pega, e as alunas } \\
\text { saem correndo envergonhadas. }\end{array}$ \\
\hline
\end{tabular}

O participante 1 do grupo experiente, por exemplo, além de inserir a vírgula para a separação dos sujeitos, o que seria o suficiente para solucionar a ambiguidade temporária, optou pela troca do nome "alunas" por "meninas", reforçando a diferença entre os objetos da ação do inspetor e otimizando ainda mais a leitura da legenda. O participante 2 do mesmo grupo também demonstrou um comportamento interessante ao utilizar o conteúdo da legenda anterior, "os alunos", para fazer a concordância em "os pega". O participante, durante o protocolo verbal, apresentou, ainda, uma justificativa para sua decisão pela mudança do verbo "ver” para “pegar", no sentido de "flagrar" no contexto, sob o argumento de acreditar que sua escolha conferiria maior naturalidade ao trecho. Pode-se dizer, com base nisso, então, que o participante foi capaz de, numa única legenda, integrar informação de natureza verbal e contextual de uma legenda anterior ao item experimental, desfazer a ambiguidade da legenda e fazer uma alteração de caráter estilístico. Ao justificar suas escolhas de maneira mais organizada e consistente, demonstrando conhecimento declarativo sobre o assunto, os tradutores apresentam um forte indício de que a experiência tradutória em legendagem tem um papel relevante na tarefa. Numa eventual ampliação de amostra, confirmada essa tendência, poder-seá considerar a possibilidade de tomar este tipo de comportamento como ilustrativo 
de desempenho experto em tradução para legendagem, com vistas a sua caracterização para futuras empreitadas na área.

Por último, mas não menos importante, destaco que os estímulos rotulados sob o grupo $\mathrm{C}$, em que a partícula "que" pode ser considerada, durante a leitura ambígua, tanto um pronome relativo quanto uma conjunção integrante que introduz uma oração completiva, foram aqueles em que o desempenho de ambos os grupos foi mais deficitário. Os protocolos verbais, de modo geral, apontaram para uma grande dificuldade dos participantes em lidar com essas sentenças. Em alguns casos, como o do participante 5 do grupo formado por aprendizes ao referir-se ao estímulo "eu dizia para minha avó/que estava triste para continuar rezando", essas sentenças foram consideradas ininteligíveis, o que motivou a abstenção de manipulação do estímulo ou manipulações equivocadas. O status dessas sentenças, sem dúvida, deve ser repensado de forma a esclarecer algumas questões antes de decidir-se por mantê-las no experimento. A primeira delas diz respeito à criação do estímulo e uma possível falha em fazê-lo de maneira adequada ou, até mesmo, na manipulação do contexto ao redor dessas sentenças. Numa eventual ampliação de amostra, confirmada a dificuldade dos participantes com essas sentenças, dever-seá considerar a possibilidade de usar estímulos noves e, reiterando-se a dificuldade em lidar com esses casos de ambiguidade, buscar uma compreensão teórica mais refinada que dê conta da dificuldade encontrada no processamento destas sentenças, principalmente em comparação com aquelas cujo processamento foi descomplicado.

Além da ampliação da amostra do presente experimento, problematizando as questões apresentadas nesta seção de resultados e conclusões, possíveis direcionamentos para pesquisas nesta linha podem vir a incluir outras estruturas sintáticas com vistas ao entendimento de custo de processamento num paradigma com forte apelo naturalista e a carcterização mais ampla das competências específicas de tradutores da área de legendagem. 


\section{Conclusões e considerações finais}

Este trabalho buscou investigar o papel da segmentação textual no desempenho de tradutores para legendagem e na constituição da Competência Tradutória (ALVES E GONÇALVES, 2007) relacionada com os conceitos propotos no âmbito dos Estudos em Expertise e desempenho experto (SHREVE, 2006) por meio do processamento linguístico de estruturas específicas em textos pré-definidos. Considerando o arcabouço oferecido pela Teoria do Garden Path (FRAZIER, 1979; FRAZIER \& FODOR, 1978), na compreensão de sentenças temporariamente ambíguas, seu elevado custo de processamento e consequente desafio que representa para o tradutor experiente e seu desempenho.

Após a introdução desta pesquisa, no capítulo 2, apresentei a Tradução Audiovisual, com ênfase na Legendagem, parte da história da modalidade e os desafios que a caracterizam. Ainda naquele capítulo, abordei a questão da segmentação textual, habilidade fundamental na produção de traduções nesta modalidade, e algumas das discussões que envolvem o tópico, com ênfase nas pesquisas de caráter experimental conduzidas no começo da década de 1990 por d'Ydewalle et al. (1987, 1991 e 1992) e a consequente retomada de interesse no assunto por Perego (2008a, 2008b) quase 20 anos depois. As pesquisas, como conduzidas até então, aparentavam lacunas que foram parte da motivação do presente trabalho. Ao problematizar a questão da segmentação em legendagem com o apoio teórico-conceitual da TGP, inclusive, fica claro que as conclusões de Perego e colaboradores (2010) constituem generalizações perigosas. Os autores, que afirmam que a segmentação textual não impacta a compreensão, restrigem-se a analisar sintagmas nominais, ou seja, ignoram estruturas ambíguas que, a exemplo deste trabalho, vemos que, aparentemente, configuram um desafio para o processamento.

No capítulo 3, apresentei o processo de leitura como caracterizado por Perfetti (2005) e seus principais aspectos para, em seguida, abordar o parser e as hipóteses sobre seu funcionamento. Dentre essas hipóteses, destaquei a Teoria do Garden Path e algumas das discussões sobre seu refinamento, mais especificamente 
a possibilidade de ocorrer um processamento good enough de sentenças ambíguas e a oportunidade de explorá-las experimentalmente de maneira criativa e inovadora na área.

No capítulo 4, introduzimos as pesquisas na área dos Estudos em Expertise e Desempenho Experto e sua relação com os Estudos da Tradução, mais especificamente com pesquisas empírico-experimentais e a investigação do processo tradutório, configurando um ramo em plena ebulição e que mais desperta interesse. Discutimos, ainda, a questão da experiência e seu papel na constituição da expertise e a possibilidade de investigação de habilidades específicas da tradução para legendagem e a relação dessas habilidades com os conceitos de competência e subcompetência tradutória.

A partir das bases supracitadas, propus dois paradigmas para a investigação empírico-experimental dessas habilidades. No capítulo 5, procurei comparar e contrastar os comportamentos de tradutores que podem ser considerados expertos quando esse conceito está intimamente relacionado ao de experiência, ou seja, a despeito da prática deliberada, praticam a tradução e produzem traduções profissionalmente, e aprendizes de tradução (ALVES, 2005). A preocupação com a validade ecológica dos experimentos me fez optar por tarefas reais que fazem parte do cotidiano de legendadores profissionais a fim de testar as habilidades em jogo nesta pesquisa nas condições mais naturais possíves.

No primeiro, o desempenho amplamente superior do grupo experiente em todos os aspectos da tarefa, corroborado pelos dados estatísticos, embora condizentes com as previsões feitas na introdução desta pesquisa, foi, de certa forma, surpreendente. Essa disparidade, no entanto, pode ser entendida como um indicativo de que a tarefa proposta, de fato, proporcionou uma instância de distanciamento entre experts ou profissionais experientes e aprendizes de tradução. O experimento 1 apresentou-se, ainda, bastante informativo sobre o comportamento dos dois grupos analisados nesta pesquisa e forneceu indícios de que nossa hipótese de trabalho deveria ser sustentada, entretanto, um possível fator de dificuldade técnica na execução da tarefa foi relatada por alguns participantes durante os protocolos verbais. Tal dificuldade poderia ser eliminada num experimento futuro a fim de trazer mais confiabilidade aos dados obtidos até aquele momento. 
Sendo assim, o experimento 2 teve como objetivo, além de oferecer uma tarefa, do ponto de vista técnico, ainda mais fácil, prover dados mais refinados que pudessem ser integrados àqueles do experimento 1 para uma compreensão mais ampla do fenômeno em questão. Apesar de uma amostra reduzida de participantes, os dados preliminares do experimento 2 parecem corroborar o que foi visto no experimento 1 no que diz respeito ao desempenho dos participantes. Os protocolos verbais, no entanto, conduzidos de maneira bastante livre ao convidar os participantes a refletirem sobre suas escolhas num contexto sem julgamento e orientar sua atenção de maneira natural aos itens experimentais, permitiram a obtenção de uma riqueza de detalhes que pode e deve ser explorada mais a fundo em outras oportunidades, talvez num desdobramento deste mesmo trabalho.

Conforme discutido no capítulo 3, as sentenças do tipo Garden Path representam um desafio para o processamento durante a leitura. Esse desafio se intensifica num contexto em que a apresentação do texto é efêmera como na legendagem e a possibilidade de releitura, o que poderia facilitar a implementação do processo de reanálise, é limitadíssima, praticamente impossibilitando a compreensão de uma legenda, o que, em última instância, prejudica a experiência de acompanhar uma obra audiovisual legendada e faz o espectador perder interesse. Todavia, quaisquer profissionais que produzam textos, e os tradutores não escapam à regra, estão sujeitos a produzir sentenças do tipo Garden Path ou a se ver numa situação em que é preciso processá-las adequadamente a fim de modificá-las, assim como outras instâncias prejudicias ao processamento ótimo, como problemas de segmentação textual. Dessa forma, torna-se imprescindível que esse profissional tenha o domínio experto sobre esse tipo de estrutura para ser capaz de evitá-las ou corrigi-las de acordo com os diferentes contextos em que isso se faça necessário. $\mathrm{O}$ experimento 2, embora careça de uma amostra mais significativa, indicou que aprendizes, por vezes, aparentemente lançam mão de uma estratégia do tipo good enough ao processar sentenças garden-path, enquanto tradutores experientes, aparentemente, são capazes de não apenas identificar sentenças prejudiciais à compreensão, mas antecipar dificuldades do espectador, colocando-se no lugar dele, o que configura uma habilidade avançada que requer a projeção de expectativas e capacidades de outro indivíduo ao lidar com determinada situação, neste caso, a compreensão de uma sentença. Os participantes experientes, ao 
demonstrarem justificativas consistentes para seu compartamento, parecem ter, de fato, um domínio diferenciado daquele demonstrado por aprendizes. Essa capacidade de revisão de estruturas complexas, explorada longitudinalmente, pode vir a ser considerado um índice de conhecimento experto de considerável relevância para as pesquisas na área.

Quando o domínio supracitado se restringe, na verdade, à segmentação textual, algo tão particular da tradução para legendagem, percebo que as particularidades dessa modalidade, como a própria segmentação, a marcação de legendas e a habilidade de resumo, para citar algumas, compõem um grupo de subcompetências a serem investigadas experimentalmente com o intuito de caracterizar de modo mais amplo o que poderia vir a ser chamado de "competência tradutória em legendagem". Para defender este argumento, cito, ainda na tradução audiovisual, a tradução para dublagem, que prevê, por exemplo, o sincronismo labial, uma competência exclusiva da modalidade.

Nesse sentido, reitero a ideia que permeia este trabalho e digo que empreitadas no sentido de caracterizar diferentes grupos, competências e modalidades de tradução no âmbito dos estudos em expertise e desempenho experto configuram um campo vasto a ser explorado por pesquisadores. Essas empreitadas podem ser ainda mais proveitosas se feitas em caráter interdisciplinar, de modo que as diferentes áreas envolvidas possam vir a gozar dos avanços técnicos e teóricometodológicos umas das outras, num movimento de alimentação mútua de suas bases de conhecimento, da qual pesquisadores e a comunidade científica como um todo só tem a se beneficiar. 


\section{Referências bibliográficas}

ALVES, F. Ritmo cognitivo, meta-função e experiência: parâmetros de análise processual no desempenho de tradutores novatos e experientes. In: ALVES, F; MAGAlHÃES, C. M.; PAGANO, A. S. (Org.). Competência em tradução: cognição e discurso. Belo Horizonte: Ed. UFMG, 2005. p. 109- 169.

ALVES, F. Bases epistemológicas e paradigmáticas para pesquisas empíricoexperimentais sobre competência tradutória: uma reflexão crítica. DELTA. Documentação de Estudos em Linguística Teórica e Aplicada (Online), v. 31, 2015. p. 283-315.

ALVES, F.; GONÇALVES, J. L. V. R. Modelling translator's competence: relevance and expertise under scrutinity. In: GAMBIER, Y.; SCHLESINGER, M.; STOLZE, R. (Ed.). Translation Studies: doubts and directions. Selected papers from the IV Congress of the European Society for Translation Studies. Amsterdam: John Benjamins, 2007. p. 41-55.

ALVES, F., HURTADO ALBIR, A. Cognitive approaches. Handbook of translation studies, 2010. 1: 28-35.

ARAÚJO, Vera Lúcia Santiago; DE ASSIS, Ítalo Alves Pinto. A segmentação na legendagem para surdos e ensurdecidos (LSE) de Amor Eterno Amor: uma análise baseada em corpus. Letras \& Letras, 2014, 30.2: 156-184.

ARAÚJO, V. L. S. . Multimodality in Subtitling for the Deaf and the Hard-ofHearing Education in Brazil. In: Charles Bazerman; Chris Dean; Jessica Early; Karen Lunsford; Suzie Null; Paul Rogers; Amanda Stansell. (Org.). International Advances in Writing Research: Cultures, Places, Measures. 1ed.Anderson, Carolina do Sul, EUA: Parlor Press, 2012, v. 1, p. 61-79.

BELL, R. T. Translation and translating: Theory and practice. Taylor \& Francis, 1991.

BROADBENT, D. E. The effects of noise on behaviour. 1958.

BRYSBAERT, M., MITCHELL, D. C. Modifier attachment in dutch: Deciding between gardenpath, construal and statistical tuning accounts of parsing. In: 
workshop on Computational Models of Human Syntactic Processing held at NIAS, Wassenaar. 1996.

CHAVES, Élida Gama. Legendagem para Surdos e Ensurdecidos: um estudo baseado em corpus da segmentação nas legendas de filmes brasileiros em DVD. Dissertação de mestrado. 2012.

DE BRUYCKER, W., D'YDEWALLE, G. Reading native and foreign language television subtitles in children and adults. In: Radach R., Hyönä J., Deubel H. (Eds.), The mind's eye: cognitive and applied aspects of eye movement research. Amsterdam: Elsevier, 2003. pp.671-684.

CHRISTIANSON, K., HOLLINGWORTH, A., HALLIWELL, J., FERREIRA, F. Thematic roles assigned along the garden-path linger. Cognitive Psychology, 42, 2001. pp. 368-407

CUETOS, F., MITCHELL, D. C. Cross-linguistic differences in parsing: Restrictions on the use of the Late Closure strategy in Spanish. Cognition, 1988. 30.1: 73-105.

DE GROOT, A. D. Het denken van den schaker: een experimenteelpsychologische studie. Noord-Hollandsche Uitgevers Maatschappij, 1946.

DE LINDE, Z., KAY, N. Processing subtitles and film images: Hearing vs deaf viewers. The Translator, 1999a. 5.1: 45-60.

DE LINDE, Z., KAY, N. The Semiotics of Subtitling, Manchester: St. Jerome Publishing. 1999b.

DÍAZ-CINTAS, J. Audiovisual translation in the third millennium. Translation today: Trends and perspectives, 2003. 192-204.

DÍAZ-CINTAS, J. Audiovisual translation comes of age. In: Between Text and Image: Updating Research in Screen Translation. Amsterdam: John Benjamins, 2008. 1-9.

DÍAZ CINTAS, J; Subtitling: Theory, Practice and Research In: The Routledge Handbook of Translation Studies, edited by Carmen Millán e Francesca Bartrina. New York: Routledge. 2013 p. 273-288. 
DÍAZ CINTAS, J. REMAEL, A. Audiovisual translation : subtitling. Manchester : St. Jerome Publishing, 2007.

DINIZ, Nina Soares Lopes. A segmentação em legendagem para surdos e ensurdecidos: um estudo baseado em corpus. Dissertação de mestrado. 2012.

DUNCKER, K., LEES, L. S. On problem-solving. Psychological monographs, 1945. 58.5: i.

D'YDEWALLE, G. Watching subtitled television automatic reading behavior. Communication research, 1991. 18.5: 650-666.

D'YDEWAlle, G., PRAET, C., VERFAILlie, K., VAN RENSBERGEN, J. Watching subtitled television automatic reading behavior. Communication research, 1991, 18(5), pp.650-666.

D'YDEWALLE, G., GIELEN, I. Attention allocation with overlapping sound, image, and text. In: Eye movements and visual cognition (pp. 415-427). 1992. Springer New York.

D'YDEWALLE, G., DE BRUYCKER, W. Eye movements of children and adults while reading television subtitles. European Psychologist, 2007. 12.3: 196-205.

D'YDEWAlLE, G., MUYLle, P., VAN RENSBERGEN, J. Attention shifts in partially redundant information situations. Eye movements and human information processing, 1985. 375-384.

D'YDEWALLE, G., PAVAKANUN, U. Acquisition of a second/foreign language by viewing a television program. In: Psychology of Media in Europe. VS Verlag für Sozialwissenschaften, 1995. p. 51-64.

D'YDEWALLE, G., PAVAKANUN, U. Could enjoying a movie lead to language acquisition?. In: New horizons in media psychology. VS Verlag für Sozialwissenschaften, 1997. p. 145-155.

D'YDEWALLE, G., VAN RENSBERGEN, J., POLLET, J. Reading a message when the same message is available auditorily in another language: The case of subtitling. 1987. 
D'YDEWALLE, G., WARLOP, L., VAN RENSBERGEN, J. Television and attention: differences between younger and older adults in the division of $\begin{array}{lllll}\text { attention over } & \text { different } & \text { sources } & \text { of } & \text { TV }\end{array}$ information. Medienpsychologie, 1, 1989. pp. 42-57.

D'YDEWALLE， G., VAN DE POEL， M. Incidental foreign-language acquisition by children watching subtitled television programs. Journal of Psycholinguistic Research, 28, 1999. pp. 227-244

D'YDEWALLE, G., DE BRUYCKER, W. Eye movements of children and adults while reading television subtitles. European psychologist : the journal for psychology in Europe, 12, 2007. pp.196-205.

D'YDEWALLE， G., PRAET， C., VERFAILLIE， K., VAN RENSBERGEN, J. Watching subtitled television - automatic reading behavior. Communication research, 18 (5) 1991. pp. 650-666.

ERICSSON, K. A. Expert performance and deliberate practice: An updated excerpt from Ericsson (2000). Retrieved July, 2000. 22: 2007.

ERICSSON, K. A. The Cambridge handbook of expertise and expert performance. Cambridge University Press, 2006.

FERREIRA, F., CLIFTON, C. The independence of syntactic processing. Journal of memory and language, 1986. 25.3: 348-368.

FERREIRA, F. The misinterpretation of noncanonical sentences. Cognitive Psychology, 2003. 47:164-203.

FERREIRA, Fernanda; BAILEY, Karl G. D; FERRARO, Vittoria. Good-Enough representations in language comprehension. Current Directions in Psychological Science, 2002. 11:11-5.

FERREIRA, F.; PATSON, N.D. The 'Good Enough' Approach to Language Comprehension. Language and Linguistics Compass, v.1, n.1-2, 2007, p. 71-83. FERNÁNDEZ, Eva M. How might a rapid serial visual presentation of text affect the prosody projected implicitly during silent reading?, 117-154. In Conferências do V Congresso Internacional da Associação Brasileira de Lingüistica. 2007. 
FLORES D'ARCAIS, G. B. 'Syntactic Processing during Reading for comprehension', in Max Coltheart (ed.) Attention and Performance II: The Psychology of Reading, London: Lawrence Erlbaum Associates, 1987, 619-33.

FRAZIER, L., CLIFTON JR, C. Construal. MIT Press. Cambridge, MA, 1996.

FRAZIER, L., FODOR, J.D. The sausage machine: A new two-stage parsing model. Cognition, 1978, 6.4: 291-325.

FRAZIER, Lyn. 'Sentence Processing: A Tutorial Review', in M. Coltheart (ed.) Attention and Performance II: The Psychology of Reading, London: Lawrence Erlbaum Associates, 1987, 119-86.

GAMBIER, Yves; GOTTLIEB, Henrik (ed.). (Multi) media translation: concepts, practices, and research. John Benjamins Publishing, 2001.

GAMBIER, Y. The Position of Audiovisual Translation Studies In: The Routledge

Handbook of Translation Studies, edited by Carmen Millán e Francesca Bartrina. New York: Routledge. 2013 pp. 45-60.

GERLOFF apud DRAFT OF SIREN, S. HAKKARAINEN, K. The cognitive concept of expertise applied to expertise in translation. Across Languages and Cultures, 2002, 3, 1, 71-82.

GIELEN, Ingrid, D'YDEWALLE, Géry. 'Visual and Linguistic Processes in Children with Reading Disabilities', in Roberto Schmid and Daniela Zambarbieri (eds) Oculomotor Control and Cognitive Processes. Normal and Pathological Aspects, Amsterdam \& New York: North-Holland, 1991, 491-502.

GLOBOSAT. Padrões Globosat, versão 3, Rio de Janeiro, arquivo de texto (inédito), 2014.

GONÇALVES, J. L. V. R. O desenvolvimento da competência do tradutor: investigando o processo através de um estudo exploratório-experimental. Tese (Doutorado em Estudos Linguísticos) - Universidade Federal de Minas Gerais. 2003.

GOTTLIEB, G. Individual development and evolution: The genesis of novel behavior. Psychology Press, 2001. 
GRILLO, Virgil; KAWIN, Bruce. 'Reading at the Movies: Subtitles, Silence and the Structure of the Brain' in Post Script: Essays in Film and Humanities, 1981, $1(1): 25: 32$.

GRIMES, T. Mild auditory-visual dissonance in television news may exceed viewer attentional capacity. Human Communication Research, 1991. 18.2: 268298.

IVARSSON, Jan; CAROLL, Mary. Subtitling, Simrishamn (Sweden): TransEdit HB. 1998.

JAKOBSEN A. L. Translation drafting by professional translators and by translation students. Copenhagen studies in language, 2002. 27:191-204.

JAKOBSON, R. On linguistic aspects of translation. On translation, 1959. 3: 3039.

KARAMITROGLOU, F. A proposed set of subtitling standards in Europe. In: Translation Journal, v. 2, n.2, 1998. Periódico virtual sem numeração de páginas, disponível em: http://www.accurapid.com/journal/.

KIRALY, D. C. Pathways to translation: Pedagogy and process. Kent State University Press, 1995.

KOOLSTRA, C. M., BEENTJES, J. W. J. Children's vocabulary acquisition in a foreign language through watching subtitled television programs at home. Educational Technology Research and Development, 1999. 47.1: 51-60.

KOOLSTRA, C. M., PEETERS, A. L., SPINHOF, H. The pros and cons of dubbing and subtitling. European Journal of Communication, 2002. 17.3: 325-354.

KOOLSTRA, C., VAN DERVOORT, T., D'YDEWALLE, G. Lengthening the presentation time of subtitles on television: Effects on children's reading time and recognition. Communications, 24, 1999. pp. 407-422

KOTHARI, B., TAKEDA, J. Same language subtitling for literacy: Small change for colossal gains. Information and communication technology in development, 2000. 176-186. 
KOTHARI, B. Film songs as continuing education: Same language subtitling for literacy. Economic and Political Weekly. 1998. Sep 26:2507-10.

KOTHARI, B. Same Language Subtitling on Indian Television. Redeveloping Communication for Social Change: Theory, Practice, and Power, 2000. p. 135.

LABERGE, D., SAMUELS, S. J. Toward a theory of automatic information processing in reading. Cognitive psychology, 1974. 6.2: 293-323.

LANG, A. The limited capacity model of mediated message processing. Journal of communication. 2000. Mar 1;50(1):46-70.

LOVRIC, N. Implicit prosody in silent reading: relative clause attachment in Croatian. Doctoral Dissertation, City University of New York. 2003.

MAIA, M. A. R.. Reading and Listening to Garden-path PP sentences in Brazilian Portuguese. In: Jorge Campos da Costa ; Vera Wanmacher Pereira. (Org.). Linguagem e Cognição. Porto Alegre: Editora PUCRGS, 2009. p. 290-303.

MARTINEZ, S. L. Tradução para legendas: uma proposta para a formação de profissionais. Rio de Janeiro. Dissertação (Mestrado em Letras Estudos da Linguagem). Pontifícia Universidade Católica do Rio de Janeiro, 2007. MIQUEL-IRIARTE, M; VILARÓ, A; ORERO, P; SERRANO, J; e DELGADO, H: Entitling, a way forward for accessibility, em Eye Tracking in Audiovisual Translation, edited by Elisa Perego: Aracne, 2013, pp. 259-277

O'SULLIVAN, C. Introduction: Multimodality as challenge and resource for translation. Carol O'Sullivan and Caterina Jeffcote. Special issue of JoSTrans, 2013. 20:2-14.

PAGANO, A. S.; ALVES, Fábio; ARAÚJO, Vera Lúcia Santiago . Approaching expertise in subtitling: A pilot experiment. In: Serban, Adriana; Matamala, Anna; Lavaur, Jean-Marc. (Org.). Audiovisual Translation in Close-up. Berna: Peter Lang, 2011, v. , p. 133-160.

PEREGO, E. La traduzione audiovisiva. Carocci, 2005.

PEREGO, E. Towards improved readability. In: Between text and image: updating research in screen translation, 2008a. 78, p.211. 
PEREGO, E. What would we read best. In: Hypotheses and Suggestions for the. 2008b.

PEREGO, E., DEL MISSIER, F., PORTA, M., MOSCONI, M. The Cognitive Effective-ness of Subtitle Processing. Media Psychology, 13 (3), 2010. pp. 243272.

PERFETTI, C. A. Comprehending written language: A blueprint of the reader. The neurocognition of language, 1999. 167-208.

PERFETTI, C. A, LANDI, N., OAKHILL J. The Acquisition of Reading Comprehension Skill. 2005.

PERFETTI, C. A., HART, L. The lexical basis of comprehension skill. 2001.

PERFETTI, C.A., LANDI, N.; OAKHILL, J. The Acquisition of Reading Comprehension Skill. 2005.

PICKERING, M. J., VAN GOMPEL, R. P. G. Syntactic parsing. Handbook of psycholinguistics, 2006. 2: 455-503.

RAJENDRANA, D., DUCHOWSKIB, J., .ANDREW, T., OREROC, P., MARTÍNEZ, J. ROMERO-FRESCO, P. Effects of Text Chunking on Subtitling: A Quantitative and Qualitative Examination. Perspectives: Studies in Translatology Volume 21, Issue 1, 2013. pp. 5-21.

RAYNER, Keith; POLLATSEK, Alexander. 'Eye Movements in Reading: A Tutorial Review', in Max Coltheart (ed.) Attention and Performance II: The Psychology of Reading, London: Lawrence Erlbaum Associates, 1987, 317-61.

RAYNER, K., CARLSON, M., FRAZIER, L. The interaction of syntax and semantics during sentence processing: Eye movements in the analysis of semantically biased sentences. Journal of verbal learning and verbal behavior, 1983. 22.3: $358-374$.

RIBEIRO, A. J. C.. A abordagem Good-Enough e o processamento de frases do português do Brasil. Veredas (UFJF Online), 12 (2):62-75, 2008. 
RIBEIRO, A. J. C. Good-Enough representations of Brazilian Portuguese gardenpath sentences. Poster presented at The 22nd Annual CUNY Conference of Sentence Processing. Davis: University of California, March-2009.

RIBEIRO, A. J. C. Good-Enough comprehension of Brazilian Portuguese Reflexive Absolute Verb sentences. In: Maia, M, França, A. I. Papers in Psycholinguistics. Rio de Janeiro: Imprinta, p. 157-62, 2010.

RIBEIRO, A. J. C. Reanálise parcial de frases garden-path do PB. Apresentado no XXV Encontro Nacional da ANPOLL. Belo Horizonte: UFMG: julho-2010a.

RIBEIRO, A. J. C. Late Closure e Good-Enough no processamento de frases garden-path do português do Brasil: evidências de eyetracking. ReVEL, v. 10, n. 18, 2012. [www.revel.inf.br].

RICHARDSON, D. C., DALE, R., SPIVEY, M. J. Eye movements in language and cognition. Methods in cognitive linguistics, 2007. 18: 323.

ROUT, J. F., PERFETTI, C. A., FAVART, M., MARRON, M. A. 1998. Understanding historical controversies: Students' evaluation and use of documentary evidence. International review of history education, 1998. 2, 95117.

RUNDLE, C. Using subtitles to teach translation. La traduzione multimediale: Quale traduzione per quale testo, 2000. 167-81

SCHOTTER, E.R., RAYNER, K. (2013). Eye movements in reading. In E. Perego (Ed.), Eye Tracking in Audiovisual Translation, 2013. pp. 83-104.

SHREVE, G. M. The deliberate practice: translation and expertise. Journal of Translation Studies, 2006. 9.1: 27-42.

SIREN, S. HAKKARAINEN, K. The cognitive concept of expertise applied to expertise in translation. Across Languages and Cultures, 2002, 3, 1, 71-82.

SOUZA, J. A. S., BAYREUTHER, A. C. (Re)drawing a living map of dubbing - The cases of Germany and Brazil. Extended abstract. 6th International Conference Media for All. 2015. pp. 33-36. 
SPIVEY, M. J., RICHARDSON, D. C., FITNEVA, S. A. Thinking outside the brain: Spatial indices to visual and linguistic information. The interface of language, vision, and action: Eye movements and the visual world, 2004. 161189.

TREISMAN, A., GEFFEN, G. Selective attention and cerebral dominance in perceiving and responding to speech messages. The Quarterly journal of experimental psychology, 1968. 20.2: 139-150.

TRUESWELl, J. C., TANENHAUS, M. K., GARnSEY, S. M. Semantic influences on parsing: Use of thematic role information in syntactic ambiguity resolution. Journal of memory and language, 1994. 33.3: 285.

ULLRICH, C., WALLACH, D., MELIS, E. What is poor man's eye tracking good for. In: 17th Annual Human-Computer Interaction Conference. 2003.

VAN LOMMEL， S., LAENEN， A., D'YDEWALLE， G. Foreign-grammar acquisition while watching subtitled television programs. Psychological Reports, 294: KUL. Laboratory of experimental psychology, Leuven, 2003.

VAN LOMMEL，S., LAENEN，A., D'YDEWALLE，G. Foreign-grammar acquisition while watching subtitled television programmes. British Journal of Educational Psychology, 76, 2006. pp.243-258.

ZAGAR, D., PYNTE, J. RATIVEAU IV, S. Evidence for early closure attachment on first pass reading times in French. The Quarterly Journal of Experimental Psychology: Section A, 1997. 50.2: 421-438.

ZHOU, S. Effects of visual intensity and audiovisual redundancy in bad news. Media Psychology, 2004. 6.3: 237-256. 


\section{Anexos}

Todo o material desta seção assim como aqueles que, por limitações técnicas não estão presentes aqui, como os vídeos utilizados nos experimentos, podem ser encontrados no link http://bit.ly/2eDGHLN.

Modelo de Termo de consentimento livre e esclarecido

PONTIFÍCIA UNIVERSIDADE CATÓLICA DO RIO DE JANEIRO PROGRAMA DE PÓS-GRADUAÇÃO EM ESTUDOS DA LINGUAGEM PPGEL

LAPAL - LABORATÓRIO DE PSICOLINGUÍSTICA E AQUISIÇÃO DA LINGUAGEM

Este termo de consentimento livre e esclarecido pode conter trechos que não estejam claros para seu entendimento. Peça ao pesquisador (a) que explique as informações que você desejar.

\section{Do convite}

Você foi convidado (a) a participar desta pesquisa por atender a pré-requisitos necessários. Se decidir participar desta pesquisa, é importante que você leia as informações contidas neste documento a respeito do estudo e do seu papel na pesquisa. Sua participação não é obrigatória, e, a qualquer momento, você pode desistir de participar e retirar seu consentimento. Sua recusa não trará nenhum prejuízo à relação com o pesquisador ou com a Pontifícia Universidade Católica do Rio de Janeiro. É preciso entender a natureza de sua participação e dar o seu consentimento livre e esclarecido por escrito ao final deste documento. Você poderá fazer todas as perguntas que precisar para entender os objetivos da pesquisa, 
esclarecer dúvidas e inteirar-se dos possíveis benefícios desta empreitada. Você receberá uma cópia desde termo no qual constam as informações relativas à pesquisa bem como os contatos (telefone, e-mail e endereço) dos pesquisadores, por meio dos quais você poderá dirimir dúvidas acerca do projeto e de sua participação. Caso seja de seu interesse, deixe seu nome completo e e-mail ao final deste termo para que possamos enviar a você uma cópia de uma possível publicação referente a esta pesquisa.

\section{Dos pesquisadores}

Esta pesquisa tem como responsáveis a Profa. Dra. Érica dos Santos Rodrigues, Professora Titular do PPGEL, cujo endereço é Rua Marquês de S. Vicente, 225 Ala Kennedy, sala K-121 Gávea - Rio de Janeiro, CEP: 22451-900; +55 (21) 35271297, ericasr@puc-rio.br e o mestrando João Artur da Silva Souza, orientando da professora supracitada, cujo endereço é Rua Itaipava, no 17/402, Jardim Botânico, Rio de Janeiro; 22461-030; +55 (21) 98246-0953, j.artur.gem@ gmail.com.

\section{Do objetivo e da justificativa}

O objetivo deste estudo é entender melhor o processo de criação e formulação de legendas a fim de mapearmos estes processos e, eventualmente, estabelecer diretrizes mais claras para esta atividade tradutória.

\section{Do procedimento}

Se concordar em participar deste estudo, você será solicitado a preencher um breve questionário com dados pessoais, acadêmicos e profissionais e a realizar uma tarefa de segmentação de legendas. O processo se dará com o uso de um computador, onde serão feitas a gravação da tela através do software Camtasia e do movimento ocular do participante, através de uma webcam. Durante a tarefa, o participante vai lidar apenas com o software Genius Subtitler, um editor de legendas. Por último, você será solicitado a fazer um breve relato oral sobre a tarefa. Este relato será gravado e, assim como todo o material coletado durante esta tarefa, será catalogado sob um número de referência, preservando-se a a confidencialidade de seus dados pessoais, e será analisado de acordo com fundamentos teóricos e métodos de análise que orientam esta pesquisa. A duração estimada desta atividade é de $20 \mathrm{~min}$ a $35 \mathrm{~min}$.

\section{Dos desconfortos e riscos}

A coleta de dados ocorrerá numa das salas da sede do Departamento de Letras da PUC-Rio. O local foi escolhido por garantir condições seguras e tranquilas de trabalho. Não há quaisquer riscos à sua integridade física ou emocional. Salientase, no entanto, que esta pesquisa será realizada somente se você se sentir em boas condições físicas e emocionais para realizar as atividades solicitadas.

\section{Dos benefícios esperados}

Esta tarefa poderá ou não trazer benefícios com relação ao desenvolvimento de sua compreensão sobre o processo de tradução e/ou edição de traduções para legendagem. Todavia, as informações obtidas através deste estudo serão de extrema relevância para a compreensão de questões concernentes ao estudo da tradução para legendagem.

\section{Dos custos e reembolsos para o participante}

Sua participação deve ser espontânea e voluntária, haja vista que o Comitê de Ética 
a cuja regulamentação estamos submetidos não permite nenhum tipo de compensação.

\section{Da confidencialidade}

Será garantido sigilo absoluto para assegurar a privacidade de todos os sujeitos participantes quanto aos dados confidenciais envolvidos na pesquisa. Entretanto, o Comitê de Ética em Pesquisa da Pontifícia Universidade Católica do Rio de Janeiro, em casos raros, pode precisar consultar seus registros, e somente sob requisição você poderá ser identificado. Contudo, você nunca será identificado quando o material de seu registro for utilizado, seja para propósitos de publicação científica ou educativa. Assim, ao assinar este Termo de Consentimento Livre e Esclarecido, você autoriza as inspeções de seus registros.

\section{Da declaração de consentimento livre e esclarecido}

$\mathrm{Eu}$, , declaro que tive tempo suficiente para ler e entender as informações acima. Declaro também que fui devidamente informado pelo pesquisador João Artur da Silva Souza, sobre os procedimentos, os desconfortos e riscos envolvidos, os benefícios, o custo/reembolso dos participantes e a confidencialidade da pesquisa. Confirmo que a linguagem técnica utilizada neste documento foi satisfatoriamente esclarecida e que recebi respostas para todas as minhas dúvidas. Declaro ainda que me foi assegurado que posso retirar meu consentimento a qualquer momento, sem que isso leve a qualquer penalidade ou perda de benefícios. Confirmo ainda que recebi uma cópia fidedigna deste Termo de Consentimento Livre e Esclarecido.

Dou meu consentimento de espontânea vontade e sem reservas para participar deste estudo.

Assinatura

do

participante:

Data: __ _ _ I

Eu, João Artur da Silva Souza, RG 12614347-8 DETRAN/RJ, CPF 128720957-21, atesto que expliquei a natureza e o objetivo deste estudo, os possíveis riscos e benefícios da participação na pesquisa. Acredito que o participante recebeu todas as informações necessárias em linguagem adequada e compreensível, e que o participante as compreendeu.

Assinatura

do

pesquisador:

Data: 


\section{TRANSCRIÇÃO DOS PROTOCOLOS VERBAIS}

\section{PARTICIPANTE 1}

a) A dificuldade existe, mas achei a legal fazer a legendagem. Não sabia como era. Não é muito difícil, não. A parte da segmentação é fácil. Os controles são mais complicados, mas fica fácil depois que a gente acostuma. O que atrapalha um pouco é que o texto é sempre diferente, né? E como o texto não é nosso, a gente sempre fica com vontade de mexer na tradução.

b) O ritmo da fala ajuda na hora de criar a legenda. Você sabe direitinho quando é um uma legenda ou outra, o que fica difícil é na hora que acaba o espaço, né? O programa marca ali em vermelhinho, e você tem que decidir como vai ficar.

c) É, era a pontuação que ajudava na hora de separar as linhas, mas sempre tem a questão do espaço, né? Não adianta só a pontuação ficar bonitinha, tem que caber. PARTICIPANTE 2

a) A dificuldade é quando, onde inserir as quebras, de linha, de troca de... Muito difícil. [A tarefa] fácil não foi porque eu nunca fiz isso antes, legendagem, então eu olhava esteticamente aquilo e falei "ah, não parece as do filme que eu vejo", aí eu tentava associar e tentava inserir as quebras. Ficava esteticamente feio e eu tentava mudar, só isso. 
b) A prosódia, o ritmo da fala, e às vezes a vírgula. E alguns advérbios também, eu ficava muito em dúvida, alguns você vai ver que botei junto, outros separados, foi uma coisa meio “onde é que eu ponho?”, trouxe problema.

c) A pontuação ajuda, mas não sei muito bem como. Tem a ver com o ritmo, né ? Então ajuda na segmentação, sim.

\section{PARTICIPANTE 3}

a) $\mathrm{Na}$ verdade eu achei que parece muito mais fácil de fazer... Então não é impossível, mas tem um grau de dificuldade que as pessoas não imaginam que seja, assim, alto. Eu acho que o que foi mais difícil mesmo foi decidir onde cortar a frase de acordo com a pontuação e com a forma como ele falava, essas quebras das pausas e às vezes quebrava numa hora em que ele não dava uma pausa, então ficava meio confuso, assim.

b) Segmentar, organizar em legendas, e a forma como ele estava falando.

c) Achei que a pontuação teve um papel importante.

Teve uma hora que eu esqueci qual era o limite... Não lembrava se por linha... o máximo é 28? Então eu excedi muito o limite. Hehe. Várias vezes. Ah, tá, só quando tem uma linha. Então assim não estaria errado, quando tem 29 ? Ah, então tudo bem, então tá certo. Eu acho que o problema maior foi esse mesmo porque eu não conseguia quebrar isso aqui... e tinha esse ponto no final... Eu não sabia mesmo como resolver essa parte. Eu acho que teve uma frase que eu dividi bastante... aqui, deixa eu ver se eu acho... que era uma frase bem comprida, aí eu tive de... algumas. Ai, não tô achando agora. Agora eu já não lembro se eu mudei isso, se na hora eu consegui mudar... Ah, é isso, essa parte aqui. Tá vendo? Foi uma frase só em três legendas.

\section{PARTICIPANTE 4}

a) Eu achei tranquila. Eu acho que... eu não sei se eu fiz certo, mas eu tentei seguir a lógica e olhei como é que ficava na tela, e parecia que fazia sentido com o que eu já vi. Eu tive dificuldade, tipo... esse eu achei mais fácil que o de teste, porque o cara fala mais pausadamente e aí dá pra cê cortar certinho nas vírgulas e fazer o texto bonitinho. Aí, mais pro final... essa última frase do final é que me pegou. Que ele fala assim "BUT" e aí dá vontade de botar assim: "Mas". E botar o resto junto, mas aí não deixava porque tinha 29 letras. Daí eu tive de dividir e eu não gostei 
muito, mas ficou até melhor distribuído, porque fica estranho uma legenda só com "mas". Hahaha.

b) Eu fui olhando o que ele falava e fui vendo que os cortes estavam bem feitos, assim, na tradução, então deu pra dividir certinho.

c) Teve uma legenda, que agora eu não consigo lembrar qual foi, uma que eu pensei que, se tivesse sido traduzida de outra forma, tipo, daria pra encaixar melhor com a fala dele. Eu queria ter marcado, agora eu não lembro. Eu teria de ouvir de novo pra lembrar.

Eu acho que teve até uma palavra que eu mudei, mas acho que não alterou em nada como eu dividiria, sabe? Tem coisa que eu botaria diferente, mas eu pensei "ah, eu botaria diferente, mas ok, ao mesmo, tem que ser mais simplificado porque, assim, não daria pra colocar uma frase enorme, traduzindo tudo literalmente, não ia dar na tela”. Mas algumas eu acho que poderia trocar só uma palavra, não faria diferença nenhuma e eu acho que poderia ficar melhor. Sei lá.

\section{PARTICIPANTE 5}

a) Foi legal, mas eu achei um pouquinho longo, a parte que é valendo. Porque a gente já faz um outro que é de teste, e aí com mais esse fica um pouquinho longo. Então eu acho que poderia ser um fragmento do filme menor, pra não ficar tão longo assim. É uma das ajudas em pesquisa mais longuinhas que eu já fiz. Isso eu achei um ponto pra falar.

b) Às vezes tinha coisas que eu ouvia e por alguma razão eu achava que não tava igual, ou então tava faltando alguma informação na tradução, não sei, eu achava diferente. Eu não sabia se tava errado... Eu não sabia. Eu tinha um pouco de dificuldade. Talvez é o meu inglês, não sei. Você pode dar uma olhada nisso também.

c) Eu achei que, assim, a parte técnica, apesar de ter aquele vídeo introdutório, é meio complexo. Eu acho que eu tenho facilidade com as coisas tecnológicas, mas pode ser que outras pessoas não tenham tanta, então eu acho que é uma coisa que parece muito simples, mas pode ser um pouquinho complexa pra algumas pessoas, essa coisa de ter que ficar lembrando da quantidade de caracteres, onde é cada coisa, a pessoa pode meio que se perder, então é bom não só mostrar aquele videozinho, mas também fazer aquela parte de mostrar pra pessoa e explicar antes dela começar a fazer na gravação, porque eu acho que é quando ela começar a escrever que vai 
surgir várias duvidazinhas, entendeu? Então eu acho que você tem que ajudar um pouco ela antes, tipo “ó, tá vendo?”, "assim e tal", a pessoa pode ficar meio confusa, eu mesmo fico meio confusa com tudo isso. Eu não sabia nem deletar uma linha do negócio, entendeu? Então eu acho que são essas coisas. Pronto.

Tinha algumas legendas que eu queria deixar tudo num negócio só. Só que, pela limitação do caractere, eu não podia deixar. Eu queria deixar e não podia, aí eu tive que... certos períodos que no texto tavam juntos, era um período só, às vezes eu queria deixar junto, mas na tradução não dava, porque não tinha o caractere, então eu tinha que separar aquele período, entendeu? Eu percebi isso.

A pontuação me influenciou um pouco. Porque, por exemplo, se tinha uma vírgula e uma palavra depois da vírgula, eu tentava não... eu tentava... deixar visível, entendeu? Sei lá, me guiava um pouco, assim. Claro que eu... assim, um período acabava, aí eu não começava outro na mesma linha, entendeu? Um período acabou, então eu ia pro outro e assim eu fazia.

Eu acho que a legenda no vídeo é super importante, é uma das coisas mais importantes. Porque não adianta nada ter o texto, só ali escrever, porque é ali que você vê como que tá ficando. Então você vê: “ah, tá legal”. Entendeu?

\section{PARTICIPANTE 6}

a) O maior problema que eu tenho quando eu tô traduzindo é saber quando exatamente que eu separo o fragmento. Se eu termino com verbo... Se tem um verbo pequeno, tipo "ser", por exemplo, que tá na segunda parte, na segunda legenda... é... eu não sabia se "ser" ficava em baixo, se fica em cima... normalmente são detalhes que passam, ou... o término de legenda sem ponto, tem alguns canais que aceitam, tem alguns que não, mas... não sei se tem uma regra básica pra isso. Algumas palavras que foram omitidas no texto, mas isso já foi clarificado que de repente foi por causa do resumo ou coisa do tipo, então isso foi tranquilo. Teve um momento em que eu fiquei um pouco assustada, porque passou do limite aqui, aí desceu e pareceu que tinha apagado tudo, que tinha começado de novo, aí eu fiquei “epa!”, mas tava tudo certo. Eu não sabia se eu devia prestar atenção em pontuação... digo, acentos e eteceteras... enquanto eu escrevia. Eu só transcrevi como tá, nem prestei atenção nisso.

b) Pontuação gráfica me ajudou certamente. Se tem duas vírgulas, por exemplo, eu gosto de colocar o segmento inteiro junto, não partir ele ao meio, mas é uma 
preferência minha, na verdade. Sei lá, parece que eu tô cortando alguma coisa que deveria ficar junta.

c) O fato dele já estar traduzido, eu estar só transcrevendo... Houve frases que poderiam caber em uma única legenda, mas não couberam por causa de pequenos detalhes, tipo... eu não teria como partir sem deixar o final da legenda com uma preposição ou um artigo, o que, no caso, não é bom, não é certo. Mas aqui, por exemplo... foi um erro, na verdade. Isso aqui deveria estar em baixo. Eu tinha colocado na legenda 6, eu tinha colocado a conjunção "e" no final da legenda, e agora eu passei ela pra parte de baixo.

\section{PARTICIPANTE 7}

a) Bom, eu certamente não achei fácil, porque eu nunca fiz legenda, não sei como é que se trabalha com isso, então, realmente, a única instrução que eu tive aqui foi o programa me dizendo o número de caracteres que eu deveria seguir, então eu sabia mais ou menos o que poderia caber numa cédula ou não. Enfim, a maior dificuldade que eu achei foi justamente se eu me guiava pelo som ou pela sintaxe, porque às vezes ele fala, por exemplo, nessa última aqui, bem aqui no final... Ele fala "mas... ainda não tenho uma resposta". Eu colocaria na mesma cédula, mas eu queria colocar "mas" e o resto embaixo, mas aí não podia colocar porque tem o problema dos caracteres, então eu não podia fazer isso. Então aí você não sabe... por exemplo, você não vai fazer uma cédula só com "mas". Pelo menos pra mim, vendo um filme, isso não faria sentido. Mas, ao mesmo tempo, foi onde ele parou. Então é isso aí que ficou no ar pra mim. Por exemplo, aqui, nessa parte que ele fala "I always have". É uma cédula com um textinho super pequeno. Eu poderia colocar outras coisas, mas como ele parou, eu me senti na obrigação de parar. Porque aí a outra apareceria depois. Mas tem outras que, na minha opinião, estão super poluídas, que eu poderia colocar menos, mas aí o som... eu não posso fazer, porque daí não vai ficar de acordo com o som.

b) Levei em consideração o ritmo da fala e a sintaxe.

c) A pontuação também foi um fator importante. Por exemplo, nesse aqui "o que poderia ter sido de mim se não fosse isso"... Já me leva a parar e fazer outra. Mesmo que na fala ele não pare. Mas teve lugar aqui que eu não fiz, que teve um ponto que começou outra palavra, que ele juntou a palavra e eu me senti na obrigação de juntar também. Deixa eu ver se eu acho. Ah, aqui: "as pessoas dão muita importância a esses sinais". Se eu estivesse escrevendo, eu faria vírgula e colocaria o "mas" na 
outra cédula. Mas ele fala muito rapidinho, "esses sinais BUT", então eu quis colocar nessa aqui porque eu achei que faz mais sentido junto com o som.

\section{PARTICIPANTE 8}

a) Eu acho que não tem dificuldade nenhuma. Eu fiquei com algumas dúvidas sobre separação de linhas, quando pode separar, quando não pode, fora os caracteres, né, óbvio. E algumas coisas eu tive vontade de diminuir, mas não podia, porque o texto já está pronto.

b) Teve esse trecho: "desde pequeno, eu lia música e memorizava imediatamente. Na verdade, li música antes de ler palavras". Eu queria colocar esse "na verdade" lá em cima, porque ele fala logo depois, mas não tem espaço, então eu tive de colocar na de baixo. Pelo ritmo da fala seria na anterior, mas eu acho que isso na verdade poderia sair. Talvez. Não sei.

c) $\mathrm{O}$ que era mais importante pra mim era principalmente o ritmo da fala, mas também não deixar uma linha estranha. Por exemplo, "na verdade li música antes", e aí embaixo, "de ler palavras", eu acho que ficaria estranho. No começo, eu pensei que ia dar "minha mãe foi minha primeira professora". A princípio, eu ia deixar “minha mãe foi minha”, e depois "primeira professora", mas eu acho que o possessivo tem que estar junto. Eu acho que é isso. Eu levei critérios sintáticos em consideração, a não ser quando tinha uma pausa muito grande, que dava pra sentir que a frase tinha de ser quebrada ali, foi isso que eu levei em conta.

\section{PARTICIPANTE 9}

a) Eu não tive nenhuma dificuldade muito grande enquanto eu tava realizando essa tarefa, porque, eu não sei, o jeito que o cara fala é praticamente a divisão que eu tive de fazer na legenda, então foi tranquilo. Não tive grandes dificuldades, não.

b) Eu tomei o cuidado de não deixar preposição no fim da frase e tentar fazer blocos de ideias completas, ao invés de fazer uma segmentação aleatória.

c) A pontuação foi importante porque ela, de certa forma, acompanha a cadência, o jeito que o cara está falando.

Só tive um pouco de dúvida quando eu vi que não ia dar pra dividir um bloco de legendas em duas legendas, com duas linhas, aí eu pensava duas vezes se tá ok mesmo deixar só uma linha mesmo de legenda, ao invés de duas. Fora isso, não, foi tranquilo.

PARTICIPANTE 10 
a) Eu não tive problema, não. Achei fácil. Mas isso só você vai poder dizer, olhando o que eu fiz, né? Eu nunca fiz legenda, mas eu fico prestando atenção em tudo que eu vejo legendado. Eu aprendi muito inglês vendo série legendada. Eu ficava vendo aquelas caixas de temporadas, sabe?

b) Eu ora olhava pro texto, ora ouvia o áudio. Mas depois de um tempo fui indo mais pelo texto, porque estava indo mais rápido. Achei que ficou melhor assim.

c) Eu usei muito a pontuação como base. Se você prestar atenção, ajuda muito. A pontuação, a separação das falas, cada célula da legenda, tá tudo ligado, se você olhar bem.

\section{GRUPO DE LEGENDADORES}

\section{PARTICIPANTE 1}

a) Fácil. Nunca transcrevi de um texto que tinha do lado e ao mesmo tempo assistindo ao vídeo, mas trabalhos com legenda fazem parte do meu dia a dia, sim. b) Em geral foi simples, mas quando você vai botar pra não ultrapassar os caracteres, tem umas frases não ficam perfeitinhas, não são quebradas perfeitas, aí você vai, escreve, depois você para e olha e fala "não, isso aqui não vai ficar legal", aí você tem que voltar algumas vezes, até ficar certinho.

c) Então, no início eu tava olhando mais pro texto, e aí eu tava quebrando mais de acordo com o texto. Mas aí, acho que foi do meio pro final, eu passei a prestar mais atenção no vídeo, aí eu fui prestando atenção mais em como ele falava certinho e fui pensando já quando fosse timear, como ia ficar, aí eu fui trocando. [Olhando pro texto,] eu já tinha uma ideia [de como ia segmentar, por causa da pontuação.]

\section{PARTICIPANTE 2}

a) A parte que eu achei mais complicada foi a divisão da quantidade de caracteres que você podia ter por frase. Porque de alguma maneira, às vezes você visualiza a frase funcionando de uma maneira contínua melhor, e você precisa quebrar ela porque ela não cabe dentro do formato que você tem de colocar, por causa da quantidade de caracteres que você tem de colocar em uma linha. Então eu acho que essa divisão é um pouco problemática.

b) Eu acho que o que eu levei mais em conta foi o ritmo da fala. Tanto que algumas frases do texto que eu podia ter mantido em uma legenda só, eu mantive em legendas separadas. Frases que são curtas, que facilmente caberiam na legenda de 
cima, na anterior ou na seguinte, eu preferi tê-las separadas porque eu achei que cabia melhor no ritmo da fala do personagem.

c) Na verdade... Acho que não [usei nenhum fator do texto para me guiar]. Eu acho que o que mais realmente me guiou foi o áudio. Tanto que algumas vezes eu voltei pra reescrever porque eu começava a escrever e percebia que não estava casando muito bem com o áudio, e aí eu voltava. Eu começava com a segmentação dada pelo texto escrito, e depois voltava ou rearrumava em função do que tava sendo dito, ao invés do que tava escrito. Eu acho que o áudio me ajudou mais, me encaminhou melhor.

\section{PARTICIPANTE 3}

a) Tava bem simples. [Minha maior dificuldade foi] só a configuração do teclado mesmo, porque de resto era tudo muito simples.

b) No caso, o texto. Primeiro eu lia, depois eu ouvia e ia digitando enquanto eu ouvia. [Pelo texto, eu já tinha uma ideia de como seria a segmentação], aí, quando eu não tinha muita certeza, eu ouvia o vídeo, só pra garantir.

c) A pontuação gráfica já mostra que vai ter uma pausa, então você já associa aquilo à uma quebra, uma possível segmentação. Esses fatores estão todos ligados.

\section{PARTICIPANTE 4}

a) Não, eu achei bem simples, bem tranquila.

b) Eu, na verdade, tentei me guiar mais pelo texto e eu sinto que no início desse vídeo pareceu... quer dizer, eu dei sorte de "prever", de certa forma, certo como ia aparecer depois. Eu me guiei mais pelo texto do que pelo próprio vídeo.

c) A pontuação [é um fator importante pra mim]. Acho que em alguns casos [eu conseguia prever o número de caracteres com base no texto], mas em alguns momentos eu tive que voltar depois pra dividir.

\section{PARTICIPANTE 5}

a) Fácil. [Estou acostumado a fazer], sim.

b) Eu acho que primeiro já leio o texto escrito, já tenho uma ideia de como será dividido, aí eu ouço o áudio pra ver se é isso mesmo. Em geral, a maioria das vezes, é. Como isso é uma narração, não é gente falando, na maioria das vezes, casa. Mas, quando não casa, eu mudo aquilo que eu tinha na cabeça.

c) [A pontuação é um fator importante], sim, sempre. E eu já tenho uma noção de quantos caracteres cabem numa linha, duas linhas. 


\section{PARTICIPANTE 6}

a) Moderado. Em algumas coisas eu achei difícil segmentar no mesmo ritmo que ele falava ali, porque aí não batia o mesmo número de caracteres pedidos. $\mathrm{E}$ algumas coisas eu também ficava na dúvida se era melhor segmentar antes do verbo ou depois, em algumas eu tive essa dúvida. E também quando tem um locativo, eu não sabia se era melhor colocar na primeira linha ou na segunda linha.

b) Mais o texto, tentei fazer mais o texto e o ritmo. A aparência da legenda, eu não levei muito em conta não.

c) Pontuação, basicamente [me ajudava a pensar a segmentação]

\section{PARTICIPANTE 7}

a) Achei fácil. Porque o texto já tá ali, você não precisa resumir nem nada, é pra colocar exatamente o que tá ali.

b) Eu me orientei bastante pelo texto, eu já ia dividindo e depois ouvindo. Eu já imaginava como ia ser o vídeo, quando eu lia o texto, as pausas que ele ia fazer. Eu também imaginei que você já fez de um jeito que desse pra segmentar em 32 caracteres cada coisinha.

\section{PARTICIPANTE 8}

a) Achei tranquilo, bem fácil. Faz parte do meu dia a dia, já. Nesse caso, nesse vídeo que o cara fala bem devagar, deu pra ir com bastante tranquilidade. focando mais na estrutura do texto. Tipo... o negócio de spotting interno, de como a frase tá organizada, como fica melhor, pra separar assim.

b) Não precisei pensar assim "ah, se tivesse de marcar o tempo disso ia ter que espremer muito mais nessa legenda assim porque esse cara fala correndo", porque ele fala bem devagar. [O ritmo da fala dele] ajudou bastante.

c) No caso, acabei indo mais pelo texto, já que tem mais pausa na fala dele. Em geral é pela pontuação, pela estrutura das orações e tal. De problema, foi mais porque é um texto num registro mais formal, então tem muita palavra grande que não cabe. [Com base no texto eu conseguia fazer umas inferências sobre a formatação das legendas], sim. O áudio acaba sendo mais uma ajuda, mas o texto já... pelo texto dá pra ver como ficaria melhor de segmentar pra não dificultar a leitura. 


\section{PARTICIPANTE 9}

a) Difícil só respeitar o limite de caracteres.

b) Eu tentava conciliar o texto, a ordem das palavras e as sentenças com o que tinha no vídeo.

c) Não, acho que só o texto é bem informativo. Você segmenta de acordo com as frases mesmo. [A pontuação] ajuda, sim [na segmentação]

\section{PARTICIPANTE 10}

a) Achei bem fácil, pra falar a verdade. [É algo que estou acostumado a fazer], sim.

b) Um pouco de cada [(texto e áudio)], pra falar a verdade. Tendo já o texto fonte, eu já fiquei um pouco influenciado, então eu às vezes até antecipei um pouco o texto, já sabendo que o áudio está para entrar, mas depois eu tentei evitar fazer isso. Mas, sim, foi um pouco de cada, já antecipando um timing na minha cabeça, que eu não tenho certeza se ficou bom, o timing, mas tentei me guiar pelo que era dito, mantendo as regras de spotting, mantendo um aspecto visual bom, evitando linhas muito grandes em cima e muito pequenas embaixo repetidamente, um equilíbrio de tamanho. Tentei seguir bem as regras de legendagem mesmo.

c) Com certeza o fato das frases estarem estarem separadas por vírgula te dá uma noção de que você vai ter alguma pausa, uma entonação da pessoa, já vai dar um indício de quebra. Quando é uma frase, um período muito longo, você já sabe que vai dar umas duas, três legendas, aí já tem de organizar o pensamento pra dividir isso. Às vezes eu tive de voltar pra dividir melhor, porque a pessoa falou um pouco mais devagar, um pouco mais rápido. E, assim, a pontuação ditou bem o meu ritmo na hora de digitar. 